
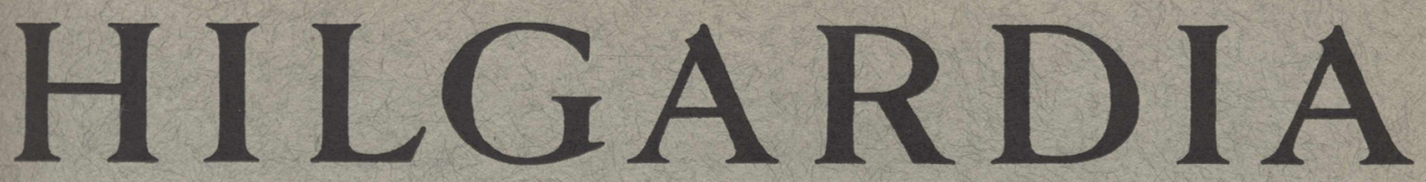

A Journal of Agricultural Science Published by the California Agricultural Experiment Station

\title{
THE RELATIVE EFFECTS OF INBREEDING AND OUTBREEDING ON REPRODUCTION IN THE DOMESTIC FOWL
}

PARTS I-V

PAUL E. BERNIER, LEWIS W. TAYLOR, and C. A. GUNNS

1. SOURCES OF STOCK AND DESICN OF EXPERIMENT

II. FERTILITY

III. HATCHABILITY

IV. EARLY EMBRYONIC GROWTH

V. INTERRELATIONSHIPS OF CHARACTERS STUDIED

UNIVERSITY OF CALIFORNIA • BERKELEY, CALIFORNIA 
This study of the relative effects of inbreeding and outbreeding on reproduction in the domestic fowl is based on two years' observations of triallel matings of hens having an inbred, outbred, and crossbred origin. (P. 529.) Among the many relations established by these observations and reported in the following pages, the data with respect to inbreeding and outbreeding show that:

Fertility was influenced indirectly but not directly by the breeding system. Hens of an inbred origin were definitely less fertile than those of an outbred origin, irrespective of the kind of male to which they were mated. (P. 535.)

Hatchability decreased with inbreeding of outbred females $(F=0$ to $F=.25$ ) but did not decrease with further inbreeding of inbred females. Inbred females showed lower hatchability than outbred females whatever the system of mating, but the difference was not statistically significant. (P. 547.)

Mean blastoderm diameter of unincubated eggs and number of somites in embryos after 38 hours incubation were smaller under inbreeding than outbreeding, and greater under outcrossing than crossbreeding. (P. 560.)

The general fertility-hatchability relationship observed was not altered by origin or genetic relation, or by system of mating. Closely inbred matings of birds with an outbred origin showed a negative correlation between fertility and hatchability which supports the view that fertility is distinct from hatchability. (P. 611.) 


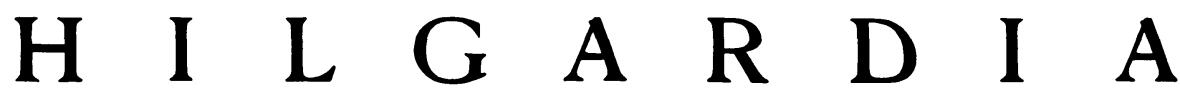

A Journal of Agricultural Science Published by

the California Agricultural Experiment Station

VOL. 20

APRIL, 1951

No. 21

\section{\, \\ The Relative Effects of Inbreeding and Outbreeding on Reproduction in the Domestic Fowl ${ }^{1}$}

\section{PAUL E. BERNIER, ${ }^{2}$ LEWIS W. TAYLOR, ${ }^{3}$ and C. A. GUNNS}

\section{SOURCES OF STOCK AND DESIGN OF EXPERIMENT}

THIS SERIES of papers will report results obtained in an experiment planned to determine some of the effects of inbreeding, outcrossing and crossbreeding on reproduction and on the performance of the offspring resulting from these mating systems. This first paper deals with the preliminary work that led to the development of stocks of chickens for the experiment and to the formulation of an experimental design which would reduce the number of unidentified or unmeasured genetic and nongenetic variables found in experiments previously reported in the literature dealing with the subject of inbreeding. Subsequent papers of this series will deal with experimental results on specific factors of reproduction and progeny performance.

\section{INTRODUCTION}

Poultrymen and investigators have long been concerned with the determination of the advantages and disadvantages involved in the use of different systems of mating poultry. The extensive literature existing on the subject is referred to later in considering the specific characters studied in this experiment. At this point it is sufficient to note that many of the results which have been obtained by different investigators on the effects of inbreeding and outbreeding are not in agreement, whereas conclusions asserting the dangers of inbreeding and the advantages of outbreeding generally have been accepted.

\footnotetext{
${ }^{1}$ Parts I-V received for publication July $19,1949$.

2 Formerly graduate student, Berkeley; now Associate Professor of Poultry Husbandry, Oregon State College.

${ }^{3}$ Professor of Poultry Husbandry and Poultry Husbandman in the Experiment Station, Berkeley.

${ }^{4}$ Principal Laboratory Technician in Poultry Husbandry, Berkeley.
} 
The experiment reported in this series of papers represents an attempt to secure specific information on the effect of mating systems as expressed in characters of economic importance to the poultry industry. In order to overcome some of the difficulties that have beset experiments previously reported in the literature and to reduce the uncontrolled variables affecting the results obtained, an improved design of experiment was used. This design included the following important features :

1. The various kinds of matings were made simultaneously and the products of the matings were treated uniformly throughout;

2. Each breeding individual was mated consecutively under each of the breeding systems compared; and

3. Other characters, particularly those of embryonic development, were added to the list of those usually reported in the literature on the subject.

\section{Definitions}

In order to establish unequivocally the meaning of terms as used in this series of reports, the following definitions are given:

Inbreeding: The mating of individuals which are more closely related to each other than the average relationship within the population concerned (Lush, 1945). The various degrees of inbreeding and of relationship have been measured by coefficients of inbreeding (Wright, 1922,1923 ) calculated for the five generations of ancestors immediately preceding the individual.

Outbreeding: The mating of individuals less closely related to each other than the average relationship within the population concerned (Lush, 1945). Outbreeding within a breed or variety is termed outcrossing, whereas outbreeding involving different breeds is called crossbreeding.

To express the types of matings used in this experiment, the following terminology developed by a committee of the American Society of Animal Production (1940) has been adopted, with certain exceptions noted:

Crossbred: The progeny resulting from the mating of different breeds or, in the case of poultry, different breeds and varieties.

Inbred: The progeny resulting from the mating of closely related animals.

Incross: The progeny resulting from the crossing of individuals of inbred lines $^{5}$ within the same breed, or variety.

Incrossbred: The progeny resulting from the crossing of individuals from inbred lines ${ }^{5}$ of different breeds, or varieties.

Outcross: The mating of relatively unrelated animals within the same breed, or variety.

${ }^{5}$ To qualify as an inbred line an inbreeding coefficient of .375 was suggested by the committee of the American Society of Animal Production. Since then the Federal Trade Commission has issued a ruling that the coefficient must be more than .50. (Trade Practice Rules for the Baby Chick Industry. Promulgated September 15, 1948.) The term incrossbred is, nevertheless, used in this series of papers where the inbred parents had lower coefficients of inbreeding, since the principle of crossing inbred birds from different breeds is comparable. 
Topcross: The mating of a male of a certain family to females of another family of the same breed, or variety.

Topincross: The progeny resulting from the cross of inbred sires on noninbred dams of the same breed, or variety.

Topcrossbred: The progeny resulting from the mating of inbred sires with noninbred dams of different breeds, or varieties.

\section{SOURCES OF STOCK}

All of the stocks used in this experiment were developed at the University poultry plant in Berkeley and complete pedigree records of the birds were available for more than five generations. This flock was free from pullorum disease for several years preceding the beginning of the experiment; no reactors were found in annual pullorum tests made during the course of this work. The following breeding lines were used.

\section{The Small Embryo Line}

This line had its origin in 1934 from stocks originally selected for high and for low hatchability. In a project designed to determine the sources of variation in the size of the unincubated blastoderms (embryos) of freshly laid eggs, it was established that hens varied greatly in the amount of development that had taken place in their fertile eggs before laying. Based on the assumption that this characteristic might be inherited, matings involving inbreeding were begun to develop a small embryo line. Since the characters developed in this line are the subject of study in succeeding papers of this series, a more detailed description of results and their validity obtained previous to this experiment is included here.

Among the factors found to influence the size of the embryo at the time the egg was laid were clutch position and individuality of the hen (Taylor and Gunns, 1935). Apparently hatchability was not correlated with embryo size or with the development of parts of the unincubated chick blastoderm with exception of the amount of overgrowth (Taylor and Gunns, 1939). The latter gave a low positive correlation with hatchability $(0.31 \pm 0.13)$.

That the size of the embryo, as determined by maximum diameter of the blastoderm, was a valid, though somewhat inexact, measure of cell development was established microseopically by cell nucleus counts in each tenth section of eight embryos selected to represent a normal range of sizes. The following data were obtained :

$\begin{array}{cc}\begin{array}{c}\text { Maximum diameter } \\ \mathrm{mm}\end{array} & \text { Number of nuclei } \\ 3.38 & 9,738 \\ 3.47 & 13,334 \\ 3.57 & 10,573 \\ 3.64 & 11,854 \\ 3.71 & 11,356 \\ 3.80 & 14,053 \\ 3.87 & 13,591 \\ 3.92 & 13,430\end{array}$


A correlation of $.67 \pm .16$ for these limited data indicated that the relationship between maximum size and cell number was significant. Limited data also indicated that hens producing large embryos at the unincubated stage tended to produce embryos with a higher number of somites after 38 hours of incubation than the small embryo dams.

In the years between 1934 and the inception of this experiment, the mean blastoderm size of 46 daughters from 21 dams with different characteristic embryo sizes was measured. A low and positive, but nonsignificant, correlation was found to exist between dam and daughter average blastoderm sizes $(.22 \pm .14)$.

In 1940 there were available for use 31 inbred birds of both sexes with an average inbreeding coefficient of .36 and 3 females from an outcross mating of small embryo dams to a nonrelated male; of these $180+$ and $2 \precsim ð$ were used. this line was designated SE.

One of the anticipated advantages of the use of the SE line in this experiment was to determine whether the small embryo character was inherited. Unfortunately, due to reproductive failures in 1940, this line had to be re-

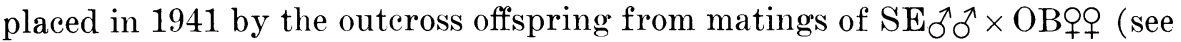
below). The offspring from the OB dams having characteristically small embryos were designated SEOBs and those from dams producing large embryos $\mathrm{SEOBI}$.

\section{The Outbred (Outcross) Stock}

These birds were derived from the production-bred lines of the University flock. No inbreeding was detectable in the five preceding generations of the family of 12 full sisters and two full brothers chosen for this line. This was designated the $\mathrm{OB}$ line; the birds used in 1941 were from $\mathrm{OB} \times \mathrm{OB}$ matings made in 1940 and were designated $\mathrm{OB}^{2}$.

\section{The Crossbred Line}

Preceding this experiment, reciprocal crosses had been made between Columbian Plymouth Rock and Silver Spangled Hamburg chickens. From the $\mathrm{F}_{2}$ generation of these crosses, color segregates for predominantly white and predominantly black plumages were selected to develop two color lines which, with their descendants, were then inbred for several generations. In 1940 the white line was chosen to represent the line of originally crossbred origin and was designated the CB line. Failing to reproduce satisfactorily, this white line was replaced in 1941 by the black line which was designated XB.

\section{DESIGN OF THE EXPERIMENT}

The plan of matings and the resulting ranges of coefficients of inbreeding for the offspring of the matings are given in table 1.

Essentially the same design was used in both years of the experiment. Three sets of males, in most instances full- or half-brothers of the females representing each line, were used to head the breeding pens. The males were rotated from pen to pen after a four-week mating period, thus enabling all females to be mated in turn with each of the three sets of males. A period of two weeks elapsed from the time the males were changed from pen to pen before the new period was started, thus reducing the chances for carrying over fertility from 
the preceding set of males. Since each pen contained females representing each of the lines, in any given period males of each origin were mated to females of every origin used. In other words, the various systems of mating were in operation within each pen at each period, while each female was mated in all of the systems at some period during the year.

TABLE 1

EXPERIMENTAL DESIGN FOLLOWED IN THE 1940 AND 1941 MATINGS 1940 matings

\begin{tabular}{|c|c|c|c|c|c|c|c|c|c|}
\hline & \multicolumn{3}{|c|}{ Pen one } & \multicolumn{3}{|c|}{ Pen two } & \multicolumn{3}{|c|}{ Pen three } \\
\hline Females & $\begin{array}{c}\text { Period } 1 \\
\text { SE } \\
\text { males }\end{array}$ & $\begin{array}{c}\text { Period } 2 \\
\text { OB } \\
\text { males }\end{array}$ & $\begin{array}{c}\text { Period } 3 \\
\text { CB } \\
\text { males }\end{array}$ & $\begin{array}{c}\text { Period } 1 \\
\text { OB } \\
\text { males }\end{array}$ & $\begin{array}{c}\text { Period } 2 \\
\text { males }\end{array}$ & $\begin{array}{c}\text { Period } 3 \\
\text { SE } \\
\text { males }\end{array}$ & $\underset{\text { males }}{\text { Period } 1}$ & $\begin{array}{c}\text { Period } 2 \\
\text { SE } \\
\text { males }\end{array}$ & $\begin{array}{c}\text { Period } 3 \\
\text { OB } \\
\text { males }\end{array}$ \\
\hline SE & $\begin{array}{l}\text { inbred } \\
.20-.51^{*}\end{array}$ & outcross & $\begin{array}{c}\text { crossbred } \\
\text { and } \\
\text { incross- } \\
\text { bred }\end{array}$ & outcross & $\begin{array}{l}\text { crossbred } \\
\text { and } \\
\text { incross- } \\
\text { bred }\end{array}$ & $\begin{array}{l}\text { inbred } \\
.20-.51^{*}\end{array}$ & $\begin{array}{l}\text { crossbred } \\
\text { and } \\
\text { incross- } \\
\text { bred }\end{array}$ & $\begin{array}{l}\text { inbred } \\
.20-.51^{*}\end{array}$ & outcross \\
\hline $\mathrm{OB}$ & $\begin{array}{l}\text { topin- } \\
\text { cross }\end{array}$ & $\begin{array}{c}\text { inbred } \\
.25\end{array}$ & $\begin{array}{l}\text { topcross- } \\
\text { bred }\end{array}$ & $\begin{array}{c}\text { inbred } \\
.25\end{array}$ & $\begin{array}{l}\text { topcross- } \\
\text { bred }\end{array}$ & $\begin{array}{l}\text { topin- } \\
\text { cross }\end{array}$ & $\begin{array}{l}\text { topcross- } \\
\text { bred }\end{array}$ & $\begin{array}{l}\text { topin- } \\
\text { cross }\end{array}$ & $\begin{array}{c}\text { inbred } \\
.25\end{array}$ \\
\hline \multicolumn{10}{|c|}{1941 matings } \\
\hline \multirow{2}{*}{ Females } & \multicolumn{3}{|c|}{ Pen one } & \multicolumn{3}{|c|}{ Pen two } & \multicolumn{3}{|c|}{ Pen three } \\
\hline & $\begin{array}{c}\text { Period } 1 \\
\text { SEOBs } \\
\text { males }\end{array}$ & $\begin{array}{c}\text { Period } 2 \\
\text { OB2 } \\
\text { males }\end{array}$ & $\begin{array}{c}\text { Period } 3 \\
\text { XB } \\
\text { males }\end{array}$ & $\begin{array}{c}\text { Period } 1 \\
\text { OB2 } \\
\text { males }\end{array}$ & $\underset{\text { males }}{\text { Period } 2}$ & $\begin{array}{c}\text { Period } 3 \\
\text { SEOBs } \\
\text { males }\end{array}$ & $\underset{\text { males }}{\text { Period } 1}$ & $\begin{array}{c}\text { Period } 2 \\
\text { SEOBs } \\
\text { males }\end{array}$ & $\begin{array}{c}\text { Period } 3 \\
\text { OB2 } \\
\text { males }\end{array}$ \\
\hline SEOBs & $\begin{array}{c}\text { inbred } \\
.3350\end{array}$ & $\begin{array}{c}\text { inbred } \\
.1250\end{array}$ & $\begin{array}{l}\text { topcross- } \\
\text { bred }\end{array}$ & $\begin{array}{c}\text { inbred } \\
.1250\end{array}$ & $\begin{array}{l}\text { topcross- } \\
\text { bred }\end{array}$ & $\begin{array}{c}\text { inbred } \\
.3350\end{array}$ & $\begin{array}{c}\text { topcross- } \\
\text { bred }\end{array}$ & $\begin{array}{c}\text { inbred } \\
.3350\end{array}$ & $\begin{array}{c}\text { inbred } \\
.1250\end{array}$ \\
\hline $\mathrm{XB}$ & $\begin{array}{l}\text { cross- } \\
\text { bred }\end{array}$ & $\begin{array}{l}\text { incross- } \\
\text { bred }\end{array}$ & $\begin{array}{l}\text { inbred } \\
.16-.30^{*}\end{array}$ & $\begin{array}{l}\text { incross- } \\
\text { bred }\end{array}$ & $\begin{array}{l}\text { inbred } \\
.16-.30^{*}\end{array}$ & $\begin{array}{l}\text { cross- } \\
\text { bred }\end{array}$ & $\begin{array}{l}\text { inbred } \\
.16-.30^{*}\end{array}$ & $\begin{array}{l}\text { cross- } \\
\text { bred }\end{array}$ & $\begin{array}{c}\text { incross- } \\
\text { bred }\end{array}$ \\
\hline
\end{tabular}

* Figures separated by - refer to range in coefficients of inbreeding of progeny.

This triallel mating design was conceived to have distinct advantages for detecting variability of environmental as well as genetic origin in the data obtained, besides being very well suited for the methods of statistical analysis employed.

\section{Care of Stock and Collection of Data}

So far as possible identical conditions were provided for mated birds and their offspring. The same breeding and rearing rations were used throughout the experiment. The eggs from each hen were identified by trapping and the approximate hour of the laying of the egg was recorded. Clutch position for 
each egg was obtained from the total record of the bird's production. After each trapping, eggs were gathered and put in an icebox at approximately $45^{\circ}$ F so that development of the embryo would not be prolonged by high environmental temperatures. The eggs were weighed on the morning of the next day and either used for observation of blastoderm size or returned to the icebox.

The following schedule was set for the utilization of the eggs produced: Monday and Wednesday for microscopically determining blastoderm size after fixation, sectioning and staining; Thursday and Sunday for 38 hours of incubation and determination of the number of somites in the embryo: Tuesday, Friday and Saturday for full-term incubation and determination of hatchability. Eggs were incubated up to the 18-day stage in a forced-draft machine, then transferred in pedigree sacks to a natural-draft machine for hatching. The chicks from each hatch were brooded and reared together. Production data were taken on birds housed together in the same series of pens and fed the same rations.

Data available from this experiment included time of laying, clutch position of the egg, the time interval between successive eggs, egg weight, fertility, unincubated blastoderm size, number of somites after 38 hours of incubation, hatchability, rate of growth of chicks reared, and egg production and mortality of females to 18 months of age.

\section{SUMMARY}

The design of a triallel system of matings involving inbreeding, outcrossing and crossbreeding is presented and the origins and characters of the three lines of stocks used in the experiment are described.

\section{ACKNOWLEDGMENT}

The writers are indebted to Dr. I. Michael Lerner for valuable suggestions made during the planning of this experiment and in the application of the statistical methods employed in the analysis of data obtained in this paper and the subsequent reports of this series. 


\title{
The Relative Effects of Inbreeding and Outbreeding on Reproduction in the Domestic Fowl
}

\author{
PAUL E. BERNIER, LEWIS W. TAYLOR, \\ and C. A. GUNNS
}

\section{FERTILITY}

VARIATION IN THE FERTILITY of eggs has been attributed to the individuality of the breeding males and females as well as to many environmental factors (Parker, McKenzie and Kempster, 1942). Investigations made to establish whether or not variations in fertility have a hereditary basis have given negative results. Jull (1935) is the only investigator to have reported a low but significant coefficient of correlation of $.19 \pm .05$ between the fertility of dams and that of their daughters. Inbreeding has been observed to result in a decrease in fertility by Dryden (1915, 1916), Goodale (1927), Hays (1924, 1929 ), Schleinitz (1925), Dunkerley (1931), Jull (1930, 1933), the Northern Sub-committee (1934) and Knox (1946) while Cole and Halpin (1916), Waters and Lambert (1935, 1936a, $b, c)$, and Wilson (1948) observed no change in fertility following inbreeding.

\section{Materials and Methods}

All the eggs laid by the individual birds throughout the three different periods within each of the two years were used to determine fertility. The eggs used to measure hatchability were candled during the seventh day of incubation and the infertile eggs were removed, opened and examined to check if they were actually infertile. The eggs used to measure embryo size after incubation for 38 hours permitted the easiest determination of fertility as they were all opened at that time. Finally, the eggs used for measuring the size of the blastoderm in the unincubated eggs could also be classified easily as fertile or infertile by the size and the structure of the blastodisc. In doubtful cases the eggs were considered as fertile until certainty could be obtained after fixation, sectioning, staining, and microscopic examination.

\section{Analysis of Observations}

The data available on fertility are summarized in table 2 . The weighted average fertility is the statistic $\bar{p}$ calculated by the method outlined by Hendricks (1935). It is an estimate of the average fertility of the eggs produced by a given group of birds and is thus a weighted average. This method of analysis has the disadvantage of necessitating calculation of new sums of squares for each classification in the analysis of variance. These sums of squares are there.fore nonadditive and preclude a multiple classification scheme as well as an analysis of covariance. Another method of analysis was also used as stated 
later. It consisted of converting the percentages into angles which were then used in a standard analysis of variance. The difference in fertility between years is significant and for this reason as well as the fact that different birds were used the data of each year were analyzed separately.

\section{Incidence of Completely Infertile Matings}

In 1940 , out of a total of 85 matings, 23 were classified as completely infertile, while in 1941 only one mating out of a total of 121 was completely infertile. A statistical test gave evidence of heterogeneity in the distribution of infertile matings in the two years. The high incidence of infertile matings observed in 1940 could have entirely disrupted the picture of fertility in that

TABLE 2

DATA AVAILABLE ON FERTILITY

\begin{tabular}{|c|c|c|c|c|c|c|c|}
\hline \multirow{2}{*}{ Year } & \multicolumn{2}{|c|}{ Number of: } & \multicolumn{2}{|c|}{ Number of eggs } & \multirow{2}{*}{$\begin{array}{l}\text { Number of } \\
\text { fertile eggs }\end{array}$} & \multirow{2}{*}{$\begin{array}{l}\text { Average } \\
\text { fertility }\end{array}$} & \multirow{2}{*}{$\begin{array}{c}\text { Weighted } \\
\text { average }(\bar{p}) \mathrm{SE}\end{array}$} \\
\hline & Birds & Matings & Total & $\begin{array}{c}\text { Per } \\
\text { mating }\end{array}$ & & & \\
\hline 1940. & 33 & 85 & 1510 & 17.8 & 873 & .5781 & $.5323 \pm .0464$ \\
\hline 1941. & 43 & 121 & 1769 & 14.6 & 1573 & .8892 & $.8791 \pm .0185$ \\
\hline Both years.. & 76 & 206 & 3279 & 15.9 & 2446 & .7460 & \\
\hline
\end{tabular}

year and for this reason it was deemed advisable to make two separate analyses of the data obtained in that year; one analysis using all the matings, fertile as well as infertile, and the other using only the fertile matings.

The incidence of infertile matings in 1940 was studied within periods, origins of males, origins of females, mating systems, and also rates of production. The results of these studies are presented in table 3 together with the results of the tests of heterogeneity of the frequencies of infertile matings in the various classifications. These tests of heterogeneity reveal that two classifications, origins of males and origins of females, show evidence of heterogeneity in the incidence of infertile matings. The other three classifications (periods, systems of mating, and rates of production) show that infertile matings occurred at random within them. Apparently complete infertility is thus largely accounted for by the constitution of the birds mated. Examination of the results obtained with the different origins of females shows that the SE and the CB lines are the only ones in which infertile matings occurred and it is interesting to note that these two groups of females have an inbred origin. The inbred females, SE and CB, particularly the SE females, could have been ignored more frequently by the males or were possibly less sexually receptive than the $\mathrm{OB}$ females. It is also probable that certain conditions associated with the SE and the CB females, possibly conditions in their oviduct, did not permit the ascension of spermatozoa to the infundibulum. Support for the latter tentative hypothesis comes from observations on attempted artificial insemination of a number of completely infertile SE females; these birds remained infertile. These observations would eliminate sexual inactivity on the 
part of the males and also sexual unreceptivity on the part of the females. Decreased viability of the sperm is also eliminated since the $O B$ females mated with the same males proved fertile. The most logical assumptions are thus that oviducal conditions did not permit survival of the sperm, that the

TABLE 3

DISTRIBUTION OF THE INFERTILE MATINGS IN 1940 ACCORDING TO PERIODS, ORIGINS OF MALES, ORIGINS OF FEMALES,

SYSTEMS OF MATING, AND RATE OF PRODUCTION, TOGETHER WITH TESTS OF HETEROGENEITY OF THE FREQUENCIES

\begin{tabular}{|c|c|c|c|c|c|}
\hline Classification & $\begin{array}{l}\text { Infertile } \\
\text { matings }\end{array}$ & $\begin{array}{l}\text { Fertile } \\
\text { matings }\end{array}$ & Total & $\chi^{2}$ & $P$ \\
\hline \multicolumn{6}{|l|}{ Periods } \\
\hline $1 \ldots \ldots$ & 7 & 24 & 31 & & \\
\hline 2. & 6 & 23 & 29 & & \\
\hline $3 \ldots \ldots$ & 10 & 15 & 25 & & \\
\hline Total. . & 23 & 62 & 85 & 3.02 & $.2-.3$ \\
\hline \multicolumn{6}{|l|}{ Origins of males } \\
\hline SE. . . . . $\ldots \ldots$ & 13 & 18 & 31 & & \\
\hline OB............ & 7 & 20 & 27 & & \\
\hline CB........... & 3 & 24 & 27 & & \\
\hline Total.... & 23 & 62 & 85 & 6.99 & $.02-.05$ \\
\hline \multicolumn{6}{|l|}{ Origins of females } \\
\hline SE............ & 17 & 20 & 37 & & \\
\hline OB. $\ldots \ldots \ldots \ldots$ & 0 & 30 & 30 & & \\
\hline $\mathrm{CB}\left(\mathrm{n}_{1}, \ldots\right.$ & 6 & 12 & 18 & & \\
\hline Total... & 23 & 62 & 85 & 18.18 & .001 \\
\hline \multicolumn{6}{|l|}{ Systems of mating } \\
\hline Inbreeding........ & 10 & 17 & 27 & & \\
\hline Outbreeding..... & 6 & 17 & 23 & & \\
\hline Crossbreeding. & 7 & 28 & 35 & & \\
\hline Total..... & 23 & 62 & 85 & 2.25 & $.3-.5$ \\
\hline \multicolumn{6}{|l|}{ Rate of production } \\
\hline Less than 18 eggs or median... & 16 & 31 & 47 & & \\
\hline More than 18 eggs or median. . & 7 & 31 & 38 & & \\
\hline Total..... & 23 & 62 & 85 & 1.86 & $.1-.2$ \\
\hline
\end{tabular}

eggs had a constitution that did not permit fertilization, or even that the eggs were fertilized but the zygotes died so early that it was practically impossible to determine whether or not they were fertilized.

\section{Analysis of Variation in Fertility}

The data available in each year for all matings and for the fertile matings only in 1940 were analyzed separately. These data were arranged according to periods, origins of males, origins of females and systems of mating as presented in tables 4,5 , and 6 . 


\section{TABLE 4}

\section{DATA ON FERTILITY FOR ALL MATINGS IN 1940 CLASSIFIED ACCORDING TO PERIODS, ORIGINS OF MALES, ORIGINS OF FEMALES AND SYSTEMS OF MATING}

\begin{tabular}{l|c|c|c|c|c}
\hline \multicolumn{1}{c}{ Classification } & $\begin{array}{c}\text { Number } \\
\text { of } \\
\text { matings }\end{array}$ & $\begin{array}{c}\text { Number } \\
\text { of } \\
\text { eggs }\end{array}$ & $\begin{array}{c}\text { Number } \\
\text { of fertile } \\
\text { eggs }\end{array}$ & $\begin{array}{c}\text { Unweighted } \\
\text { average } \\
\text { fertility }\end{array}$ & $\begin{array}{c}\text { Weighted } \\
\text { average }(\bar{p}) \\
\text { fertility }\end{array}$ \\
\hline and SE
\end{tabular}

TABLE 5

DATA ON FERTILITY FOR FERTILE MATINGS ONLY IN 1940 CLASSIFIED ACCORDING TO PERIODS, ORIGINS OF MALES, ORIGINS OF FEMALES AND SYSTEMS OF MATING

\begin{tabular}{|c|c|c|c|c|c|}
\hline Classification & $\begin{array}{c}\text { Number } \\
\text { of } \\
\text { matings }\end{array}$ & $\begin{array}{c}\text { Number } \\
\text { of } \\
\text { eggs }\end{array}$ & $\begin{array}{l}\text { Number } \\
\text { of fertile } \\
\text { eggs }\end{array}$ & $\begin{array}{l}\text { Unweighted } \\
\text { average } \\
\text { fertility }\end{array}$ & $\begin{array}{c}\text { Weighted } \\
\text { average }(p) \\
\text { fertility and SE }\end{array}$ \\
\hline \multicolumn{6}{|l|}{ Periods } \\
\hline $1 \ldots \ldots$ & 24 & 410 & 361 & .8561 & $.8597 \pm .0479$ \\
\hline $2 \ldots \ldots \ldots$ & 23 & 457 & 336 & .6975 & $.6987 \pm .0768$ \\
\hline$\ldots \ldots \ldots \ldots \ldots \ldots$ & 15 & 306 & 176 & .5627 & $.5636 \pm .1098$ \\
\hline \multicolumn{6}{|l|}{ Origins of males } \\
\hline SE.......... & 18 & 362 & 292 & .7932 & $.7929 \pm .0668$ \\
\hline OB $\ldots \ldots \ldots$ & 20 & 351 & 258 & .6963 & $.6999 \pm .0736$ \\
\hline CB... & 24 & 460 & 323 & .7012 & $.7011 \pm .0742$ \\
\hline \multicolumn{6}{|l|}{ Origins of females } \\
\hline SE........... & 20 & 332 & 149 & .4352 & $.4363 \pm .0803$ \\
\hline OB....... & 30 & 664 & 560 & .8443 & $.8481 \pm .0423$ \\
\hline $\mathrm{CB} \ldots \ldots \ldots \ldots \ldots \ldots \ldots \ldots$ & 12 & 177 & 164 & .9063 & $9167 \pm .0 \varepsilon 05$ \\
\hline \multicolumn{6}{|l|}{ Systems of mating } \\
\hline Inbreeding. ....... & 17 & 320 & 230 & .7227 & $.7223 \pm .0733$ \\
\hline 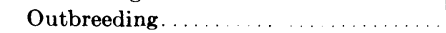 & 17 & 334 & 264 & .7154 & $.7199 \pm .0850$ \\
\hline Crossbreeding $\ldots \ldots \ldots \ldots \ldots \ldots$ & 28 & 519 & 379 & .7350 & $.7357 \pm .0654$ \\
\hline All matings. . & 62 & 1173 & 873 & .7263 & $.7280 \pm .0419$ \\
\hline
\end{tabular}


The periods in the two years did not correspond in dates. In 1940, period 1 extended from February 21 to March 17, period 2 from April 2 to April 28, and period 3 from May 14 to June 9. In 1941, period 1 extended from January 1 to February 19, period 2 from March 6 to April 7, and period 3 from April 22 to May 14. In both years, the periods extended over five months; each consisted of 25 days with an interval of 14 days between consecutive periods.

TABLE 6

DATA ON FERTILITY FOR ALL MATINGS IN 1941 CLASSIFIED ACCORDING TO PERIODS, ORIGINS OF MALES, ORIGINS OF FEMALES, INBREEDING AND CROSSBREEDING, AND DIFFERENT LEVELS OF INBREEDING

\begin{tabular}{c|c|c|c|c|c}
\hline \multicolumn{1}{c|}{ Classification } & $\begin{array}{c}\text { Number } \\
\text { of } \\
\text { matings }\end{array}$ & $\begin{array}{c}\text { Number } \\
\text { of } \\
\text { eggs }\end{array}$ & $\begin{array}{c}\text { Number } \\
\text { of fertile } \\
\text { eggs }\end{array}$ & $\begin{array}{c}\text { Unweighted } \\
\text { average } \\
\text { fertility }\end{array}$ & $\begin{array}{c}\text { Weighted } \\
\text { average }(\bar{p}) \\
\text { fertility }\end{array}$ \\
\hline and SE
\end{tabular}

Periods, origins of males, origins of females and systems of mating all appear to have influenced fertility though not all to the same degree in the two years. An analysis of variance of the weighted averages $(\bar{p})$ has given the results reported in tables 7, 8, and 9 for all matings in 1940, fertile matings only in 1940 and all matings in 1941 respectively.

The analysis shows that the variations between periods are significant only within 1940, and whether all matings or only the fertile matings are taken into consideration. The variations in fertility between periods in 1940 are thus not explained by the varied incidence of completely infertile matings as already demonstrated by the test of heterogeneity of the distribution of infertile matings in table 3 . The variations in fertility between periods in 1941 are not statistically significant although a slight decrease was noted in the third period. The earlier termination of the experiment in 1941 may 
explain the lack of significant differences between periods in that year. The general trend is a decrease in fertility as the hatching season progressed. In the two years the trend is an increase in fertility in February as compared to January, a decrease in April as compared to March, and a decrease in June as compared to May.

TABLE 7

ANALYSIS OF VARIANCE OF THE DATA ON FERTILITY FOR ALL MATINGS IN 1940 USING WEIGHTED AVERAGES $(\bar{p})$

\begin{tabular}{|c|c|c|c|c|}
\hline Source of variation & $\begin{array}{l}\text { Degrees of } \\
\text { freedom }\end{array}$ & $\begin{array}{l}\text { Sums of } \\
\text { squares }\end{array}$ & $\begin{array}{l}\text { Mean } \\
\text { square }\end{array}$ & $F^{*}$ \\
\hline Between periods......... & 2 & 8.77 & 4.385 & 4.36 \\
\hline Within periods. $\ldots \ldots \ldots \ldots \ldots \ldots \ldots \ldots \ldots \ldots \ldots \ldots \ldots \ldots$ & 82 & 82.41 & 1.005 & \\
\hline Between origins of males...... & 2 & 2.10 & 1.05 & 1.05 \\
\hline Within origins of males...... & 82 & 82.21 & 1.00 & \\
\hline Between origins of females.................... & 2 & 76.93 & 38.46 & 38.08 \\
\hline Within origins of females. . . . . . . . . . . . . . . . & 82 & 82.74 & 1.01 & \\
\hline Between systems of mating. . & 2 & 0.77 & 0.385 & $\ldots .$. \\
\hline Within systems of mating... & 82 & 81.99 & 1.00 & \\
\hline
\end{tabular}

* $\mathrm{F}$ values at $5 \%$ and $1 \%$ points are 3.11 and 4.88 respectively.

TABLE 8

ANALYSIS OF VARIANCE OF THE DATA ON FERTILITY FOR FERTILE MATINGS ONLY IN 1940 USING WEIGHTED AVERAGES $(\bar{p})$

\begin{tabular}{|c|c|c|c|c|}
\hline Source of variation & $\begin{array}{l}\text { Degrees of } \\
\text { freedom }\end{array}$ & $\begin{array}{l}\text { Sums of } \\
\text { squares }\end{array}$ & $\begin{array}{c}\text { Mean } \\
\text { square }\end{array}$ & $\mathrm{F}^{*}$ \\
\hline 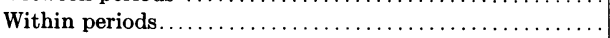 & 59 & 59.58 & 1.01 & \\
\hline Between origins of males... & 2 & 1.24 & 0.62 & $\ldots$. \\
\hline Between origins of females.............. & 2 & 32.02 & 16.01 & 15.85 \\
\hline 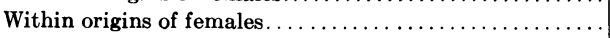 & 59 & 59.65 & 1.01 & \\
\hline Between systems of mating $\ldots \ldots \ldots \ldots \ldots \ldots \ldots \ldots \ldots \ldots$ & 2 & 0.02 & 0.01 & $\ldots$. \\
\hline
\end{tabular}

* $\mathrm{F}$ values at $5 \%$ and $1 \%$ points are 3.15 and 4.98 respectively.

The analysis of variance of fertility between origins of males (tables 7,8 , and 9) shows that the variations are significant only in 1941. These significant variations observed in 1941 are apparently entirely explained by males P183 and P184 (XB males) which showed a fertility lower by $14.6 \%$ and $12 \%$ respectively when compared to S193-S194 (SEOBs) and S195-S196 (OB ${ }^{2}$ ) as reported in table 10 .

The analysis of variance shows that the differences in fertility observed between origins of females are statistically significant in 1940 and in 1941, whether or not the completely infertile matings are taken into account. The origins of the females apparently account for a great part, if not the greatest 
part, of the differences observed in fertility. The most significant fact is undoubtedly the lower fertility exhibited in both years by the Leghorn females with an inbred origin ( $\mathrm{SE}$ and $\mathrm{OB}^{2}$ ) when compared with those having an outbred origin (OB and SEOB).

The variations in fertility between mating systems appeared to be of no significance and this was confirmed by an analysis of variance. Inbreeding,

TABLE 9

ANALYSIS OF VARIANCE OF THE DATA ON FERTILITY FOR ALL MATINGS IN 1941 USING WEIGHTED AVERAGES $(\bar{p})$

\begin{tabular}{|c|c|c|c|c|}
\hline Source of variation & $\begin{array}{l}\text { Degrees of } \\
\text { freedom }\end{array}$ & $\begin{array}{l}\text { Sums of } \\
\text { squares }\end{array}$ & $\begin{array}{c}\text { Mean } \\
\text { square }\end{array}$ & $\mathrm{F}^{*}$ \\
\hline Between periods. $\ldots \ldots \ldots \ldots \ldots \ldots \ldots \ldots \ldots \ldots \ldots \ldots \ldots \ldots \ldots \ldots$ & 2 & 3.47 & 1.74 & 1.91 \\
\hline Within periods $\ldots \ldots \ldots \ldots \ldots \ldots \ldots \ldots \ldots \ldots \ldots \ldots \ldots \ldots \ldots$ & 118 & 107.64 & 0.91 & \\
\hline Between origins of males. & 2 & 9.51 & 4.76 & 4.62 \\
\hline Within origins of males.............. & 118 & 121.72 & 1.03 & \\
\hline Between origins of females... & 2 & 7.57 & 3.78 & 3.94 \\
\hline Within origins of females..... & 118 & 113.53 & 0.96 & \\
\hline Between inbreeding and crossbreeding. & 1 & 0.02 & 0.02 & $\ldots$ \\
\hline Within inbreeding and crossbreeding $\ldots \ldots \ldots \ldots \ldots$ & 119 & 120.46 & 1.01 & \\
\hline Between levels of inbreeding. & 2 & 0.17 & 0.085 & $\ldots$ \\
\hline Within levels of inbreeding. . & 67 & 70.83 & 1.06 & \\
\hline
\end{tabular}

* $\mathrm{F}$ values at $5 \%$ and $1 \%$ points are 3.08 and 4.80 respectively.

TABLE 10

FERTILITY OBTAINED WITH THE FEMALES OF THE TWO BREEDS WHEN MATED TO THE MALES OF THE THREE ORIGINS (1941)

\begin{tabular}{|c|c|c|c|}
\hline Females & $\begin{array}{l}\text { SEOBs } \\
\text { males }\end{array}$ & $\begin{array}{c}\text { OB2 }^{2} \\
\text { males }\end{array}$ & $\begin{array}{c}\mathrm{XB} \\
\text { males }\end{array}$ \\
\hline $\begin{array}{l}\text { White Leghorns } \\
\qquad\left(\mathrm{OB}^{2} \text {, SEOBs and SEOBl }\right) \ldots \ldots \ldots \ldots \ldots\end{array}$ & .9189 & .8824 & .7850 \\
\hline $\begin{array}{l}\text { Crossbreds } \\
\quad(\mathrm{XB}) \ldots \ldots \ldots \ldots \ldots \ldots \ldots \ldots \ldots \ldots \ldots \ldots\end{array}$ & .9557 & .9732 & .8026 \\
\hline Average & .9332 & .9077 & .7871 \\
\hline
\end{tabular}

outcrossing, crossbreeding, and inbreeding to varying levels apparently did not affect fertility in a direct way, or, in other words, the fertilization of an egg was neither impaired nor enhanced by the presence of sperm from a related or an unrelated male.

The data on fertility were also analyzed statistically by another method than that of Hendricks (1935) as the weighted averages $(\bar{p})$ could not be used in the analysis of covariance of fertility and hatchability reported on in another part of this study (page 571). In the second method of analysis, the individual percentages of fertility were converted to angles and used in a standard analysis of variance. 
The results of this second analysis, given in table 11, are in complete agreement with those obtained in the first. Significant differences in fertility between periods were observed in 1940 but not in 1941. Significant differences in fertility were observed between origins of males only in 1941 and between origins of females in both years, while the differences between systems of mating were not significant.

\section{TABLE 11}

ANALYSIS OF VARIANCE OF DATA ON FERTILITY IN 1940 AND 1941 FOR FERTILE MATINGS ONLY, USING INDIVIDUAL PERCENTAGES OF FERTILITY CONVERTED TO ANGLES

\begin{tabular}{|c|c|c|c|c|c|c|}
\hline \multirow{2}{*}{ Source of variation } & \multicolumn{3}{|c|}{1940} & \multicolumn{3}{|c|}{1941} \\
\hline & $\begin{array}{l}\text { Degrees of } \\
\text { freedom }\end{array}$ & $\begin{array}{c}\text { Mean } \\
\text { square }\end{array}$ & $\mathrm{F}$ & $\begin{array}{l}\text { Degrees of } \\
\text { freedom }\end{array}$ & $\begin{array}{c}\text { Mean } \\
\text { square }\end{array}$ & $\mathbf{F}$ \\
\hline Total. . & 61 & 659.26 & & 107 & 222.01 & \\
\hline Between periods............ & 2 & 2659.18 & $4.50^{*}$ & 2 & 17.48 & $\ldots$ \\
\hline Within periods. . . . . $\ldots \ldots \ldots$ & 59 & 591.47 & & 105 & 225.91 & \\
\hline Between origins of males. & 2 & 321.54 & $\ldots$ & 2 & 1256.07 & $6.21 \dagger$ \\
\hline Within origins of males... & 59 & 670.71 & & 105 & 202.31 & \\
\hline Between origins of females.... & 2 & 7286.20 & $16.76 \dagger$ & 2 & 1097.70 & $5.35 \dagger$ \\
\hline Within origins of females..... & 59 & 434.62 & & 105 & 205.33 & \\
\hline Between systems of mating... & 2 & 42.46 & $\ldots$ & 1 & 6.01 & $\ldots$ \\
\hline Within systems of mating..... & 59 & 680.17 & & 106 & 224.05 & \\
\hline
\end{tabular}

* Significant at the $5 \%$ level.

t Significant at the $1 \%$ level.

\section{Relation Between Intensity of Egg Production and Fertility}

In the study of the incidence of infertile matings (table 3), infertility was higher in hens laying at a rate less rapid than the average, but the differences were not statistically significant. It seemed of interest to study the relationship between rate of production and fertility in all the matings studied.

Table 12 presents a summary of the data on the relation between rate of production and percentage of fertility for each individual mating in 1940 and 1941. The fertile matings of 1940 were analyzed separately. The same table also gives the results of the heterogeneity tests of the distributions. These heterogeneity tests of the distribution of the matings according to rate of production and fertility reveal that in 1940 there was no significant relation between fertility and rate of production whether all or only the fertile matings were taken into consideration. In 1941, however, there was a significant relation between rate of production and fertility.

The lack of significant relation between rate of production and fertility in 1940 may have been the result of conditions associated with the various origins of the females. As was shown previously (table 3), the SE females showed a higher incidence of infertile matings than either the OB or the CB females but this higher incidence of infertile matings was not explained by a 
TABLE 12

DISTRIBUTION OF MATINGS ACCORDING TO RATE OF PRODUCTION AND FERTILITY

\begin{tabular}{|c|c|c|c|c|}
\hline \multirow{2}{*}{ Rate of production } & \multicolumn{2}{|c|}{$\begin{array}{l}\text { Percentage of fertility } \\
1940 \text { (all matings) }\end{array}$} & \multirow{2}{*}{$\begin{array}{l}\text { Number of } \\
\text { matings }\end{array}$} & \multirow{2}{*}{$\begin{array}{l}\text { Average } \\
\text { fertility }\end{array}$} \\
\hline & $\begin{array}{l}\text { Less than the } \\
\text { median or } 53 \%\end{array}$ & $\begin{array}{l}\text { More than the } \\
\text { median or } 53 \%\end{array}$ & & \\
\hline Less than the median or 18 eggs.............. & 24 & 23 & 47 & .4530 \\
\hline More than the median or $18 \mathrm{eggs} . \ldots \ldots \ldots \ldots \ldots$ & 14 & 24 & 38 & .6239 \\
\hline Total. . & 38 & 47 & 85 & .5297 \\
\hline \multicolumn{5}{|c|}{$\chi^{2}=1.19 \quad \mathrm{P}=.20-.30$} \\
\hline \multirow{2}{*}{ Rate of production } & \multicolumn{2}{|c|}{$\begin{array}{l}\text { Percentage of fertility } \\
1940 \text { (fertile matings) }\end{array}$} & \multirow{2}{*}{$\begin{array}{l}\text { Number of } \\
\text { matings }\end{array}$} & \multirow{2}{*}{$\begin{array}{l}\text { Average } \\
\text { fertility }\end{array}$} \\
\hline & $\begin{array}{l}\text { Less than the } \\
\text { median or } 90 \%\end{array}$ & $\begin{array}{l}\text { More than the } \\
\text { median or } 90 \%\end{array}$ & & \\
\hline Less than the median or 18 eggs.... & 20 & 11 & 31 & .6868 \\
\hline More than the median or 18 eggs.... & 13 & 18 & 31 & .7898 \\
\hline \multirow[t]{2}{*}{ Total. . } & 33 & 29 & 62 & .7263 \\
\hline & \multicolumn{3}{|c|}{$\chi^{2}=2.33$} & \\
\hline \multirow{2}{*}{ Rate of production } & \multicolumn{2}{|c|}{$\begin{array}{l}\text { Percentage of fertility } \\
1941 \text { (all matings) }\end{array}$} & \multirow{2}{*}{$\begin{array}{l}\text { Number of } \\
\text { matings }\end{array}$} & \multirow{2}{*}{$\begin{array}{l}\text { Average } \\
\text { fertility }\end{array}$} \\
\hline & $\begin{array}{l}\text { Less than the } \\
\text { mean or } 86 \%\end{array}$ & $\begin{array}{l}\text { More than the } \\
\text { mean or } 86 \%\end{array}$ & & \\
\hline Less than the median or 16 eggs.... & 22 & 36 & 58 & .8319 \\
\hline More than the median or 16 eggs... & 8 & 55 & 63 & .9232 \\
\hline \multirow[t]{2}{*}{ Total.... } & 30 & 91 & 121 & .8795 \\
\hline & & $\chi^{2}=9.01$ & $=.01-.001$ & \\
\hline
\end{tabular}

decreased rate of production. It seems reasonable to venture the hypothesis that factors other than decreased rate of production are responsible for the decreased fertility observed in 1940.

The relation between rate of production and fertility was also studied within origins of females in 1940 and it remained without significance.

\section{Relation Between Coefficients of Inbreeding of Dams and Their Fertility}

The fact that the SE females, with an inbred origin, were significantly less fertile than the OB females, led to the study of the relation between the coefficients of inbreeding of the individual SE females and the fertility of their eggs regardless of the male they were mated with. The range in coeff- 
cients of inbreeding of the $14 \mathrm{SE}$ females used in 1940 was from zero to .46 while the fertility varied between zero and $96 \%$.

The results of the analysis of covariance of coefficients of inbreeding and percentages of fertility converted to angles gave a negative coefficient of correlation of -.540 which is significant at the $5 \%$ level of significance.

Another method of testing the available data on inbreeding and fertility for association was used: a test of the heterogeneity of the distribution of infertile and fertile eggs according to coefficients of inbreeding. The results are presented in table 13. This test of heterogeneity reveals that the level of

TABLE 13

DISTRIBUTION OF INFERTILE AND FERTILE EGGS ACCORDING TO THE COEFFICIENT OF INBREEDING OF THE BIRDS THAT LAID THEM. DATA FROM THE SE FEMALES IN 1940

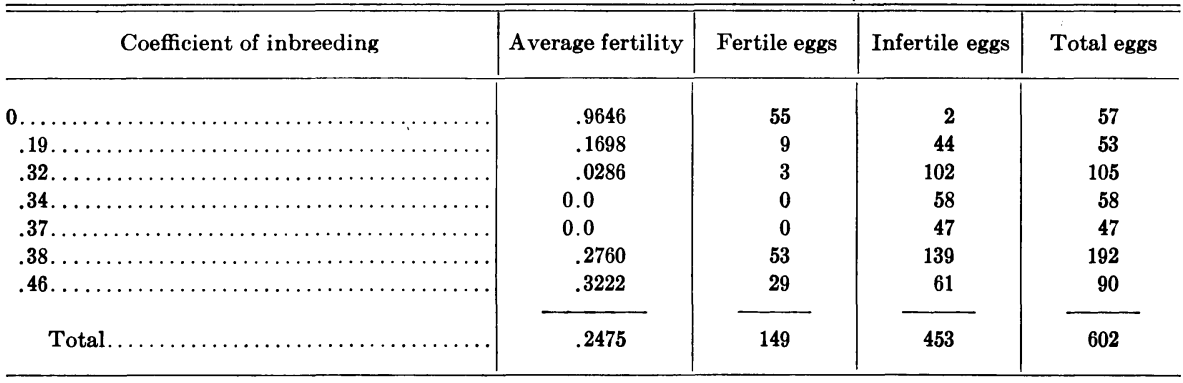

$\chi^{2}=121.49, \quad \mathrm{P}<.001$

fertility is significantly related to the coefficient of inbreeding of the various dams. Better fertility was observed in the eggs from dams with a low (zero) and a high (.38 or more) coefficient of inbreeding than in the eggs from dams with a coefficient of inbreeding varying between .1875 and .37 . The results of the analysis of covariance are thus confirmed by the test of the heterogeneity of the distribution of infertile and fertile eggs according to coefficients of inbreeding. The data presented in table 13 reveal a non-linear relationship between coefficient of inbreeding and fertility. More reliance is put on the results presented in table 13 than on the correlation coefficient previously reported in view of the fact that normality is not a prerequisite for a test of heterogeneity whereas it is for a covariance analysis.

The test of heterogeneity reported in table 13 might be criticized for lack of correction for different levels of production, but it was demonstrated previously, table 12, that there was no significant relation between rate of egg production and fertility in the SE females in 1940.

The study of the relation between coefficients of inbreeding and fertility could not be made in the females used in 1941 because of the small range of variation in the inbreeding coefficients in any one line. 


\section{DISCUSSION}

The results obtained in this part of the study of the relative effects of inbreeding and outbreeding are that inbreeding to varying degrees, outcrossing, and crossbreeding do not affect fertility directly, but that they do so indirectly. In this study the fertility of hens was apparently neither impaired nor enhanced when they were mated to either related or unrelated males. The most significant fact observed is that the SE and CB females, both with an inbred origin, showed a higher incidence of infertile matings and also had lower fertility in fertile matings than the OB females with an outbred origin. This finding is contrary to the prevalent opinion that fertility in the domestic fowl is not hereditary. The fertility of matings appears to be a property of the parents and not of the prospective zygotes resulting from the mating. This may be the reason for the lack of agreement in conclusions of the many investigations on the heredity of fertility in the domestic fowl.

The indirect effects of inbreeding on fertility are very clearly demonstrated in the results obtained in this study. The inbred Leghorn females, in both years, were significantly less fertile than the outbred Leghorn females. The reasons for this impaired fertility of inbred females remain undetermined but the analysis made of the results obtained provides a number of hypotheses.

It is generally admitted that inbreeding results in decreased vigor of the progeny and it is not illogical to assume that a decrease in sexual receptivity accompanies such a decrease in vigor. The infertility and lowered fertility of inbred females would thus be explained by the absence of or less frequent mating. It is interesting to note that the inbred Leghorn males, in both years, did not show any significant difference in their sexual activity when compared to outbred males of the same breed. This is perhaps explained by the small number of males used in the study and the possible selection of vigorous individuals.

A significant relation was observed between origins of males and origins of females and incidence of infertile matings in 1940. In the same year, 1940, there was no significant relation between fertility and rate of production. whether all the matings or only the fertile matings were considered. In 1941, the relation between rate of production and fertility was significant. Lamoreux (1940) has reported that the relation between rate of production and fertility is explained by the greater sexual receptivity of the females laying at a high rate.

As hypotheses to explain the high incidence of infertility and the reduced fertility of the inbred females, particularly the SE females, the following are suggested : First, the inbred females because of their reduced vigor show a decreased sexual receptivity. This first hypothesis is weakened by the lack of relation observed between rate of production and fertility in the inbred females. A second hypothesis is that the eggs of the inbred females are fertilized but the zygotes die so early that it is impossible to determine whether or not the eggs were fertile. This hypothesis cannot be definitely rejected until better means of detecting early embryonic mortality are available. A third hypothesis is that the inbred females exhibit a normal relation between rate of 
production and sexual receptivity but to no avail because their eggs are of such a constitution that they cannot be fertilized. A fourth hypothesis is that certain conditions in the oviduct of the inbred females do not permit the survival of the sperm or its ascension to the infundibulum of the oviduct. The third and fourth hypotheses are supported by the fact that attempts to obtain fertile eggs from certain of the inbred SE females through artificial insemination proved futile and the females remained infertile. Another fact is that the males which were in turn mated to the inbred SE and the CB females gave very good fertility with the outbred OB females so that viability of sperm was not at fault.

Substantial evidence has been presented in this study to show that genetic factors definitely influenced fertility as demonstrated by the low level of fertility in many inbred females. The actual reasons for this impaired fertility have not been determined but future investigations may establish that certain of the hypotheses suggested above apply.

In addition to the findings just discussed, the results of this study on fertility showed a striking difference in fertility between the two years which is not explained by the infertile matings observed in the first year. There was also evidence of a seasonal decline in fertility as the incubation season progressed, but the differences between periods were statistically significant only in the first year. The males used in the two years, except for the XB set in 1941, showed no significant difference in their sexual activity as manifested by the fertility of the eggs of their common mates. The SE and CB males gave a higher incidence of infertile matings in 1940 but this was not statistically significant. The females were apparently mainly responsible for the significant variations observed in infertility and fertility.

\section{SUMMARY}

The results of this study on fertility based on two years' observations of triallel matings of hens having an inbred, outbred, and inbred-crossbred origin, demonstrate that inbreeding, in itself or to varying coefficients, outcrossing, and crossbreeding, do not influence fertility directly. However, the breeding system responsible for the production of a population of females has an effect on their fertility. Thus, hens of an inbred origin are definitely less fertile than those of an outbred origin, irrespective of the kind of male to which they are mated. Birds laying at a higher rate than the average produced a higher percentage of fertile eggs in one of the two years. 


\section{The Relative Effects of Inbreeding and Outbreeding on Reproduction in the Domestic Fowl}

\section{PAUL E. BERNIER, LEWIS W. TAYLOR, and C. A. GUNNS}

\section{HATCHABILITY}

NumERous FACTORs have been found to affect the hatchability of fertile eggs in the domestic fowl. These factors are both environmental and hereditary and they have been the subject of many investigations. Fortunately the vast amount of literature has been very adequately reviewed by Jull (1940) and especially by Landauer (1941) so that it is not necessary to review the subject here as a whole except for the phases bearing directly or indirectly on the factors studied in this investigation.

The influence of genetic factors on hatchability has been demonstrated in a number of ways. Waters (1944) has reported significantly greater variation in hatchability between dams than within dams. Pearl and Surface (1909), Hays and Sanborn (1924), Jull (1931), and Landauer (1937, 1941) have all reported significant coefficients of correlation between the hatchability of dams and that of their female progeny. Hays (1926) and Waters (1944) have both used polyallel crossing, the mating of the same females to different males, to demonstrate the influence of genetic factors on hatchability.

Another way of demonstrating the influence of genetic factors on hatchability is its behavior following inbreeding and outbreeding. Dryden (1916), Cole and Halpin (1916, 1922), Dunn (1923, 1928), Goodale (1927), Warren (1927, 1934), Jull (1929a, b), Dumon (1931), Dunkerley (1931), the Northern Subcommittee (1934), Byerly, Knox and Jull (1934), Vecchi (1936), Waters (1932, 1945), Waters and Lambert (1935, 1936a, b, c) and Knox (1946) have all reported that hatchability decreases as inbreeding increases. By rigid selection, however, Waters and Lambert $(1935,1936 a, b, c)$ and Knox (1946) successfully established inbred lines showing relatively high hatchability.

Finally, a number of lethal and semi-lethal genes resulting in decreased hatchability have been isolated in the course of investigations conducted with the domestic fowl. Jull (1940) has pointed out that these lethals cannot be responsible for any considerable portion of the embryonic mortality commonly observed in most flocks, but they are nevertheless of importance in inbreeding investigations as revealed by Waters (1945). A check-list of lethal and semilethal factors in the domestic fowl has been published by Lerner (1944).

\section{Materials and Methods}

The eggs collected three days each week, Tuesday, Friday, and Saturday, and set in the incubator the following Monday constituted the material used to measure hatchability. Each individual egg was identified as to parents 
and hour and date of laying. The eggs were regularly candled on the seventh and fourteenth days of incubation; all eggs removed at such candlings and those remaining after the chicks were hatched were broken to determine whether they had been fertile, the stage at which the embryos had died and the determinable causes of death.

The data obtained were analyzed in the same manner as the data on fertility. Hatchability was expressed as the percentage of fertile eggs that produced chicks.

\section{Analysis of Observations}

In the course of the two years during which observations were made on hatchability, a total of 72 females used in 169 matings produced a total of 937 fertile eggs from which 701 chicks hatched. The data available in each year and for the two years together are summarized in table 14.

TABLE 14

DATA ON HATCHABILITY FOR 1940 AND 1941

\begin{tabular}{c|c|c|c|c|c|c|c}
\hline \hline \multirow{2}{*}{ Year } & \multicolumn{2}{|c|}{ Number of: } & \multicolumn{2}{|c|}{ Number of eggs } & $\begin{array}{c}\text { Number } \\
\text { of fertile } \\
\text { eggs }\end{array}$ & $\begin{array}{c}\text { Hatch- } \\
\text { ability }\end{array}$ & $\begin{array}{c}\text { Weighted } \\
\text { average }(\bar{p}) \text { SE }\end{array}$ \\
\cline { 2 - 7 } & Birds & Matings & Total & Per mating & & \\
\hline $1940 \ldots \ldots \ldots \ldots \ldots$ & 29 & 60 & 381 & 6.35 & 282 & .7006 & $.7582 \pm .0369$ \\
$1941 \ldots \ldots \ldots \ldots \ldots$ & 43 & 109 & 556 & 5.10 & 419 & .7536 & $.7803 \pm .0133$ \\
Both years.... & 72 & 169 & 937 & 5.54 & 701 & .7481 & $.7801 \pm .0218$ \\
\hline
\end{tabular}

The difference in hatchability between the two years is not very large but the data gathered in each year are nevertheless analyzed separately since different birds were used.

\section{Analysis of Variation in Hatchability}

The data available for each year on hatchability, arranged according to periods, origins of males, origins of females and systems of mating, are presented in table 15.

Periods, origins of males, origins of females, and systems of mating appear to have influenced hatchability to varying degrees. The data, weighted within each classification, were submitted to an analysis of variance to determine the significance of the variations observed. The results of the analysis of variance for both the 1940 and 1941 data are presented in table 16.

The variations in hatchability did not show the same periodic trends in 1940 and 1941 (table 15). Hatchability was at a maximum during the first period in 1940 and in the second period in 1941, but as stated previously in the study of fertility, the periods did not coincide in the two years. The second period in 1941 more nearly corresponded to the first in 1940 so that when the data for both years were considered together the trend was an increase in February and March as compared to January and a decrease in April and May as compared to March. The analysis of variance of the data on hatchability revealed that the variations between periods were not significant in 1940, but were so in 1941. No explanation is offered for these periodic variations in hatchability. 
TABLE 15

DATA ON HATCHABILITY IN 1940 AND 1941 ARRANGED ACCORDING TO PERIODS, ORIGINS OF MALES, ORIGINS OF FEMALES AND SYSTEMS OF MATING

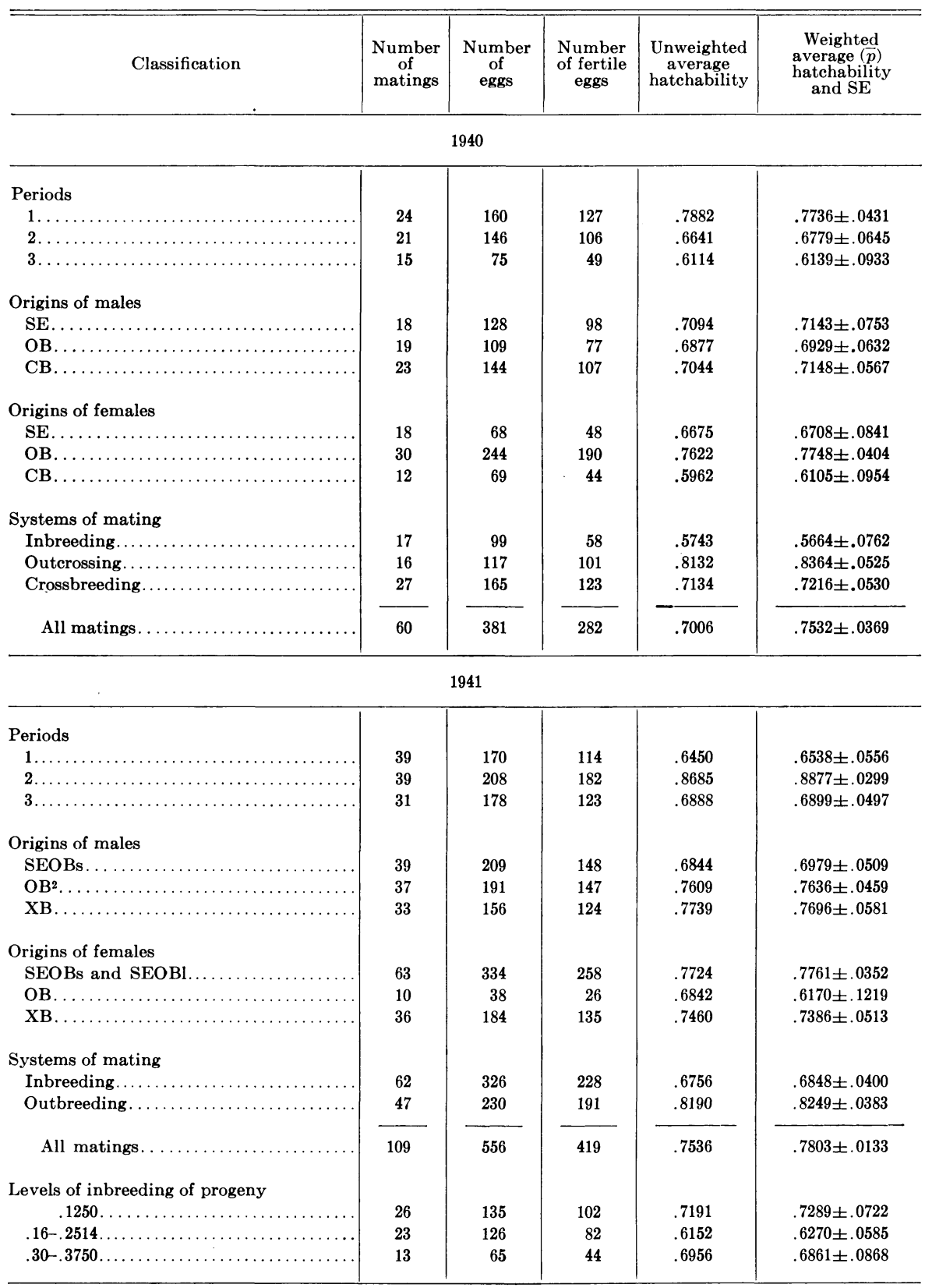


The sets of males used in 1940 and in 1941 (table 15) did not apparently affect hatchability to any marked degree and this is confirmed by the analysis of variance. No set of males was definitely inferior or superior in hatchability, in either of the two years, when mated in turn to all the females.

The data arranged according to origins of females (table 15) show that, in the White Leghorns, in 1940 the inbred SE females and in 1941 the inbred

TABLE 16

ANALYSIS OF VARIANCE OF THE DATA ON HATCHABILITY FOR 1940 AND 1941 USING WEIGHTED AVERAGES $(\bar{p})$

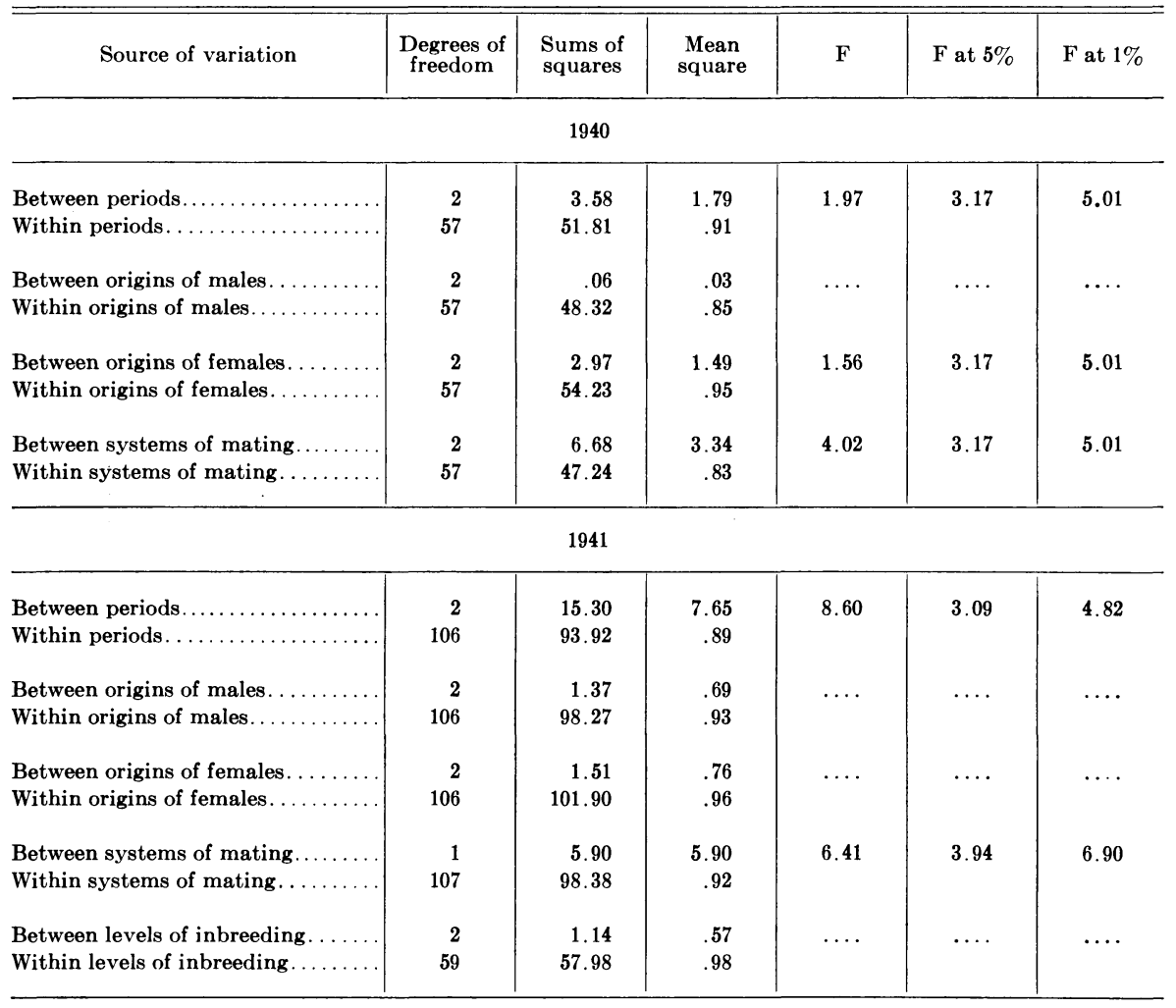

$\mathrm{OB}^{2}$ females gave inferior hatchability when compared to the outbred $\mathrm{OB}$ and SEOB females respectively. The analysis of variance (table 16), however, shows that the variations observed between origins of females are not significant in either 1940 or 1941 . Thus no origin of females was definitely inferior or superior in hatchability, in either of the two years, when mated in turn to the sets of males of the different origins.

Inbreeding gave the lowest hatchability results in both 1940 and 1941 (table 15 ) and the analysis of variance (table 16) revealed that the variations between systems of mating were statistically significant for each year. In 1941, there was no significant variation in hatchability between the various levels 
of inbreeding. Maximum hatchability was obtained under outerossing in 1940 and under outbreeding in 1941.

The data on hatchability were also analyzed by another method than that of weighted averages $(\bar{p})$ as was previously done for the data on fertility (table 11). This second method was used for the analysis of covariance of fertility and hatchability using percentages converted to angles, since the weighted averages could not be utilized in the analysis of covariance. The results of this second analysis of variance of the data on hatchability for both years are presented in table 17.

The results of the two methods for analysis of variance are in complete agreement except for the discrepancy in significance of the analyses between systems of mating in 1940 . The method of weighted averages $(\bar{p}$, table 16$)$ showed the variance between systems of mating in 1940 as significantly greater than the variance within systems of mating while the method of percentages converted to angles (table 17) showed the same variance ratio not to be significant.

It was also possible to extend this second method for the analysis of variance within periods, within origins of females within periods, within systems of mating within origins of females within periods, and finally within inbreeding within origins of females within periods, as shown in the lower part of table 17. The extended analysis of variance within each origin of females within periods is also given in the same table. The results indicate significant variations between origins of females within periods and between systems of mating within origins of females within periods, but in 1941 only. The analysis of the variations in hatchability within each origin has shown that only the $\mathrm{OB}$ females in 1940 exhibited significant variations in hatchability between systems of mating within periods.

The extended analysis of variance has thus revealed a few facts which would have remained unknown otherwise. It is of interest to note that the discrepancy between the two methods of analysis for 1940 seems to be explained by the fact that only the females of OB origin showed significant variations in hatchability between systems of mating; the inbreeding of these females resulted in lower hatchability. In 1941, the three origins of females exhibited lower hatchability when inbred but the analysis showed that the variance ratios never reached the level of significance. When the three origins are pooled the variations in hatchability between systems of mating are significant ( $\mathrm{F}$ value of 2.12), inbreeding showing significantly lower hatchability than outbreeding.

\section{Relation Between Rate of Egg Production and Hatchability}

The data on egg production and on hatchability were analyzed for a possible relationship. Table 18 represents a summary of the available data on the hatchability of fertile eggs laid by hens laying less and more than the median number of eggs during each period.

There is an apparent relationship between rate of production and hatchability since in both years the hens that laid more intensively also produced fertile eggs that hatched better than those laid by hens laying less intensively. 
TABLE 17

ANALYSIS OF VARIANCE OF DATA ON HATCHABILITY IN 1940 AND 1941 USING INDIVIDUAL PERCENTAGES CONVERTED TO ANGLES

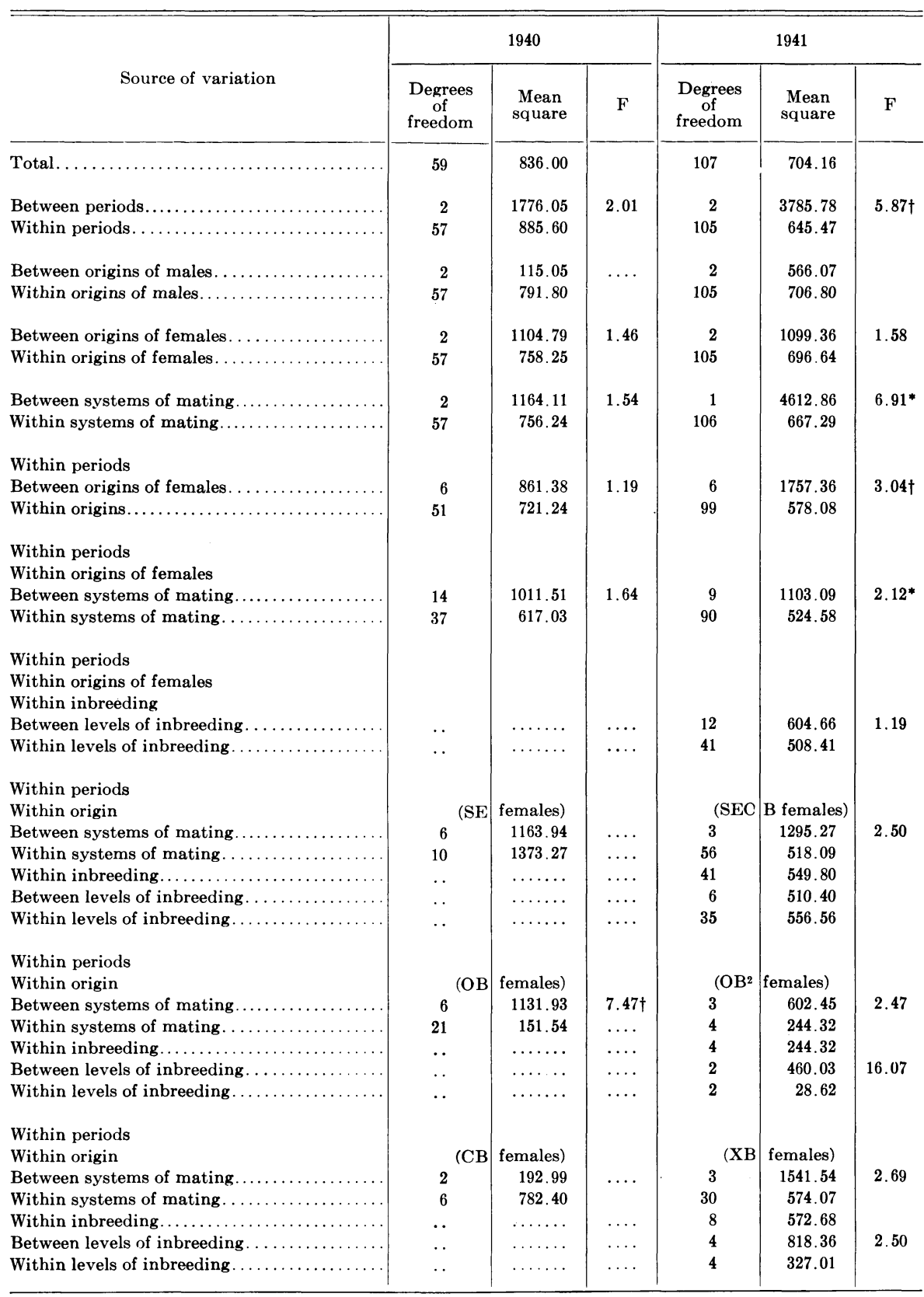

* Significant at the $5 \%$ level.

+ Significant at the $1 \%$ level. 
The tests of heterogeneity of the distribution of matings according to rate of production and hatchability have revealed, however, that the relation between rate of production and hatchability is significant only for 1941. It is interesting to recall that in 1940 there was also no relation between rate of production and fertility.

TABLE 18

RELATION BETWEEN RATE OF EGG PRODUCTION AND HATCHABILITY TOGETHER WITH TESTS OF HETEROGENEITY OF THE FREQUENCIES

\begin{tabular}{|c|c|c|c|c|}
\hline \multirow{2}{*}{ Rate of production } & \multicolumn{2}{|c|}{$\begin{array}{c}\text { Percentage of hatchability } \\
1940\end{array}$} & \multirow{2}{*}{$\begin{array}{l}\text { Number of } \\
\text { matings }\end{array}$} & \multirow{2}{*}{$\begin{array}{c}\text { Average } \\
\text { hatchability }\end{array}$} \\
\hline & $\begin{array}{l}\text { Less than the } \\
\text { median or } 70 \%\end{array}$ & $\begin{array}{l}\text { More than the } \\
\text { median or } 70 \%\end{array}$ & & \\
\hline Less than the median or 18 eggs.... & 14 & 15 & 29 & .6579 \\
\hline More than the median or 18 eggs. . & 10 & 21 & 31 & .7419 \\
\hline \multirow[t]{2}{*}{ All matings. } & 24 & 36 & 60 & .7006 \\
\hline & \multicolumn{2}{|r|}{$\chi^{2}=1.00$} & $\mathrm{P}=.317$ & \\
\hline \multirow{2}{*}{ Rate of production } & \multicolumn{2}{|c|}{$\begin{array}{l}\text { Percentage of hatchability } \\
1941\end{array}$} & \multirow{2}{*}{$\begin{array}{c}\text { Number of } \\
\text { matings }\end{array}$} & \multirow{2}{*}{$\begin{array}{c}\text { Average } \\
\text { hatchability }\end{array}$} \\
\hline & $\begin{array}{l}\text { Less than the } \\
\text { median or } 78 \%\end{array}$ & $\begin{array}{l}\text { More than the } \\
\text { median or } 78 \%\end{array}$ & & \\
\hline Less than the median or 17 eggs. & 29 & 30 & 59 & .6502 \\
\hline More than the median or 17 eggs. & 14 & 36 & 50 & .8410 \\
\hline \multirow[t]{2}{*}{ All matings.................. } & 43 & 66 & 109 & .7536 \\
\hline & & $\chi^{2}=4.21$ & $\mathrm{P}=.04$ & \\
\hline
\end{tabular}

\section{Relation Between Clutch Position of Fertile Eggs and Their Hatchability}

The data accumulated in this study permitted an analysis of the relation between clutch position of fertile eggs and their hatchability. Table 19 presents the results of the analysis.

Eggs occupying a clutch position intermediate between the first and the last hatched significantly better than the eggs occupying the first and the last clutch positions. The distribution of hatched and unhatched fertile eggs in the first and last clutch positions was tested for heterogeneity in clutches of varying sizes. The results are presented in table 20 .

The hatchability of first and last eggs in a clutch is apparently not influenced by the size of the clutch to which they belong. Last eggs in a clutch show a tendency to hatch less well in shorter than in longer clutches, but the test of heterogeneity has given a $\chi^{2}$ value slightly over the $5 \%$ level of significance. The hatchability of first and last eggs in a clutch is apparently independent of the rate of egg production. 
TABLE 19

DISTRIBUTION OF HATCHED AND UNHATCHED FERTILE EGGS ACCORDING TO CLUTCH POSITION FOR 1940 AND 1941 DATA

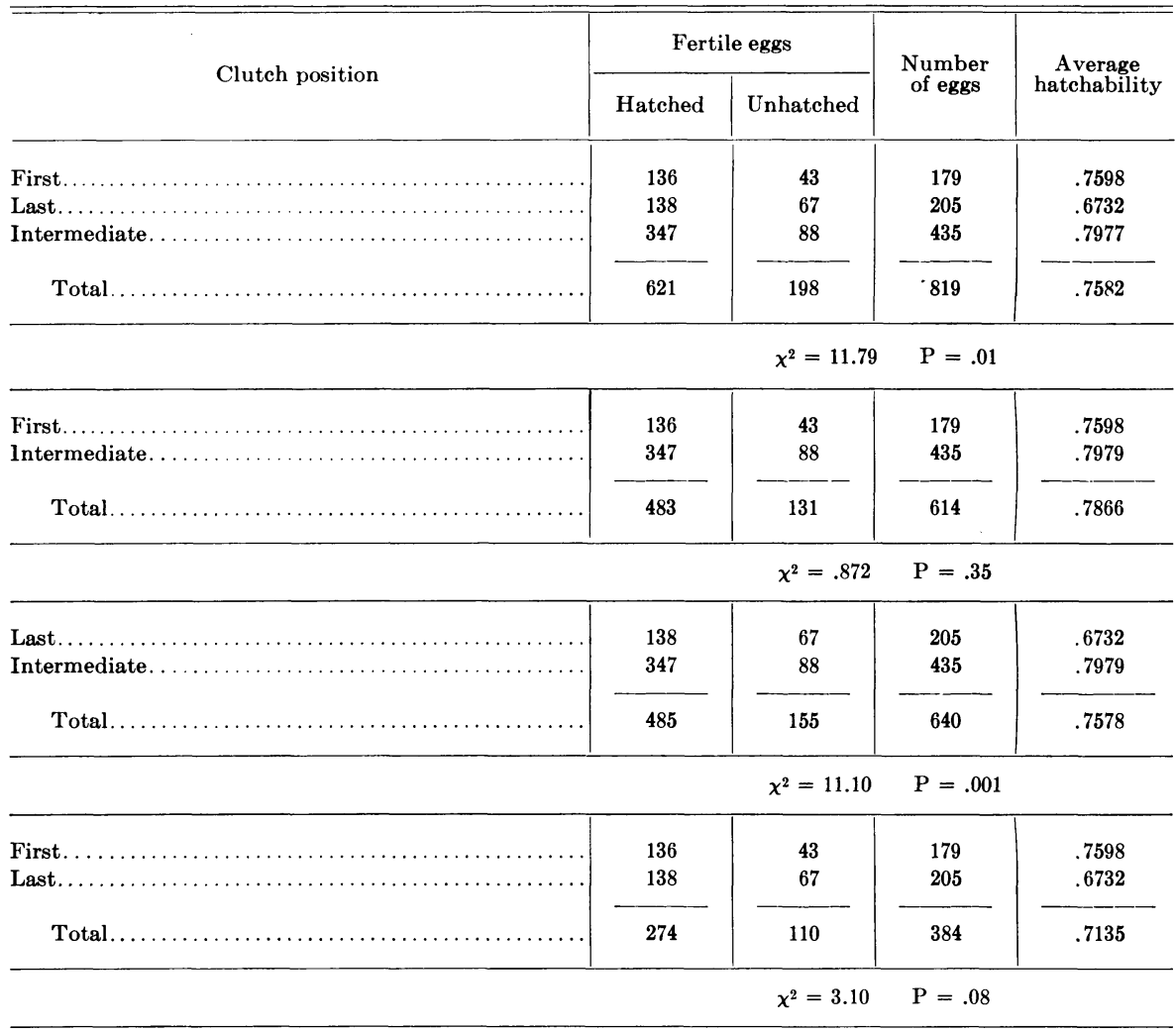

TABLE 20

DISTRIBUTION OF HATCHED AND UNHATCHED EGGS IN FIRST AND LAST CLUTCH POSITIONS ACCORDING TO SIZE OF CLUTCH

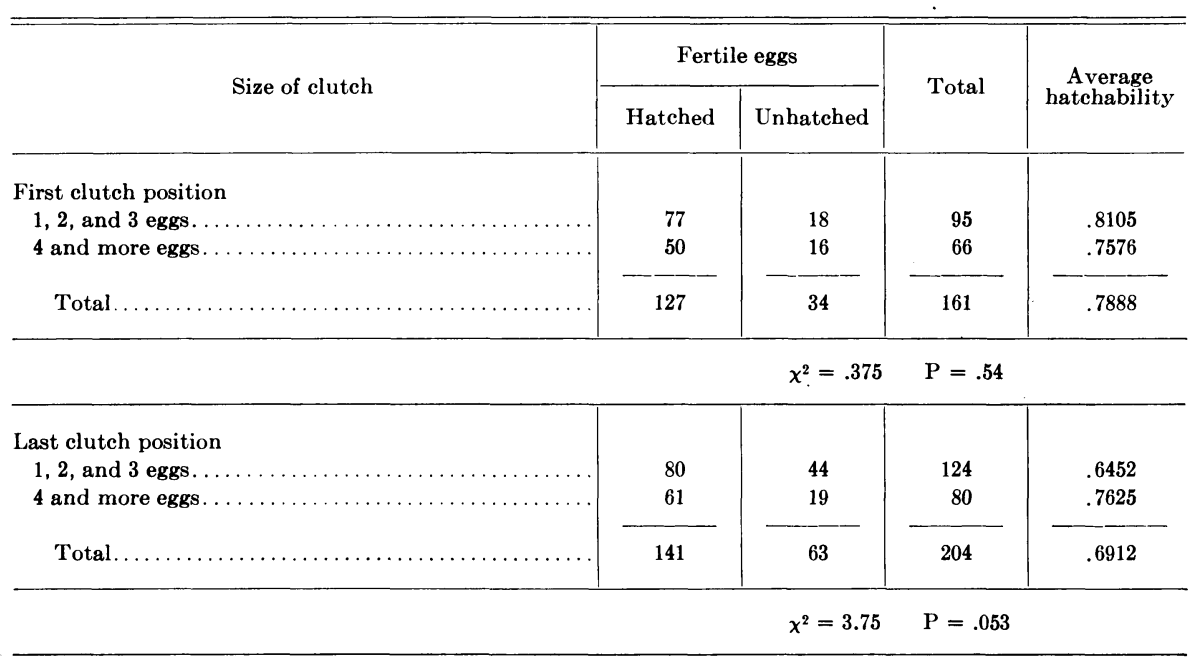




\section{Relation Between Hour of Day Fertile Eggs Were Laid and Hatchability}

The fertile eggs available in 1940 and 1941 were classified according to the hour of the day they were laid and according to whether they hatched or not. Table 21 presents a summary of the analysis for fertile eggs in all clutch positions and within first and subsequent clutch positions.

TABLE 21

DISTRIBUTION OF FERTILE EGGS ACCORDING TO HOUR OF LAY AND HATCHABILITY

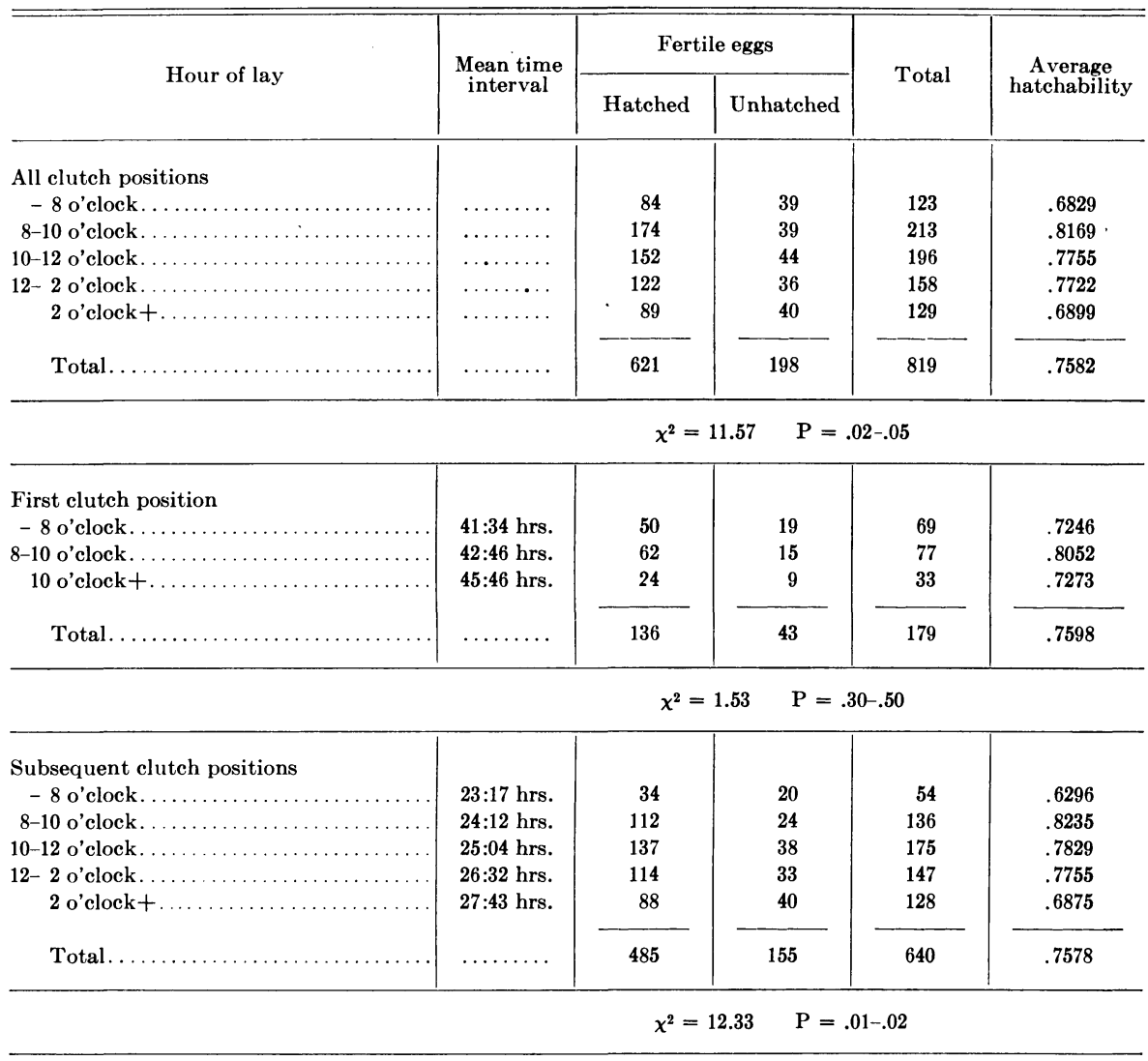

Fertile eggs laid before 8 o'clock in the morning did not hatch as well as eggs laid at other hours in the forenoon while eggs laid after 2 o'clock in the afternoon did not hatch as well as those laid between noon and 2 o'clock. Eggs laid between 9 o'clock in the morning and 2 o'clock in the afternoon consequently hatched better than those laid before or after. The test of heterogeneity of the frequencies of hatched and unhatched eggs according to hour 
of lay revealed that the differences are significant for eggs in all clutch positions and for eggs in clutch positions subsequent to the first. Eggs occupying first clutch position did not hatch as well when laid before 8 o'clock in the morning or after 10 o'clock in the morning but the differences were not statistically significant.

In table 21, along with the hour of the day the eggs were laid, time interval between the egg concerned and the preceding one is also reported. The later in the day the egg was laid the longer the average time interval whether the egg occupied first clutch position or a subsequent one.

TABLE 22

RELATION BETWEEN TIME INTERVAL BETWEEN EGGS AND HATCHABILITY

\begin{tabular}{|c|c|c|c|c|c|}
\hline \multirow{2}{*}{ Clutch position } & \multirow{2}{*}{$\begin{array}{c}\text { Time } \\
\text { interval }\end{array}$} & \multicolumn{2}{|c|}{ Fertile eggs } & \multirow{2}{*}{ Total } & \multirow{2}{*}{$\begin{array}{c}\text { Average } \\
\text { hatchability }\end{array}$} \\
\hline & & Hatched & Unhatched & & \\
\hline First................ & $\begin{array}{l}40-41 \text { hrs. } \\
42-43 \mathrm{hrs} \text {. } \\
44-48 \mathrm{hrs} \text {. }\end{array}$ & $\begin{array}{l}45 \\
56 \\
35\end{array}$ & $\begin{array}{l}15 \\
11 \\
17\end{array}$ & $\begin{array}{l}60 \\
67 \\
52\end{array}$ & $\begin{array}{l}.7500 \\
.8358 \\
.6731\end{array}$ \\
\hline \multirow[t]{2}{*}{ Total. } & $\ldots \ldots \ldots$ & 136 & 43 & 179 & .7598 \\
\hline & \multicolumn{4}{|c|}{$\chi^{2}=4.28$} & \\
\hline Subsequent to first........ & $\begin{array}{l}20-22 \mathrm{hrs} . \\
23-24 \mathrm{hrs} . \\
25-26 \mathrm{hrs} . \\
27-28 \mathrm{hrs} . \\
29-30 \mathrm{hrs} \text {. }\end{array}$ & $\begin{array}{r}27 \\
145 \\
157 \\
66 \\
6\end{array}$ & $\begin{array}{r}9 \\
40 \\
43 \\
24 \\
9\end{array}$ & $\begin{array}{r}36 \\
185 \\
200 \\
90 \\
15\end{array}$ & $\begin{array}{l}.7500 \\
.7838 \\
.7850 \\
.7333 \\
.4000\end{array}$ \\
\hline \multirow[t]{2}{*}{ Total. . } & $\ldots \ldots \ldots$ & 401 & 125 & 526 & .7624 \\
\hline & \multicolumn{4}{|c|}{$\chi^{2}=12.38$} & \\
\hline
\end{tabular}

\section{Relation Between Time Interval Between Eggs and Hatchability}

The data gathered in 1940 and 1941 permitted an analysis of the relation between the length of time interval and hatchability. The results of this analysis are presented in table 22 .

The eggs following the shortest and the longest time intervals did not hatch as well as those with a medium time interval, whether they occupied the first clutch position or one subsequent to the first. The tests of heterogeneity of the frequencies of hatched and unhatched eggs reveal that the differences are significant only in eggs occupying a clutch position subsequent to the first.

\section{DISCUSSION}

The most significant observation made in this study is perhaps the fact that only the females with an outbred origin, the OB females in 1940, have shown statistically significant differences in hatchability when inbred and outbred. 
This observation is in accord with the reports of Jull (1929a) and of Warren (1934) to the effect that the greatest decrease in hatchability occurs when the coefficients of inbreeding range from zero to .125. The females with an inbred origin in both years have shown differences in hatchability following further inbreeding as compared to outbreeding, but these differences were not statistically significant.

Outbred females are heterozygous for a large number of genes. Some of these genes may affect hatchability. When such females are used in inbred matings the result is possibly a number of zygotes homozygous for some of the genes with a deleterious effect on hatchability. Inbred females, being already homozygous for a number of desirable genes affecting hatchability, since they are the surviving zygotes that did not carry homozygous deleterious genes, are less likely than outbred females to produce gametes with deleterious genes. Consequently further inbreeding may not lead to a significant decrease in hatchability.

Another important observation made in this study is that no significant differences in hatchability were observed in 1941 between levels of inbreeding. This observation is not in complete agreement with a report of Jull (1929b) who observed a decrease in hatchability as the coefficient of inbreeding increased.

The origins of the females influenced hatchability while those of the males did not. In both years the females with an inbred origin gave lower hatchability than those with an outbred origin but the differences were not found to be statistically significant. Hatchability was observed to be much more variable in eggs from inbred females than in eggs from outbred females.

A periodic decline in hatchability was observed in both years but it was found to be statistically significant only in 1941. This can only be explained by variations in environmental factors which remain unknown so far as this study is concerned.

A significant relation was observed between rate of egg production and hatchability in 1941 but not in 1940. In the latter year, the analysis was extended within origins of females and the relation remained without significance. Byerly, Titus and Ellis (1933) and Funk (1934, 1939) found a significant correlation between current egg production and hatchability. The relation between current egg production and hatchability is more complex than generally assumed, as has been pointed out by Byerly, Titus and Ellis (1933). While it may be explained in part by the effect of the diet on both egg production and hatchability, it may also be the result of length of interval between eggs or the length of time required for egg formation. This latter point would lead us to the relation between the stage of embryonic development reached in the egg at the time of oviposition and hatchability. This topic will be dealt with in another part of this study.

Significant differences in the hatchability of eggs from different clutch positions exist. Eggs in first clutch position hatehed less well than eggs in intermediate clutch positions but the difference was not statistically significant. Eggs occupying the last clutch position gave a significantly lower hatchability than those occupying intermediate clutch positions. There was no sig- 
nificant difference between the hatchability of eggs occupying the first and those in the last clutch positions although the latter hatched slightly poorer than the former. These findings are contrary to the observations of Funk (1939) that the order of eggs within a clutch has no bearing on their hatchability. Rendel (1943) also reported that in ducks the position of an egg in a clutch does not affect its chance of hatching.

The eggs laid early in the morning, before 8 o'clock, and late in the afternoon, after 2 o'clock, hatched less well than those laid between those hours. The differences were statistically significant except for the eggs occupying first clutch position. Contradictory reports are available on the relation between hour of day eggs are laid and their hatchability. Hutt and Pilkey (1930), Patterson (1930), Pritzker (1940), and McNally and Byerly (1936) have reported that eggs laid in the morning hatched better than eggs laid in the afternoon, while Funk (1934) concluded the reverse, that afternoon eggs hatched slightly better than morning eggs. Nicolaides (1933) found no statistically significant difference in the hatchability of eggs laid at different hours of the day although his data show that the eggs laid between 7 and 9 o'clock in the morning and between 2 and 6 o'clock in the afternoon did not hatch as well as those laid between 9 o'clock in the morning and noon. The data available in the present study are thus in agreement with those reported by Nicolaides. The statistical analysis in the present study, however, has revealed significant differences in the hatchability of early morning and late afternoon eggs when compared with eggs laid between 8 and 2 o'clock.

The eggs in first clutch position with a time interval of less than 42 hours and of more than 43 hours did not hatch as well as eggs with a time interval of 42 and 43 hours but the differences were not statistically significant. The eggs in clutch positions subsequent to the first with a time interval of 23 hours or less and 27 hours or more did not hatch as well as those with a time interval varying between 23 and 27 hours. The differences were found to be statistically significant. McNally and Byerly (1936) have noted that the best hatchability was observed in eggs with a time interval of approximately 27 hours. They observed an increase in hatchability as the time interval increased from 24 to 27 hours and a decrease in hatchability as the time interval increased over 27 hours. Hays (1936) obtained evidence that eggs with intervals of 241/2 hours or less and of $271 / 2$ hours or more did not hatch as well as eggs with intervals of 25 to $26 \frac{1}{2}$ hours. Hays (1938) also reported that as the time interval between clutches lengthened there was a tendency for hatchability to decline. The results of the present study are thus in accord with these observations of McNally and Byerly (1936) and Hays (1936, 1938) on the existence of a curvilinear relation between time interval and hatchability.

\section{SUMMARY}

The results of this study on hatchability, based on observations made during two years on matings of females with an inbred, an outbred and inbredcrossbred origin to males of the same three origins, indicate that inbreeding of outbred females (from $\mathrm{F}=0$ to $\mathrm{F}=.25$ ) resulted in decreased hatchability 
while further inbreeding of inbred females did not lead to any significant decrease in hatchability. The inbred females showed lower hatchability than the outbred females, whatever the system of mating, but the differences observed were not statistically significant. In one year, the birds laying at a higher intensity produced eggs that hatched better. The fertile eggs laid before 8 o'clock in the morning and after 2 o'clock in the afternoon did not hatch as well as those laid between those hours. The eggs that required 23 hours or less and 27 hours or more for their formation did not hatch as well as those that required between those hours. Premature and delayed oviposition apparently result in decreased hatchability. Eggs occupying a clutch position intermediate between the first and the last hatched significantly better than the eggs occupying the first and the last clutch position. 


\section{The Relative Effects of Inbreeding and Outbreeding on Reproduction in the Domestic Fowl}

\section{PAUL E. BERNIER, LEWIS W. TAYLOR, and C. A. GUNNS}

\section{EARLY EMBRYONIC GROWTH}

The Domestic Fowl has been a favorite material for studies on growth, as can be gathered from Lerner's review of the literature (1937). As a result, much progress has been made in the analysis of the environmental factors influencing size, as well as in the study of the genetic differences that exist between and within breeds. The majority of these studies have, however, been made during the post-embryonic growth period; comparatively few, omitting the purely descriptive ones, deal with the embryonic period and these few all deal with stages beyond the 72-hour stage of incubation.

Embryologists, until the latter part of the nineteenth century, were mostly concerned with purely descriptive studies and paid little attention to variability during early development. As pointed out by Mehnert (1896) only typical observations were considered and all variations were thought to be unimportant, accidental, unusual, or even aberrations. With the improvement of technique, the adoption of standard measurements, and the observation of large numbers of specimens, it soon became evident to most investigators that variability was of great importance in embryology and in fact of much value in their studies. This became particularly evident in experimental embryology, since its object is the study of embryological processes through natural or artificial variations in the developing organisms or in their environment.

The present study was undertaken in an effort to fill a gap in our knowledge of early embryonic growth in the domestic fowl by an analysis of the relative effects of genetical and environmental factors on the variability present in the very early stages of development. The events leading to this study were related in Part I. In addition to theoretical aspects, this study has practical aspects as well, such as the relation of the rate, and of the stage of development, before and at the beginning of incubation, to hatchability or embryonic mortality. In fact these practical aspects led to the initiation of the observations reported upon here and the theoretical aspects came into consideration as the investigation proceeded.

\section{Review of Literature}

The investigations made on the variability of the early embryonic growth rate in species of birds other than the domestic fowl indicate that differences in rate of development in early stages are difficult to detect, especially in closely related species. The genetic differences accounting for the specific 
differences in size would enter into play only as development attains relatively advanced stages. The outstanding investigations on the comparative rate of embryonic growth in various species of birds are those of Levi $(1922,1925)$, Kaufman (1927, 1929, 1930a, b, c), and Price (1938).

A number of investigators have studied the early embryonic development of different breeds and varieties of the domestic fowl. Keibel and Abraham (1900) and Keibel (1904) could not observe any noticeable difference in the size of embryos of Brown Leghorns and bantam hens, and they combined the data obtained from the two breeds. Byerly (1930) observed no difference in the size of embryos in two breeds varying in adult size. He later (1932) reported that the major differences in embryo size in different breeds and their hybrids could be satisfactorily explained by differences in egg size and that the inherent growth rate is probably identical for all breeds. Henderson (1930) made observations on embryonic growth in the Dark Cornish and the Single Comb White Leghorn breeds and reported little, if any, consistent difference in the weight of the embryos from the fourth day on. Rensch (1923) could not detect any difference between embryos of different breeds prior to the tenth day of incubation, but after that day the embryos of the larger breed were found to contain more and larger cells so that cell size and rate of cell proliferation were thought to be the causes of the differences in size between chick embryos in breeds differing in size. Keller (1933) found that embryo size in large and bantam breeds differed only after the first week of incubation and that there was no difference in the size of cells but only in the number of cells.

Blunn (1934) and Blunn and Gregory (1935) compared embryonic development in carefully paired eggs of Single Comb White Leghorn and Single Comb Rhode Island Red hens and observed that the embryos of the latter breed contained more and smaller cells. They concluded that there was a genetic difference in the rate of cell proliferation between the two breeds during embryonic development.

Kaufman (1936) compared the embryonic development of Polish Greenfoot and Silkie embryos as well as of their reciprocal hybrids. She observed that the pure Polish Greenfoot embryos were significantly larger than the crossbred embryos in eggs of the same size at eleven days of age. The Silkie embryos appeared to have their growth inhibited in the second week of incubation. She also observed differences in the proportion of parts to the whole in the Polish Greenfoot, Silkie, and reciprocal hybrids and interpreted these differences as evidence for the genetical control of embryonic growth and not merely as an effect of the amount of available food.

Byerly, Helsel and Quinn (1938) compared the development of Silkie, Rhode Island Red and their reciprocal hybrids. They concluded that the differences attributable to genetic factors are small and appear only after the first week of incubation. Egg size was found to be a more important factor in determining embryo size. They found no evidence of inherent differences in rate of cell division in embryos differing genetically in size although they observed that variability was greater in embryos from different matings than from those in the same mating. 
Derrick (1937) observed that embryos of the White Leghorn breed were frequently smaller than those of the Barred Plymouth Rock breed, at least during the first three days of incubation, but she did not submit her data to any statistical analysis to establish whether or not the difference was significant.

Thus, there is evidence in favor of the hypothesis that genetic factors influence the early embryonic development of the chick, although this evidence is contradictory in nature. The genetic factors apparently do enter into play after development has proceeded to a certain stage, approximately the second week of incubation. There is, however, the possibility that genetic factors enter into play at an earlier period, but that variability is so great that difficulty is experienced in ascribing any portion of such variability to genetic factors. Under such conditions it would be necessary to make a large number of observations on embryos from a large number of matings and under conditions of a planned experimental design which would allow the use of statistical methods. This was done in the present investigation.

\section{Materials and Methods}

The main object of this study was to determine the influence of genetic factors on early embryonic growth, hence no steps were taken to control genetic variation except to employ suitable statistical methods to measure it as accurately as possible. The length of time that embryos were under favorable temperature conditions for development is undoubtedly the most important source of variation that had to be controlled, or at least measured accurately, in order to make statistical adjustments. In the general introduction it was stated that eggs were collected hourly and kept in a refrigerated cabinet. No significant variation can be attributed to development occurring after the egg was laid and before it was incubated. The only remaining source of variation as to the time that the eggs were under conditions favorable to embryonic development is thus the period between ovulation and oviposition. The measurement of this period of time is dependent upon the time ovulation and fertilization occur in relation to oviposition, as well as the time required for the egg to descend through the oviduct. Warren and Scott (1934) were able to establish that ovulation normally occurs within one hour after laying of the immediately preceding egg of the clutch, while Olsen (1942) has observed that the egg is normally fertilized, in the infundibulum, within fifteen minutes after ovulation. The time interval between successive eggs of a clutch can therefore be accepted as a relatively accurate measurement of the time eggs are under conditions favorable to embryonic development before laying.

The two measurements of early embryonic growth used in these investigations were maximum diameter of the blastoderm in the unincubated egg and the number of somites present in the embryo after 38 hours of incubation. The first measurement is actually the only one that can be readily used in view of the relatively undifferentiated stage of the blastoderm at that time. The use of number of somites could be questioned, however, as there is no apparent reason to assume that the number of somites, which are presumably the result of differentiation, bears a definite relation to the size of the whole 
embryo. This question was important in these investigations since a satisfactory index of size, preferably one with a linear relation with size, was needed. Very fortunately a study on variability in the early development of duck embryos made by Fischel (1896) provided suitable data for verification of the assumption. Among all the data he reported on, for a total of 104 duck embryos, two measurements, total length of embryo and number of somites were used. Analysis of his data showed a correlation coefficient of .91 between number of somites and total length of embryo and the regression of total length of embryo on number of somites was found to be $82.16+4.65 \times$ somites. There is thus good evidence that the number of somites is a valid measurement of embryo size in the early stages of development.

\section{Analysis of Observations}

Before proceeding to a detailed analysis of the data collected in 1940 and 1941 on early embryo size as influenced by inbreeding and outbreeding, it was thought advisable to study the frequency distribution of early embryos as to size and the possible relation between early embryo size and factors such as: position the eggs occupy within a clutch, time interval or length of time elapsing between the oviposition of two successive eggs, and hour of lay. In addition to the data collected in the course of the present investigations in 1940 and 1941, Professor Taylor was kind enough to place at the disposal of the authors data he had collected on blastoderm size and on number of somites during the periods 1930-1938 and 1937-1938 respectively. Measurements on a total of 1677 blastoderms and somite counts on a total of 1163 embryos were available for analysis.

\section{Frequency Distributions of Blastoderms as to Maximum Diameter and of Embryos According to Number of Somites}

The observations on blastoderm size, as measured by their maximum diameter to the nearest hundredth of a millimeter, were grouped in classes of one-tenth of a millimeter. The measurements between .01 and $.10 \mathrm{~mm}$ were grouped together to give classes with mid-values of $.05 \mathrm{~mm}$. Figure 1 gives the frequency distribution of the 1677 blastoderms as to maximum diameter. The statistics obtained in the analysis and describing the frequency distribution are :

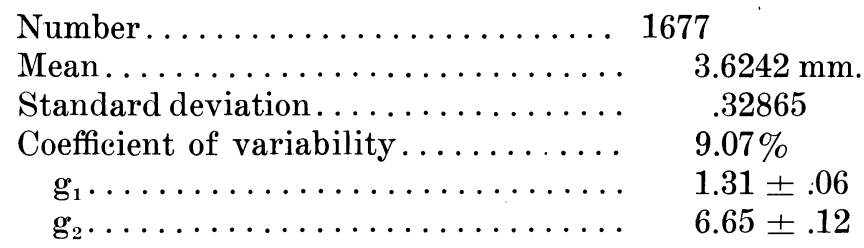

The mean and the standard deviation were used to calculate the expected frequency distribution superimposed (broken line) on the observed frequency distribution in figure 1. A test of goodness of fit gave a $\chi^{2}$ value of 99.06 with a probability point of less than .0001 . The observed distribution clearly 
deviates from a normal one. Inspection of figure 1 reveals the presence of leptokurtosis, an excess of observations near the mean, and positive skewness, the mode being smaller than the mean. These facts are confirmed by the statistics $\mathrm{g}_{1}$ and $\mathrm{g}_{2}$, which are respectively measures of skewness and kurtosis, computed from the third and fourth moments, or powers of the deviations from the mean, in the observed frequency distribution. The positive skewness of the observed frequency distribution, as compared to the expected, is the result of an excessively large number of blastoderms with a large diameter. There is thus very good evidence to conclude that the very large blastoderms

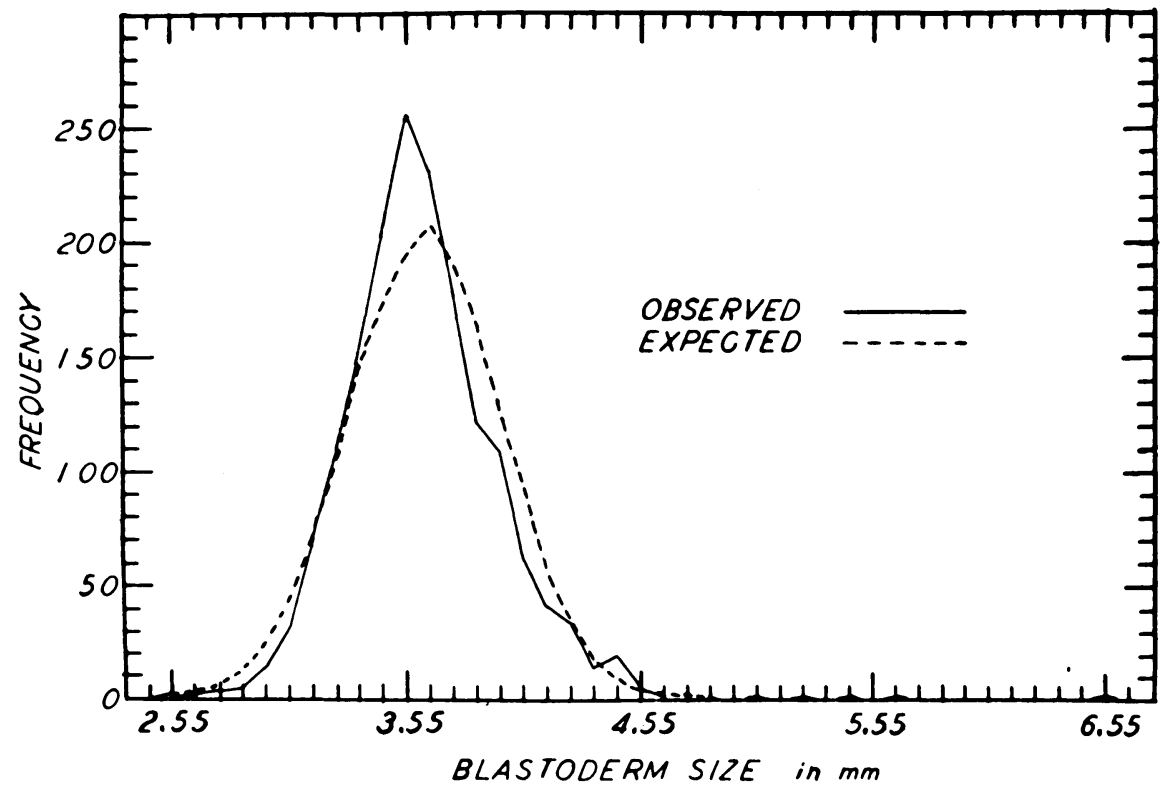

Fig. 1

were observed more frequently than would be expected. The frequency of the very large blastoderms is high enough to suspect their occurrence is due to recurring conditions.

The frequency distribution of somite counts made in 1937, 1938, 1940 and 1941 is given in figure 2. The statistics obtained in the analysis are :

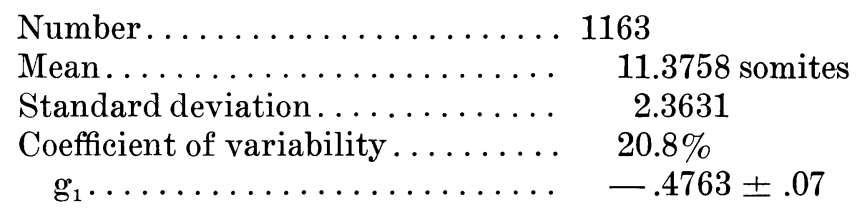

The form of the graph indicates negative skewness which is confirmed by the statistic $g_{1}$. The frequency of low somite counts is excessive; it is logical to assume that these low somite counts were made on abnormal embryos, 
dead or moribund, that probably do not belong to a normal distribution. It was therefore decided that within every bird, the extremely low somite counts (those that were four units below the mean for that bird) should be discarded ; this criterion of rejection corresponds to twice the standard deviation.

\section{Relation Between Clutch Position of Eggs and Early Embryo Size}

The data on the relation between clutch position of eggs and the size of the blastoderm they contained are summarized in table 23.

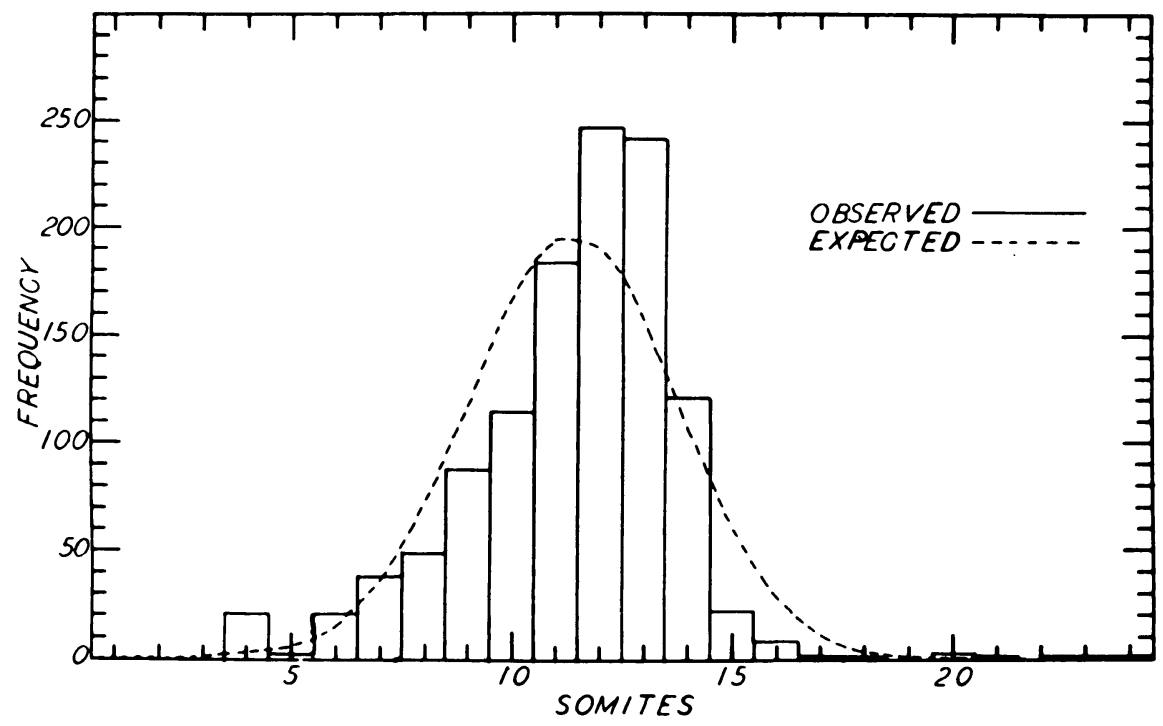

Fig. 2

The larger size of blastoderms in first clutch position is particularly striking, as is also the greater variability. There is evidence that eggs occupying second clutch position also contained a larger blastoderm than eggs occupying clutch positions subsequent to the second although the variability in this case is not greater than that for eggs in subsequent clutch positions.

Tests of homogeneity of the distributions of blastoderms classified according to deviation below and above the median and clutch position of eggs have given the results reported in table 24 . The distribution in clutch positions one to five is heterogeneous and eggs in first and second clutch positions apparently contribute most to the heterogeneity. A comparison of the distribution of eggs in first clutch position and of the total number of eggs in clutch positions subsequent to the first also shows heterogeneity. The elimination of eggs occupying first clutch position gives a distribution which still shows heterogeneity. The distribution of eggs occupying second clutch position compared to that of the total number of eggs occupying clutch positions subsequent to the second also shows heterogeneity. These tests show that 
TABLE 23

RELATION BETWEEN CLUTCH POSITION OF EGGS AND BLASTODERM SIZE, DATA OF 1937, 1938, 1940, AND 1941

\begin{tabular}{|c|c|c|c|}
\hline Clutch position & $\begin{array}{l}\text { Number of } \\
\text { blastoderms }\end{array}$ & $\begin{array}{l}\text { Mean size } \\
\text { in } \mathrm{mm}\end{array}$ & $\begin{array}{l}\text { Standard } \\
\text { deviation }\end{array}$ \\
\hline 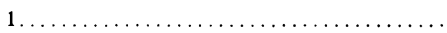 & 582 & 3.7761 & .3825 \\
\hline 2. & 462 & 3.5801 & .2701 \\
\hline $3 \ldots$ & 269 & 3.5101 & .2631 \\
\hline $4 \ldots \ldots \ldots \ldots \ldots \ldots$ & 136 & 3.5265 & .2571 \\
\hline $5+\ldots \ldots \ldots \ldots \ldots \ldots \ldots \ldots \ldots \ldots \ldots$ & 227 & 3.5108 & .2413 \\
\hline All positions...... & 1676 & 3.6242 & .3287 \\
\hline 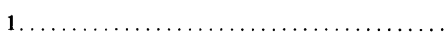 & 582 & 3.7761 & .3825 \\
\hline $2+\ldots \ldots \ldots \ldots \ldots \ldots \ldots \ldots \ldots \ldots \ldots \ldots \ldots \ldots \ldots \ldots \ldots \ldots$ & 1094 & 3.5431 & .2626 \\
\hline All positions. . & 1676 & 3.6242 & .3287 \\
\hline
\end{tabular}

TABLE 24

TESTS OF HOMOGENEITY OF THE DISTRIBUTION OF BLASTODERMS

IN EGGS OCCUPYING VARIOUS CLUTCH POSITIONS AND

CLASSIFIED ACCORDING TO DEVIATION BELOW

OR ABOVE MEDIAN DIAMETER

\begin{tabular}{|c|c|c|c|c|c|c|c|c|}
\hline \multirow{2}{*}{$\begin{array}{l}\text { Above or below median } \\
\text { blastoderm size }\end{array}$} & \multicolumn{5}{|c|}{ Clutch position of eggs } & \multirow[t]{2}{*}{ Total } & \multirow{2}{*}{$x^{2}$} & \multirow[t]{2}{*}{$\mathbf{P}$} \\
\hline & 1 & 2 & 3 & 4 & $5+$ & & & \\
\hline Below.... & 190 & 257 & 179 & 83 & 146 & 855 & & \\
\hline Above.... & 392 & 205 & 90 & 53 & 81 & 821 & & \\
\hline Total. . & 582 & 462 & 269 & 136 & 227 & 1676 & 129.99 & .001 \\
\hline & 1 & $2+$ & & & & & & \\
\hline Below ....... & 190 & 665 & $\ldots$. & $\ldots$. & $\ldots$ & 855 & & \\
\hline Above...... & 392 & 429 & $\ldots$ & $\ldots$ & $\ldots$ & 821 & & \\
\hline Total . ............. & 582 & 1094 & $\ldots$ & $\ldots$ & $\ldots$ & 1676 & 119.25 & .001 \\
\hline & & 2 & 3 & 4 & $5+$ & & & \\
\hline Below....... & $\cdots$ & 178 & 136 & 65 & 99 & 478 & & \\
\hline Above...... & $\ldots$ & 284 & 133 & 71 & 128 & 616 & & \\
\hline Total. & $\ldots$ & 462 & 269 & 136 & 227 & 1094 & 11.09 & $.01-.02$ \\
\hline & & 2 & $3+$ & & & & & \\
\hline Below.. & $\ldots$ & 178 & 300 & $\ldots$ & $\ldots$ & 478 & & \\
\hline Above $\ldots \ldots \ldots \ldots \ldots$ & $\ldots$ & 284 & 332 & $\ldots$ & $\ldots$ & 616 & & \\
\hline Total. & $\ldots$ & 462 & 632 & $\ldots$ & $\ldots$ & 1094 & 8.31 & .004 \\
\hline
\end{tabular}


blastoderms varied significantly in size in eggs occupying different clutch positions, particularly in the first and second clutch positions.

The combined data of 1937, 1938, 1940 and 1941 were analyzed to study the relation between the position of eggs within a clutch and the stage of development reached by the embryos after 38 hours of incubation as measured by number of somites. Table 25 gives the statisties of samples in clutch positions 1 to 5 with the latter position also including all the data in clutch positions subsequent to 5 .

The mean number of somites varies according to the position the egg occupies in a clutch and the difference in mean number of somites is especially marked when eggs in first clutch position are compared with eggs in subse-

TABLE 25

STATISTICS ON NUMBER OF SOMITES PRESENT AFTER 38 HOURS OF INCUBATION IN EGGS OCCUPYING DIFFERENT CLUTCH POSITIONS

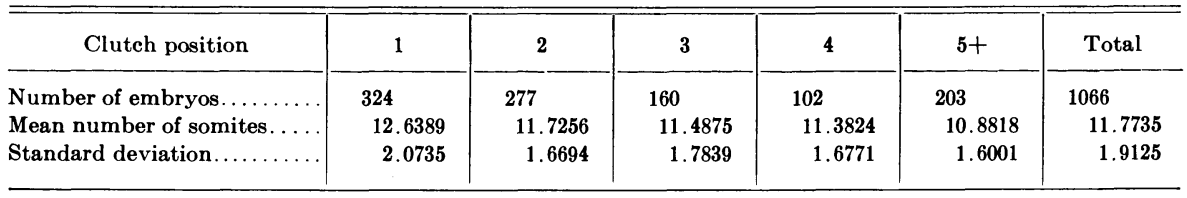

quent clutch positions. Eggs occupying first clutch position also show more variability in mean number of somites than eggs in subsequent clutch positions.

Tests of homogeneity of the distribution of embryos as to number of somites in eggs occupying first clutch position as compared to eggs in subsequent positions, and in second clutch position eggs as compared to eggs in subsequent positions, have given the results presented in table 26 . These tests of homogeneity reveal that the distribution of embryos according to number of somites is significantly different in eggs occupying first clutch position than in eggs occupying subsequent clutch positions. The distribution in eggs occupying second clutch position is also significantly different when compared with the distribution of embryos in eggs occupying subsequent clutch positions.

\section{Relation Between Time Interval Between Eggs and Early Embryo Size}

A study was made of the relation between the length of the time interval between eggs and early embryo size on the data available for 1937, 1938, 1940 and 1941.

The results of the analysis of the data on blastoderm size are presented in table 27. A separate analysis was made for eggs occupying first clutch position and for those in subsequent clutch positions.

Eggs in first clutch position, as already demonstrated, show more variability in blastoderm size and do so particularly when the time interval is 43 hours or less and 48 hours or more.

In eggs occupying clutch positions subsequent to the first, there is a slight tendency towards an increase in blastoderm size with an increase in length 
of time interval between eggs. This trend is more marked for intervals of 26 to 30 hours. Eggs in clutch positions subsequent to the first also show less variability in blastoderm size than eggs in first clutch position.

Tests of homogeneity of the distribution of eggs classified according to first and subsequent clutch positions, time interval and deviation from the median blastoderm size gave the results presented in table 28 .

TABLE 26

TESTS OF HOMOGENEITY OF THE DISTRIBUTION OF EMBRYOS AS TO NUMBER OF SOMITES IN EGGS OCCUPYING VARIOUS CLUTCH POSITIONS

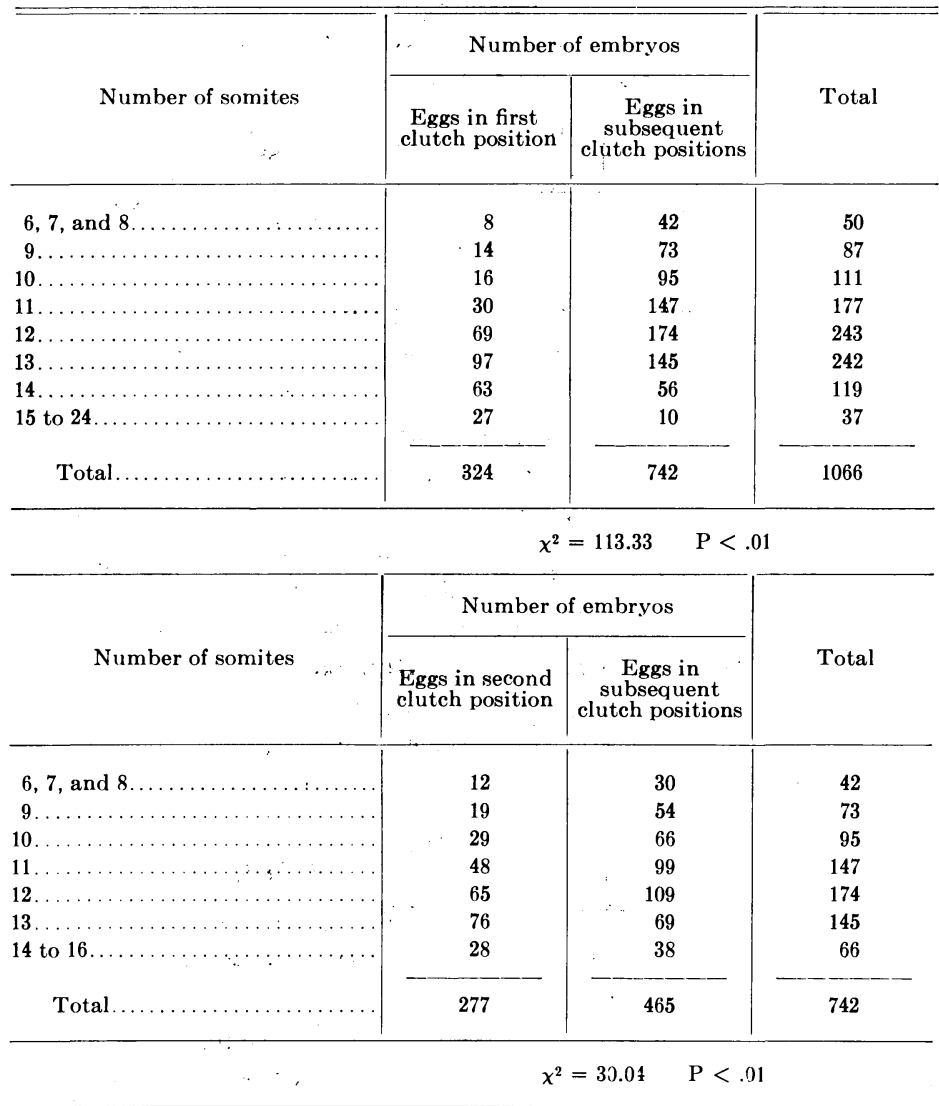

The tests of heterogeneity reveal that eggs in first elutch position show no significant variation in blastoderm size when classified according to time interval. This lack of significant relation is probably accounted for by the inaccuracy of the time interval between clutches as an index of the actual time spent by the egg in the oviduct. Eggs in clutch positions subsequent to the first do show significant variations in blastoderm size when classified accord- 
TABLE 27

RELATION BETWEEN TIME INTERVAL

AND BLASTODERM SIZE

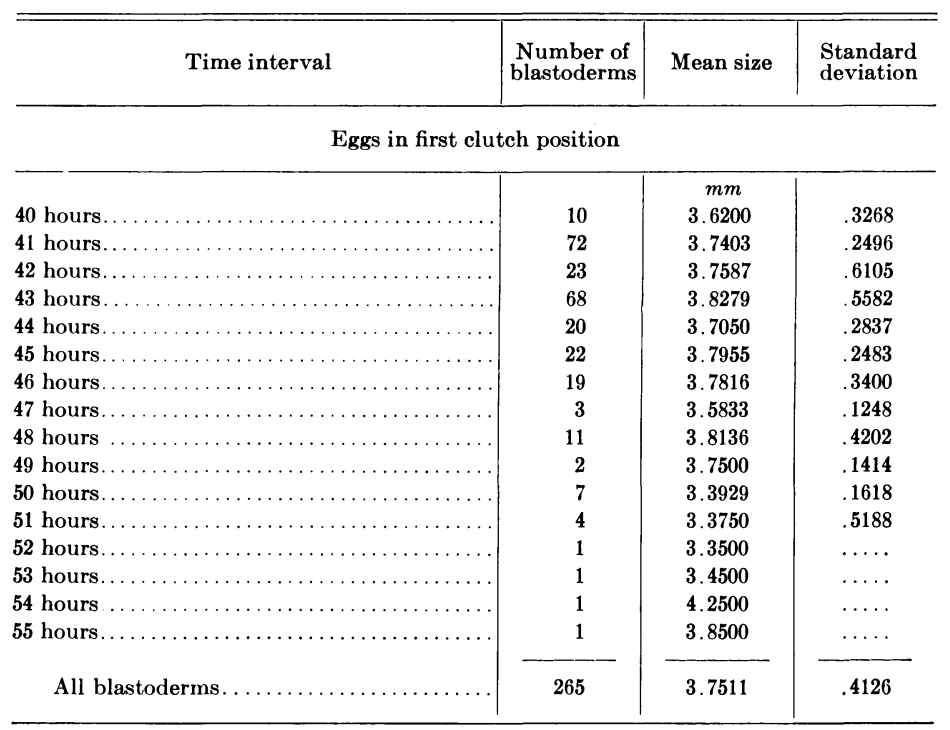

Eggs in subsequent clutch positions

\begin{tabular}{|c|c|c|c|}
\hline 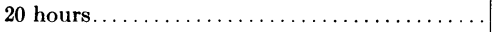 & 1 & 2.9500 & $\ldots \ldots$ \\
\hline 21 hours $\ldots \ldots \ldots \ldots \ldots \ldots \ldots \ldots$ & 7 & 3.5071 & .2494 \\
\hline 22 hours. . . . . $\ldots \ldots \ldots \ldots \ldots \ldots$ & 6 & 3.5000 & .2121 \\
\hline 23 hours...... & 37 & 3.4338 & .2467 \\
\hline 24 hours $\ldots \ldots \ldots \ldots \ldots \ldots \ldots$ & 139 & 3.5104 & .2125 \\
\hline 25 hours..................... & 69 & 3.4558 & .2345 \\
\hline 26 hours........... & 192 & 3.5193 & .2418 \\
\hline 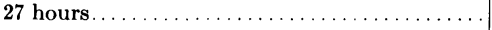 & 110 & 3.5291 & .2378 \\
\hline 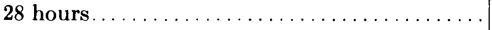 & 58 & 3.5586 & .2319 \\
\hline 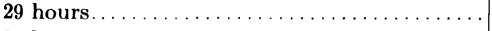 & 44 & 3.5727 & .2587 \\
\hline 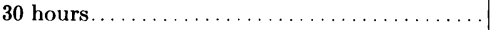 & 8 & 3.7000 & .3817 \\
\hline 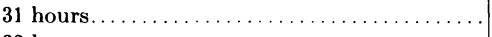 & 5 & 3.6300 & .3033 \\
\hline 32 hours. . . . . . . . . . . . . . . . . . . . & $\cdots$ & $\ldots \ldots$ & $\cdots \cdots$ \\
\hline 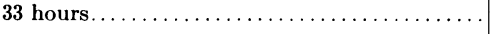 & 1 & 3.9500 & $\cdots \cdots$ \\
\hline All blastoderms............ & 677 & 3.5172 & .1863 \\
\hline
\end{tabular}

ing to time interval. This relation can be interpreted as evidence that, in eggs occupying a clutch position subsequent to the first, time interval between eggs is a reliable index of the actual time spent by the egg in the oviduct.

The data on number of somites present after 38 hours of incubation were also analyzed for the possible relation between time interval and number of somites. In view of the indicated relative inaccuracy of the time interval for eggs occupying first clutch position, the analysis was limited to eggs in clutch positions subsequent to the first. Table 29 gives the mean number of somites observed in embryos in eggs with different time intervals.

The relation between time interval and mean number of somites is very 
TABLE 28

TESTS OF HOMOGENEITY OF THE DISTRIBUTION OF EGGS

CLASSIFIED ACCORDING TO CLUTCH POSITION,

TIME INTERVAL AND DEVIATION FROM

THE MEDIAN BLASTODERM SIZE

\begin{tabular}{|c|c|c|c|c|c|c|c|c|c|}
\hline \multirow{2}{*}{$\begin{array}{l}\text { Above or below median } \\
\text { blastoderm size }\end{array}$} & \multicolumn{8}{|c|}{ Time interval in hours } & \multirow{2}{*}{ Total } \\
\hline & $40-41$ & 42 & 43 & 44 & 45 & 46 & $47-48$ & $49-55$ & \\
\hline \multicolumn{10}{|c|}{ Eggs in first clutch position } \\
\hline Below. . & 28 & 12 & 21 & 7 & 4 & 5 & 5 & 9 & 91 \\
\hline Above. & 54 & 11 & 47 & 13 & 18 & 14 & 9 & 8 & 174 \\
\hline Total. . & 82 & 23 & 68 & 20 & 22 & 19 & 14 & 17 & 265 \\
\hline \multicolumn{10}{|c|}{$\chi^{2}=9.29$} \\
\hline \multirow{2}{*}{$\begin{array}{l}\text { Above or below median } \\
\text { blastoderm size }\end{array}$} & \multicolumn{8}{|c|}{ Time interval in hours } & \multirow{2}{*}{ Total } \\
\hline & $20-23$ & 24 & 25 & 26 & 27 & 28 & 29 & $30-33$ & \\
\hline \multicolumn{10}{|c|}{ Eggs in clutch positions subsequent to first } \\
\hline Below. & 41 & 89 & 51 & 125 & 78 & 34 & 24 & 5 & 447 \\
\hline Above. . & 10 & 50 & 18 & 67 & 32 & 24 & 20 & 9 & 230 \\
\hline Total.... & 51 & 139 & 69 & 192 & 110 & 58 & 44 & 14 & 677 \\
\hline \multicolumn{10}{|c|}{$\chi^{2}=17.83$} \\
\hline
\end{tabular}

TABLE 29

RELATION BETWEEN TIME INTERVAL IN EGGS OCCUPYING CLUTCH POSITIONS SUBSEQUENT TO THE FIRST AND NUMBER OF SOMITES

\begin{tabular}{|c|c|c|}
\hline Time interval in hours & $\begin{array}{c}\text { Number of } \\
\text { embryos }\end{array}$ & Mean somites \\
\hline 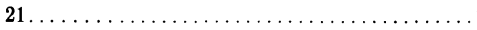 & 3 & 9.33 \\
\hline 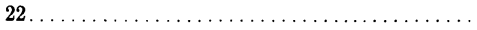 & 5 & 9.80 \\
\hline $23 \ldots$ & 43 & 10.42 \\
\hline $24 \ldots$ & 153 & 10.64 \\
\hline $25 \ldots \ldots \ldots$ & 97 & 10.94 \\
\hline $26 \ldots \ldots \ldots$ & 205 & 11.80 \\
\hline $27 \ldots$ & 121 & 11.59 \\
\hline 28 . & 54 & 12.28 \\
\hline $29 \ldots$ & 54 & 13.00 \\
\hline $30 \ldots \ldots \ldots$ & 7 & 13.00 \\
\hline Total. & 742 & $\ldots \ldots$ \\
\hline Average $\ldots \ldots \ldots \ldots \ldots \ldots \ldots \ldots \ldots \ldots \ldots$ & $\ldots \ldots$ & 11.4443 \\
\hline
\end{tabular}

striking. This relation is further supported by observations made on eight eggs in first clutch position which contained embryos with a large number of somites, i.e., from 16 to 24 somites. These observations led to the interpretation that these eight eggs were really in last elutch position and had been retained an abnormally long period of time in the oviduct. This is supported 
by the following facts. These eight eggs weighed less than the egg following them, were laid very early in the morning and were each followed by an egg also laid very early in the morning, and, finally, were in a longer clutch than the preceding or following ones. The time interval of these eight retained eggs also shows a good relation with number of somites as shown in table 30 .

TABLE 30

RELATION BETWEEN TIME INTERVAL AND

NUMBER OF SOMITES IN EIGHT

RETAINED EGGS

\begin{tabular}{c|c|c}
\hline \hline Time interval & $\begin{array}{c}\text { Number of } \\
\text { eggs }\end{array}$ & Mean somites \\
\hline 41 hours. $\ldots \ldots \ldots \ldots \ldots \ldots \ldots \ldots \ldots \ldots \ldots \ldots \ldots \ldots \ldots$ & 3 & 17.67 \\
43 hours. $\ldots \ldots \ldots \ldots \ldots \ldots \ldots \ldots \ldots \ldots \ldots \ldots \ldots$ & 2 & 20.00 \\
45 hours. $\ldots \ldots \ldots \ldots \ldots \ldots \ldots \ldots \ldots \ldots \ldots \ldots$ & 3 & 21.33 \\
\hline
\end{tabular}

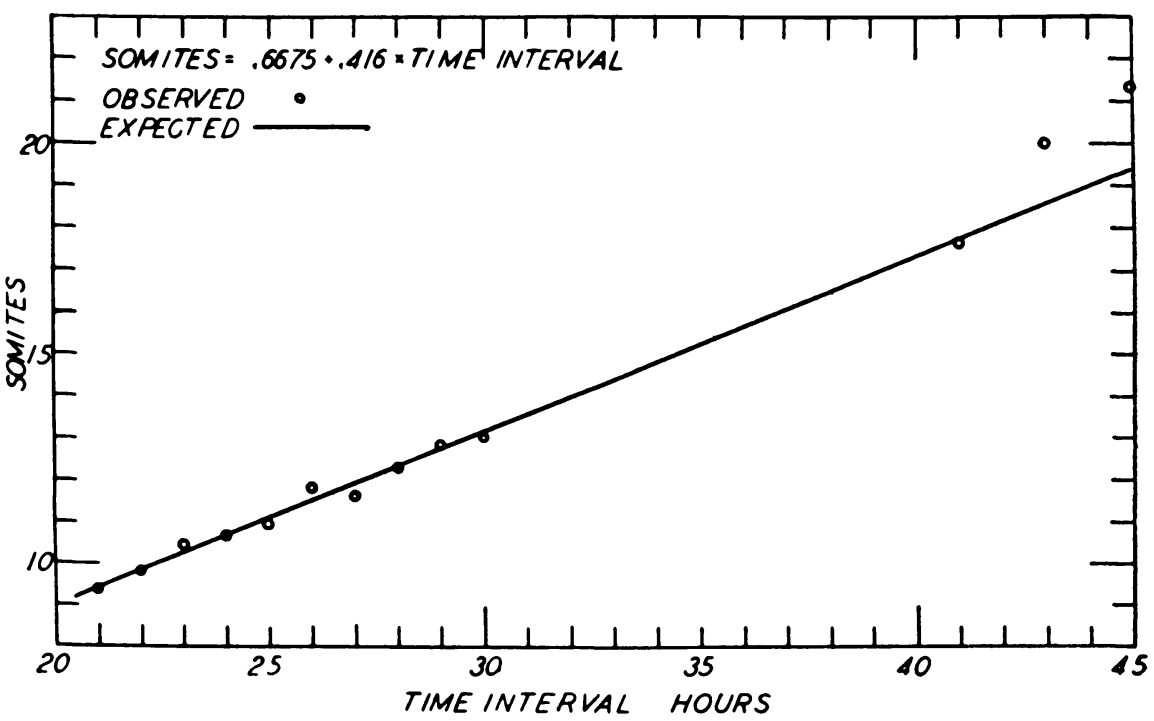

Fig. 3

An analysis of the regression of number of somites present in the embryos after 38 hours of incubation on time interval between eggs, including the data on the eight embryos with a large number of somites, has given the following regression equation:

$$
\text { Number of somites }=0.67+0.416 \times \text { time interval }
$$

The least square fit is illustrated by a straight line in figure 3 and the observed values (means of classes) are indicated by circles.

The analysis of the data on time interval and number if somites shows a positive relation between the two variables in eggs occupying a clutch position subsequent to the first. 


\section{Relation Between Clutch Position and Length of Time Interval Between Eggs}

In view of the results of the two preceding analyses, a study was made of the relation between clutch position and time interval (table 31 ).

Time interval apparently decreases with later clutch positions. A test of the homogeneity of the distribution of eggs in second and subsequent clutch

TABLE 31

RELATION BETWEEN CLUTCH POSITION

AND TIME INTERVAL

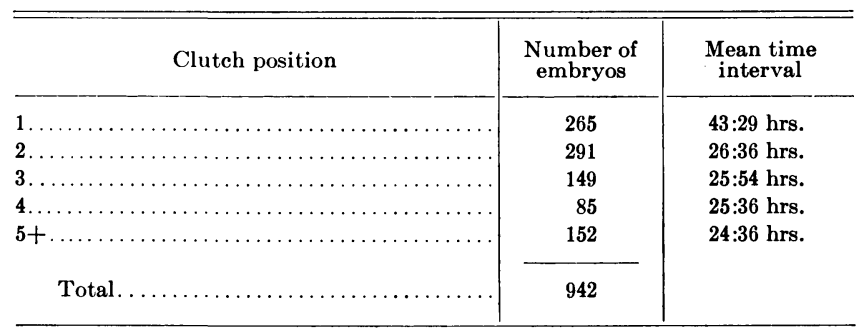

TABLE 32

RELATION BETWEEN TIME INTERVAL IN EGGS OCCUPYING SECOND CLUTCH POSITION AND SIZE OF CLUTCH

\begin{tabular}{|c|c|c|}
\hline Clutch size & $\begin{array}{c}\text { Number of } \\
\text { eggs }\end{array}$ & $\begin{array}{c}\text { Mean } \\
\text { time interval } \\
\text { between first and } \\
\text { second egg }\end{array}$ \\
\hline Two eggs...... & 181 & $28: 12 \mathrm{hrs}$. \\
\hline Three eggs..... & 115 & $26: 19 \mathrm{hrs}$. \\
\hline Four eggs.... & 75 & $25: 55 \mathrm{hrs}$. \\
\hline Five eggs. $\ldots \ldots \ldots \ldots \ldots \ldots \ldots \ldots \ldots \ldots$ & 33 & 25:04 hrs. \\
\hline Two to five eggs. . & 404 & $27: 00 \mathrm{hrs}$. \\
\hline
\end{tabular}

positions according to time interval has given a $\chi^{2}$ value of 60.19 with a probability of less than .01. The distribution is heterogeneous and eggs occupying second clutch position have a longer time interval than eggs in subsequent clutch positions. This relation between clutch position and time interval, however, may be spurious. Eggs in short clutches may have a longer time interval. These eggs may also have a disproportionately large representation in the total number of eggs studied and the result may be a longer time interval for elutch positions 2 and 3 as compared to clutch position 4 and subsequent ones. This hypothesis is supported by the data presented in table 32 showing the relation between time interval in eggs occupying second clutch position and size of clutch. 


\section{Interaction Between Time Interval and Clutch Position on Early Embryo Size}

The data gathered in 1940 and 1941 were submitted to a more detailed analysis of the relation between clutch position and early embryo size, taking into account length of time interval between eggs. The analysis of the data on blastoderm size is summarized in table 33 .

As observed previously in the combined data for 1937, 1938, 1940 and 1941, the eggs occupying first clutch position in 1940 and 1941 contained a larger blastoderm and also showed a higher variability in blastoderm size than eggs in either last or intermediate clutch positions.

TABLE 33

RELATION BETWEEN CLUTCH POSITION, TIME INTERVAL BETWEEN EGGS AND BLASTODERM SIZE

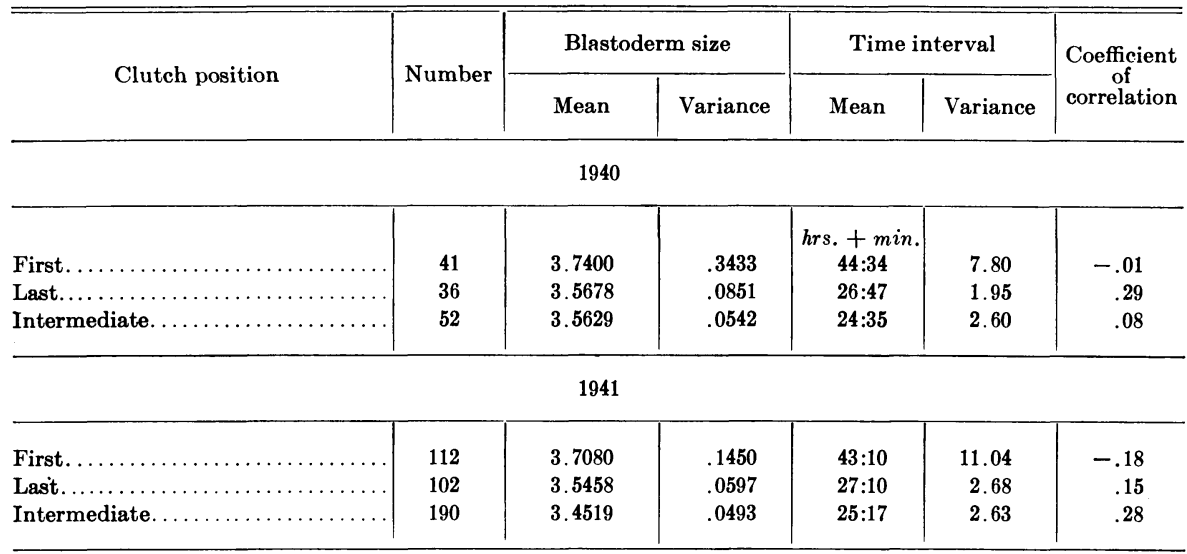

A very interesting finding is that eggs occupying the last clutch position in 1941 contained a larger blastoderm than eggs in intermediate clutch positions. However, when the last or second egg in two-egg clutches is eliminated, the mean size of blastoderms in last eggs for 1941 is reduced to $3.4933 \mathrm{~mm}$ as compared to 3.4519 for intermediate eggs. In 1940 the last eggs did not show a higher blastoderm size when compared to eggs in intermediate clutch positions.

In both 1940 and 1941, the time interval for eggs in the last clutch position was observed to be significantly higher than that for eggs in intermediate clutch positions. In 1941, even after eliminating the second or last egg in two-egg clutches, the time interval for last eggs was $26: 45$ hours as compared to 25:17 hours for eggs in intermediate clutch positions. The same significant difference was also observed in 1940. Since this longer time interval for last eggs in a clutch is not accompanied by a corresponding increase in blastoderm size, a delay in ovulation could very well explain part of the longer time interval between the last two eggs in a clutch. 
Eggs in two-egg clutches, as already intimated, contained blastoderms larger than the mean of the whole population and this is clearly demonstrated in table 34 .

In 1940 and 1941 respectively, second eggs in two-egg clutches had a time interval of $27: 42$ and $28: 15$ hours as compared to $25: 49$ and $25: 55$ hours for eggs in clutch positions subsequent to the first. Second eggs in two-egg clutches thus had a longer time interval than the average for all eggs in clutch positions subsequent to the first. The coefficients of correlation between time interval and blastoderm size in the last or second egg in two-egg clutches were found to be -.19 and -.01 for 1940 and 1941 respectively. These observa-

TABLE 34

BLASTODERM SIZE IN EGGS IN CLUTCHES OF TWO AS COMPARED TO THE SAMPLE AS A WHOLE BEFORE AND AFTER ELIMINATION OF CLUTCHES OF ONE AND TWO EGGS

\begin{tabular}{|c|c|c|c|c|c|c|c|}
\hline \multirow{2}{*}{ Size of clutch } & \multirow{2}{*}{$\begin{array}{l}\text { Clutch } \\
\text { position }\end{array}$} & \multicolumn{3}{|c|}{1940} & \multicolumn{3}{|c|}{1941} \\
\hline & & $\begin{array}{l}\text { Number of } \\
\text { blastoderms }\end{array}$ & $\begin{array}{c}\text { Mean } \\
\text { size }\end{array}$ & Variance & $\begin{array}{c}\text { Number of } \\
\text { blastoderms }\end{array}$ & $\begin{array}{c}\text { Mean } \\
\text { size }\end{array}$ & Variance \\
\hline Two eggs........ & First & 15 & 3.6840 & .8187 & 25 & 3.6152 & .0839 \\
\hline Two eggs........ & Second & 17 & 3.6576 & .1113 & 40 & 3.6270 & .0650 \\
\hline Both positions... & $\ldots \ldots$ & 32 & 3.6700 & .4274 & 65 & 3.6225 & .0711 \\
\hline All eggs............ & $\ldots \ldots$ & 129 & 3.6205 & .1588 & 403 & 3.5466 & .0897 \\
\hline $\begin{array}{c}\text { All eggs after elimi- } \\
\text { nation of clutches } \\
\text { of one and two } \\
\text { eggs............. }\end{array}$ & $\ldots \ldots$ & 88 & 3.5795 & .0689 & 322 & 3.5238 & .0888 \\
\hline
\end{tabular}

tions can be interpreted as evidence that time interval in two-egg clutches, as was the case for eggs in first clutch position, is not an accurate indication of the actual time spent by the egg in the oviduct, even though it is expressed in a larger blastoderm than that found in eggs from clutch positions subsequent to the first. The time interval between the first and second egg in two-egg clutches, although representing an actually longer interval of sojourn in the oviduct as manifested by a larger blastoderm, is also attributable in part to a delay in ovulation after the oviposition of the first egg.

The data collected on number of somites after 38 hours of incubation, during 1940 and 1941, were also submitted to a more detailed analysis to establish the relation between clutch position, time interval between eggs and number of somites. The available data are summarized in table 35 .

The eggs occupying first clutch position contain embryos with a larger mean number of somites than the eggs in either last or intermediate clutch positions. Eggs in first clutch position also have slightly higher variances for number of somites than eggs in intermediate clutch positions. The variances of time interval are also higher for eggs in first clutch position than for eggs in either last or intermediate clutch positions. This higher variance in 
time interval, however, does not explain the higher variance in number of somites, as indicated by the low and nonsignificant correlation observed between time interval and number of somites in eggs occupying first clutch position.

The eggs occupying last clutch position in 1941 showed a higher mean number of somites than the eggs in intermedate clutch positions. In 1940 there was no difference in the mean number of somites between eggs occupy. ing the intermediate and last clutch positions. The elimination of the second or last egg of two-egg clutches in 1941 reduced the mean number of somites in last eggs from 12.43 to 12.29 . The latter was still significantly higher than

TABLE 35

RELATION BETWEEN CLUTCH POSITION, TIME INTERVAL BETWEEN EGGS AND NUMBER OF SOMITES

\begin{tabular}{|c|c|c|c|c|c|c|}
\hline \multirow{2}{*}{ Clutch position } & \multirow{2}{*}{ Number } & \multicolumn{2}{|c|}{ Somites } & \multicolumn{2}{|c|}{ Time interval } & \multirow{2}{*}{$\begin{array}{l}\text { Coefficient } \\
\text { of } \\
\text { correlation }\end{array}$} \\
\hline & & Mean & Variance & Mean & Variance & \\
\hline \multicolumn{7}{|c|}{1940} \\
\hline $\begin{array}{l}\text { First. } \ldots \ldots \ldots \ldots \\
\text { Last } \ldots \ldots \ldots \ldots \ldots \ldots \ldots \ldots \ldots \ldots \\
\text { Intermediate } \ldots \ldots \ldots \ldots \ldots \ldots \ldots \ldots\end{array}$ & $\begin{array}{l}28 \\
39 \\
57\end{array}$ & $\begin{array}{l}11.79 \\
10.51 \\
10.56\end{array}$ & $\begin{array}{l}4.6929 \\
4.2563 \\
3.5446\end{array}$ & $\begin{array}{l}\text { hrs. }+ \text { min. } \\
44: 30 \\
26: 51 \\
25: 07\end{array}$ & $\begin{array}{l}5.00 \\
3.45 \\
1.97\end{array}$ & $\begin{array}{r}.11 \\
-.09 \\
.20\end{array}$ \\
\hline \multicolumn{7}{|c|}{1941} \\
\hline $\begin{array}{l}\text { First. } \ldots \ldots \ldots \ldots \ldots \\
\text { Last } \ldots \ldots \ldots \ldots \ldots \ldots \ldots \ldots \ldots \\
\text { Intermediate } \ldots \ldots \ldots \ldots \ldots \ldots \ldots \ldots\end{array}$ & $\begin{array}{l}146 \\
118 \\
202\end{array}$ & $\begin{array}{l}13.18 \\
12.43 \\
11.40\end{array}$ & $\begin{array}{l}5.2646 \\
3.3928 \\
2.9531\end{array}$ & $\begin{array}{l}42: 45 \\
27: 02 \\
25: 16\end{array}$ & $\begin{array}{l}4.15 \\
3.26 \\
2.05\end{array}$ & $\begin{array}{l}.04 \\
.22 \\
.25\end{array}$ \\
\hline
\end{tabular}

the mean (11.40) for eggs in intermediate clutch positions. In both 1940 and 1941 eggs occupying last clutch positions had a longer time interval than eggs in intermediate clutch positions. The time interval for last eggs was reduced from $27: 02$ to $26: 24$ hours following the elimination of the second or last egg in two-egg clutches; the latter time interval is still higher than that for eggs in intermediate clutch positions (25:16 hrs.). The last egg in a clutch, in 1941, apparently spent a longer period of time in the oviduct and the result was a larger mean number of somites. A positive correlation between number of somites and time interval of last eggs was observed in 1941 but not in 1940. This correlation was of the same order as that within eggs occupying intermediate clutch positions.

The correlation coefficients between time interval and number of somites, given in table 35, are higher for eggs occupying intermediate clutch positions than for eggs occupying first clutch position. This observation lends further support to the conclusion suggested previously, that time interval is a better indication of actual time spent in the oviduct for eggs in intermediate clutch positions than for eggs in first clutch position; this is the result of relatively better synchronization between oviposition of the preceding egg and ovulation of the one on which observations are made. 
In view of the larger blastoderm and higher number of somites observed in eggs belonging to one- and two-egg clutches, it was thought that possibly a general relation existed between size of clutch and early embryo size. Measurements on blastoderms and on number of somites were classified according to size of clutches as summarized in table 36 .

No appreciable difference in early embryo size could be detected except in the case, already demonstrated, of clutches of one and two eggs. An analysis of variance (table 37) was made to establish the significance of the differences

TABLE 36

SUMMARY OF DATA ON RELATION BETWEEN SIZE OF CLUTCH AND EARLY EMBRYO SIZE

\begin{tabular}{|c|c|c|c|c|}
\hline \multirow{2}{*}{ Size of clutch } & \multicolumn{2}{|c|}{ Mean blastoderm size } & \multicolumn{2}{|c|}{ Mean somites } \\
\hline & 1940 & 1941 & 1940 & 1941 \\
\hline $1 \ldots \ldots \ldots \ldots \ldots \ldots \ldots$ & 3.8456 & 3.6894 & 13.0 & 13.0 \\
\hline $2 \ldots \ldots \ldots \ldots \ldots \ldots$ & 3.6700 & 3.6225 & 10.3 & 12.9 \\
\hline $3 \ldots \ldots \ldots \ldots \ldots \ldots$ & 3.5604 & 3.5404 & 10.5 & 12.3 \\
\hline $4 \ldots \ldots \ldots \ldots \ldots \ldots$ & 3.3880 & 3.5760 & 11.0 & 12.3 \\
\hline $5 \ldots \ldots \ldots \ldots \ldots \ldots$ & 3.6567 & 3.5490 & 10.4 & 12.2 \\
\hline $6 \ldots \ldots \ldots \ldots$ & 3.7136 & 3.5200 & 11.8 & 12.2 \\
\hline $7 \ldots$ & 3.1900 & 3.4758 & 9.0 & 12.2 \\
\hline 8. & 3.5917 & 3.4580 & 12.5 & 10.7 \\
\hline $9 \ldots$ & 3.3200 & 3.3609 & 11.0 & 11.8 \\
\hline $10 \ldots \ldots \ldots$ & 3.2967 & 3.4550 & $\ldots$ & 11.0 \\
\hline $11 \ldots \ldots \ldots \ldots \ldots \ldots \ldots$ & $\ldots \ldots$ & $\ldots \ldots$ & $\ldots$ & $\ldots$ \\
\hline $12 \ldots \ldots \ldots \ldots \ldots \ldots \ldots$ & 3.5850 & 3.3667 & 10.3 & 11.5 \\
\hline $13 \ldots \ldots$ & $\ldots \ldots$ & 3.3225 & $\ldots$ & 11.2 \\
\hline $14 \ldots \ldots \ldots \ldots \ldots \ldots \ldots$ & 3.7080 & 3.5429 & 12.4 & 11.1 \\
\hline $15 \ldots \ldots \ldots \ldots \ldots \ldots$ & $\ldots \ldots$ & 3.4250 & $\ldots$ & 11.0 \\
\hline $16 \ldots \ldots \ldots \ldots \ldots \ldots$ & $\ldots \ldots$ & $\ldots \ldots$ & $\ldots$ & $\ldots$ \\
\hline $17 \ldots \ldots \ldots \ldots \ldots \ldots$ & $\ldots \ldots$ & $\ldots \ldots$ & $\ldots$ & $\ldots$ \\
\hline $18 \ldots \ldots \ldots \ldots \ldots \ldots \ldots$ & 3.8500 & $\ldots \ldots$ & 9.3 & $\ldots$ \\
\hline $21 \ldots \ldots \ldots \ldots \ldots \ldots$ & $\ldots \ldots$ & 3.3133 & $\ldots$ & 11.0 \\
\hline $26 \ldots \ldots \ldots \ldots \ldots \ldots$ & 3.2850 & $\ldots \ldots$ & $\ldots$ & $\ldots$ \\
\hline
\end{tabular}

in early embryo size between clutches of varying size. These differences be. tween clutches of varying size are not significant. This can be interpreted as evidence that the eggs in long clutches do not necessarily spend a shorter time in the oviduct.

The information obtained on the relation between time interval and early embryo size stresses the importance of the period of time spent by the egg in the oviduct as a factor influencing the stage of development reached by the embryo at the time of oviposition. Data gathered on eggs occupying first clutch position, in contrast to eggs occupying subsequent clutch positions, have to be submitted to a separate analysis because of the highly significant differences observed in the mean size of the blastoderms and mean number of somites they contain. The lack of a significant correlation between the time interval separating two clutches and early embryo size in eggs occupying first clutch position, makes it impossible to adjust the values on early embryo size for their regression on time interval. Such an adjustment for regression 
of early embryo size on time interval is possible in eggs occupying clutch positions subsequent to the first, because of the comparatively high relation observed between time interval and early embryo size.

\section{Relation Between Hour of Lay and Early Embryo Size}

In Part III, it was demonstrated that eggs laid early in the morning and late in the afternoon did not hatch as well as those laid during the middle part of the day. In view of this demonstration, it was thought of interest to study the possible relation between hour of lay and early embryo size.

TABLE 37

ANALYSIS OF VARIANCE OF EARLY EMBRYO SIZE IN CLUTCHES OF VARIOUS SIZES

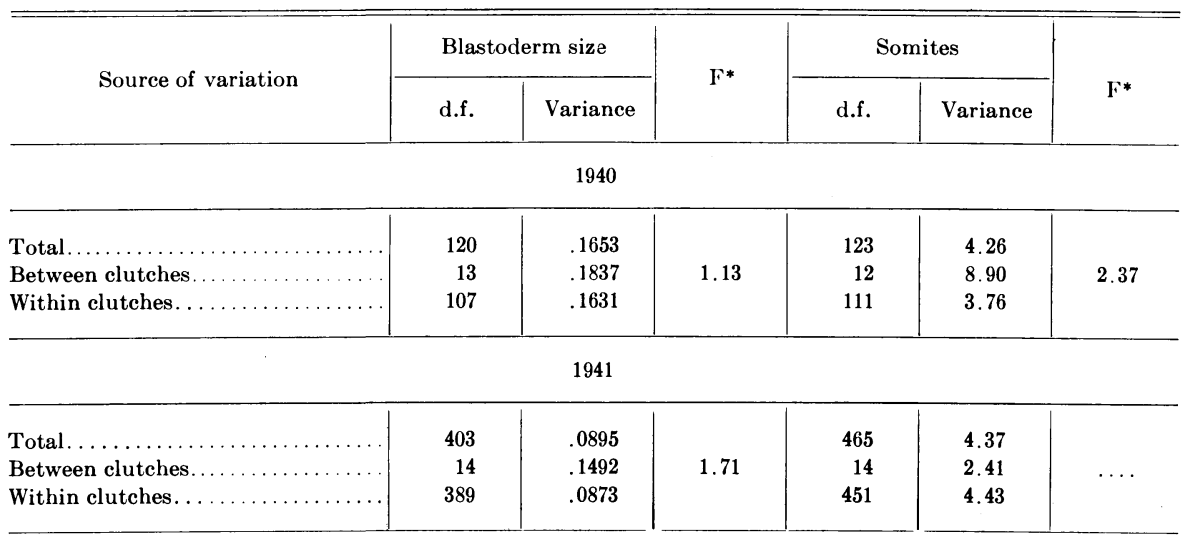

* No significant $\mathrm{F}$ values.

The available data in 1937, 1938, 1940, and 1941, on the relation between hour of lay and blastoderm size are summarized in table 38. Eggs laid early in the morning, particularly those laid at or before 8 o'clock, contained larger blastoderms and exhibited a higher coefficient of variability than eggs laid later in the morning. The trend is for a decrease in blastoderm size at each successive hour of lay in the morning up to noon and again a decrease in eggs laid after 2 o'clock. A test of the homogeneity of the distribution of the eggs classified as to hour of lay and deviation in blastoderm size below or above the mean has given the results presented in table 39. The distribution is definitely heterogeneous; blastoderms vary in size according to the hour of day the eggs are laid. Early morning eggs contain a larger blastoderm than those laid later in the day, and late afternoon eggs contain a smaller blastoderm than those laid earlier in the afternoon.

The data on number of somites present in the embryos after 38 hours of incubation were also classified according to the hour of the day the eggs were laid (table 40). Eggs laid at or before 8 o'clock in the morning and at or after 1 o'clock in the afternoon show a tendency to produce incubated embryos with a larger number of somites than the mean for all eggs. A test of the homogeneity of the distribution of embryos according to number of somites 
TABLE 38

RELATION BETWEEN HOUR OF LAY

AND BLASTODERM SIZE

\begin{tabular}{|c|c|c|c|}
\hline Hour of lay & $\begin{array}{c}\text { Number of } \\
\text { blastoderms }\end{array}$ & Mean size & $\begin{array}{l}\text { Standard } \\
\text { deviation }\end{array}$ \\
\hline 8 o'clock or before $\ldots \ldots \ldots \ldots \ldots \ldots \ldots$ & 199 & 3.7565 & .4317 \\
\hline 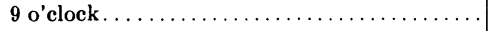 & 105 & 3.7090 & .3339 \\
\hline 10 o'clock. . . . . . . & 323 & 3.6540 & .3160 \\
\hline 11-12 o'clock. ... & 338 & 3.5609 & .2951 \\
\hline 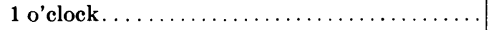 & 278 & 3.5885 & 3380 \\
\hline 2 o'clock. . . . . . . & 100 & 3.6120 & .2936 \\
\hline 3 o'clock. . . . . . . . . & 189 & 3.5728 & .2483 \\
\hline 4 o'clock or after $\ldots \ldots \ldots \ldots \ldots \ldots \ldots \ldots$ & 102 & 3.5618 & .3119 \\
\hline All blastoderms. . . . . . . . . . . . . . . . & 1634 & 3.6219 & .3309 \\
\hline
\end{tabular}

TABLE 39

TEST OF HOMOGENEITY OF THE DISTRIBUTION OF BLASTODERMS AS TO SIZE AND HOUR OF LAY

\begin{tabular}{|c|c|c|c|}
\hline \multicolumn{4}{|c|}{ Blastoderm size below or above mean } \\
\hline Hour of lay & Below & Above & Total \\
\hline 8 o'clock or before $\ldots \ldots \ldots \ldots \ldots \ldots \ldots \ldots \ldots$ & 73 & 126 & 199 \\
\hline 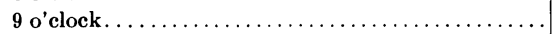 & 40 & 65 & 105 \\
\hline 10 o'clock . . . . . . . . & 156 & 167 & 323 \\
\hline 11-12 o'clock. . . . . . . & 201 & 137 & 338 \\
\hline 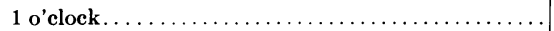 & 153 & 125 & 278 \\
\hline 2 o'clock $\ldots \ldots \ldots \ldots \ldots \ldots \ldots \ldots \ldots \ldots \ldots \ldots \ldots \ldots \ldots \ldots$ & 52 & 48 & 100 \\
\hline 3 o'clock $\ldots \ldots \ldots \ldots \ldots \ldots \ldots \ldots \ldots \ldots \ldots \ldots$ & 108 & 81 & 189 \\
\hline 4 o'clock or after. $\ldots \ldots \ldots \ldots \ldots \ldots \ldots \ldots$ & 60 & 42 & 102 \\
\hline 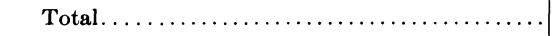 & 843 & 791 & 1634 \\
\hline \multicolumn{4}{|c|}{$\chi^{2}=40.95$} \\
\hline
\end{tabular}

TABLE 40

RELATION BETWEEN HOUR OF LAY AND NUMBER OF SOMITES

\begin{tabular}{|c|c|c|c|}
\hline Hour of lay & $\begin{array}{c}\text { Number of } \\
\text { embryos }\end{array}$ & Mean somites & $\begin{array}{l}\text { Standard } \\
\text { deviation }\end{array}$ \\
\hline 8 o'clock or before $\ldots \ldots \ldots \ldots \ldots \ldots \ldots \ldots$ & 172 & 12.2558 & 2.580 \\
\hline 9 o'clock $\ldots \ldots \ldots \ldots \ldots \ldots \ldots \ldots$ & 43 & 11.3448 & 1.974 \\
\hline 10 o'clock $\ldots \ldots \ldots \ldots \ldots \ldots \ldots \ldots \ldots \ldots \ldots$ & 197 & 11.4264 & 1.768 \\
\hline 11-12 o'clock $\ldots \ldots \ldots \ldots \ldots \ldots \ldots \ldots \ldots \ldots$ & 253 & 11.5375 & 1.789 \\
\hline 1 o'clock $\ldots \ldots \ldots \ldots \ldots \ldots \ldots \ldots \ldots \ldots$ & 205 & 11.8000 & 1.503 \\
\hline 2 o'clock.... & 43 & 11.9302 & 1.737 \\
\hline 3 o'clock............. & 113 & 12.1947 & 1.874 \\
\hline 4 o'clock or after $\ldots \ldots \ldots \ldots \ldots \ldots \ldots \ldots$ & 40 & 11.9000 & 1.464 \\
\hline All embryos........................ & 1066 & 11.7739 & 1.912 \\
\hline
\end{tabular}


TABLE 41

TEST OF HOMOGENEITY OF THE DISTRIBUTION OF

EMBRYOS AS TO NUMBER OF SOMITES AND

WHETHER EGGS WERE LAID BEFORE

OF AFTER 10 O'CLOCK

\begin{tabular}{|c|c|c|c|}
\hline \multirow{2}{*}{ Number of somites } & \multicolumn{2}{|c|}{ Eggs laid } & \multirow{2}{*}{ Total } \\
\hline & $\begin{array}{c}\text { Before } \\
10 \text { o'clock }\end{array}$ & $\begin{array}{c}\text { After } \\
10 \text { o'clock }\end{array}$ & \\
\hline 6 and $7 \ldots$ & 7 & 7 & 14 \\
\hline $8 \ldots \ldots \ldots$ & 19 & 17 & 36 \\
\hline $9 \ldots \ldots \ldots$ & 45 & 42 & 87 \\
\hline $10 \ldots \ldots \ldots \ldots \ldots \ldots \ldots \ldots \ldots \ldots \ldots \ldots \ldots$ & 35 & 76 & 111 \\
\hline $11 \ldots \ldots \ldots \ldots \ldots \ldots \ldots \ldots \ldots \ldots \ldots \ldots \ldots$ & 61 & 116 & 177 \\
\hline 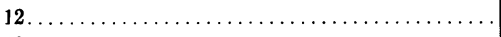 & 82 & 161 & 243 \\
\hline 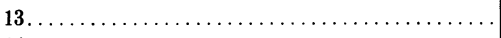 & 98 & 143 & 241 \\
\hline 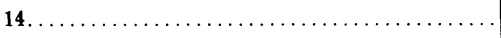 & 50 & 70 & 120 \\
\hline 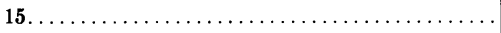 & 6 & 16 & 22 \\
\hline 16 and over $\ldots \ldots \ldots \ldots \ldots \ldots \ldots \ldots \ldots \ldots \ldots \ldots$ & 9 & 6 & 15 \\
\hline Total......................... & 412 & 654 & 1066 \\
\hline \multicolumn{4}{|c|}{$x^{2}=21.17 \quad \mathrm{P}=.01-.02$} \\
\hline
\end{tabular}

TABLE 42

TEST OF HOMOGENEITY OF THE DISTRIBUTION OF MORNING EGGS ACCORDING TO NUMBER OF SOMITES AND TIME OF LAY

\begin{tabular}{|c|c|c|c|}
\hline \multirow[b]{2}{*}{ Number of somites } & \multicolumn{2}{|c|}{ Eggs laid } & \multirow[b]{2}{*}{ Total } \\
\hline & $\begin{array}{l}\text { Before } \\
8 \text { o'clock }\end{array}$ & $\begin{array}{l}\text { Between } \\
8 \text { o'clock } \\
\text { and noon }\end{array}$ & \\
\hline 8 or less $\ldots \ldots \ldots \ldots \ldots \ldots \ldots$ & 8 & 32 & 40 \\
\hline $9 \ldots \ldots \ldots$ & 20 & 42 & 62 \\
\hline $10 \ldots \ldots \ldots \ldots$ & 9 & 62 & 71 \\
\hline $11 \ldots \ldots \ldots \ldots \ldots \ldots \ldots \ldots \ldots \ldots \ldots \ldots$ & 16 & 96 & 112 \\
\hline $12 \ldots \ldots \ldots \ldots \ldots \ldots \ldots \ldots \ldots \ldots \ldots \ldots \ldots \ldots$ & 32 & 103 & 135 \\
\hline $13 \ldots \ldots \ldots \ldots \ldots \ldots \ldots \ldots \ldots \ldots \ldots \ldots \ldots$ & 49 & 108 & 157 \\
\hline $14 \ldots \ldots \ldots \ldots \ldots \ldots \ldots \ldots \ldots \ldots \ldots \ldots \ldots, \ldots$ & 25 & 39 & 64 \\
\hline $15 \ldots \ldots \ldots \ldots \ldots \ldots \ldots \ldots \ldots \ldots \ldots \ldots \ldots$ & 5 & 6 & 11 \\
\hline 16 and over $\ldots \ldots \ldots \ldots \ldots \ldots \ldots \ldots \ldots \ldots$ & 8 & 5 & 13 \\
\hline Total $\ldots \ldots \ldots \ldots \ldots \ldots \ldots \ldots \ldots \ldots \ldots \ldots \ldots \ldots$ & 172 & 493 & 665 \\
\hline \multicolumn{4}{|c|}{$\chi^{2}=35.60$} \\
\hline
\end{tabular}

and whether the eggs were laid before or after 10 o'clock gave the results presented in table 41. The distribution is heterogeneous, and the number of somites present in the embryos after 38 hours of incubation varies according to the time of the day the eggs are laid. Additional tests of the homogeneity of the distribution of embryos according to number of somites and time of lay were made for morning and afternoon eggs separately, tables 42 and 43 . 
Eggs laid in the morning at or before 8 o'clock contain embryos with a larger number of somites than those laid after 8 o'clock and before noon. The distribution is heterogeneous. A large proportion (80\%) of the eggs laid at or before 8 o'clock in the morning are the first of a clutch and have presumably spent a longer period of time in the oviduct.

The eggs laid between 2 and 4 o'clock show a tendency to contain a larger number of somites than the eggs laid between noon and 2 o'clock. The test has revealed, however, that the two distributions are not heterogene-

TABLE 43

TEST OF HOMOGENEITY OF THE DISTRIBUTION OF

AFTERNOON EGGS ACCORDING TO NUMBER

OF SOMITES AND TIME OF LAY

\begin{tabular}{|c|c|c|c|}
\hline \multirow[b]{2}{*}{ Number of somites } & \multicolumn{2}{|c|}{ Eggs laid } & \multirow[b]{2}{*}{ Total } \\
\hline & $\begin{array}{l}\text { Between } \\
\text { noon and } \\
2 \text { o'clock }\end{array}$ & $\begin{array}{l}\text { Between } \\
2 \text { and } \\
4 \text { o'clock }\end{array}$ & \\
\hline 8 or less. . & $\mathbf{5}$ & 5 & 10 \\
\hline $9 \ldots \ldots \ldots$ & 16 & 9 & 25 \\
\hline $10 \ldots \ldots \ldots$ & 27 & 13 & 40 \\
\hline $11 \ldots \ldots \ldots \ldots \ldots$ & 47 & 18 & 65 \\
\hline 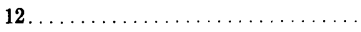 & 67 & 41 & 108 \\
\hline $13 \ldots \ldots$ & 53 & 31 & 84 \\
\hline $14 \ldots \ldots \ldots \ldots \ldots \ldots \ldots \ldots \ldots \ldots$ & 28 & 28 & 56 \\
\hline 15 and over $\ldots \ldots \ldots \ldots \ldots \ldots$ & 5 & 8 & 13 \\
\hline Total. & 248 & 153 & 401 \\
\hline
\end{tabular}

ous; eggs laid between noon and 2 o'clock and between 2 and 4 o'clock contain embryos which did not differ significantly in number of somites after 38 hours of incubation.

In view of the greater mean number of somites observed in eggs occupying the first clutch position as compared to eggs in subsequent clutch positions, a separate analysis of the relation between hour of lay and number of somites was made in the two groups of eggs, table 44. Tests of homogeneity of the distribution of embryos according to number of somites, clutch position and whether the eggs were laid before or after 11 o'clock in the morning have given the results presented in table 45 .

There is no relation between number of somites and hour of lay in eggs occupying the first position in a clutch, but the relation is statistically significant in eggs occupying subsequent clutch positions. In the latter, there is a larger mean number of somites when the egg is laid later in the day.

Further tests of homogeneity of the distribution of embryos according to number of somites and hour of lay were made for eggs occupying a clutch position subsequent to the first, table 46 .

The two distributions are heterogeneous. Eggs in clutch positions subse-

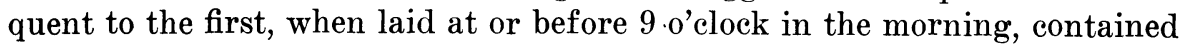


TABLE 44

RELATION BETWEEN HOUR OF LAY AND NUMBER OF SOMITES - IN EGGS ACCORDING TO CLUTCH POSITION

\begin{tabular}{|c|c|c|c|c|c|c|}
\hline \multirow{2}{*}{ Hour of lay } & \multicolumn{3}{|c|}{ Eggs in first clutch position } & \multicolumn{3}{|c|}{ Eggs in subsequent clutch positions } \\
\hline & $\begin{array}{c}\text { Number of } \\
\text { embryos }\end{array}$ & $\begin{array}{l}\text { Mean } \\
\text { somites }\end{array}$ & $\begin{array}{l}\text { Standard } \\
\text { deviation }\end{array}$ & $\begin{array}{l}\text { Number of } \\
\text { embryos }\end{array}$ & $\begin{array}{l}\text { Mean } \\
\text { somites }\end{array}$ & $\begin{array}{l}\text { Standard } \\
\text { deviation }\end{array}$ \\
\hline 8 o'clock or before. & 137 & 12.88 & 2.401 & 35 & 9.80 & 1.659 \\
\hline 11-12 o'clock. . . . . . . . . & 65 & 12.68 & 1.954 & 191 & 11.17 & 1.558 \\
\hline 1 o'clock . . . . . . . . . . & 19 & 13.11 & 1.370 & 183 & 11.64 & 1.452 \\
\hline 2 o'clock...... & 3 & 13.67 & .577 & 40 & 11.80 & 1.728 \\
\hline 3 o'clock. . . . . . . . . . . & 1 & 12.00 & $\ldots \ldots$ & 112 & 12.20 & 1.884 \\
\hline 4 o'clock or after........... & 1 & 10.00 & $\cdots$ & 39 & 11.95 & 1.451 \\
\hline
\end{tabular}

TABLE 45

TESTS OF HOMOGENEITY OF THE DISTRIBUTION OF EMBRYOS BY NUMBER OF SOMITES, ACCORDING TO TIME OF LAY AND CLUTCH POSITION

\begin{tabular}{|c|c|c|c|}
\hline \multirow{2}{*}{ Number of somites } & \multicolumn{2}{|c|}{ Eggs laid } & \multirow{2}{*}{ Total } \\
\hline & $\begin{array}{c}\text { Before } \\
11 \text { o'clock }\end{array}$ & $\begin{array}{c}\text { After } \\
11 \text { o'clock }\end{array}$ & \\
\hline \multicolumn{4}{|l|}{ Eggs in first clutch position } \\
\hline 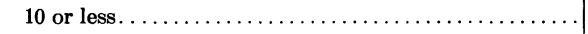 & 28 & 10 & 38 \\
\hline 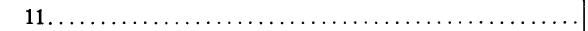 & 25 & $\mathbf{5}$ & 30 \\
\hline $12 \ldots \ldots \ldots \ldots \ldots \ldots \ldots \ldots \ldots \ldots \ldots \ldots \ldots \ldots$ & 49 & 20 & 69 \\
\hline 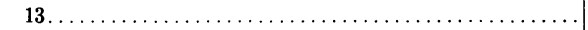 & 72 & 25 & 97 \\
\hline 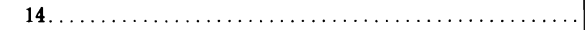 & 46 & 17 & 63 \\
\hline 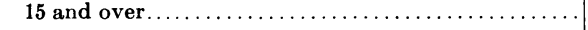 & 15 & 12 & 27 \\
\hline \multirow[t]{2}{*}{ Total.. } & 235 & 89 & 324 \\
\hline & \multicolumn{2}{|c|}{$\chi^{2}=5.92$} & \\
\hline \multicolumn{4}{|l|}{ Eggs in subsequent clutch positions } \\
\hline 7 or less. . . . . . . . . . . . . & 5 & 6 & 11 \\
\hline $8 \ldots \ldots \ldots \ldots \ldots \ldots \ldots \ldots$ & 15 & 16 & 31 \\
\hline $9 \ldots \ldots \ldots \ldots \ldots \ldots \ldots$ & 33 & 40 & 73 \\
\hline $10 \ldots \ldots \ldots$ & 25 & 70 & 95 \\
\hline 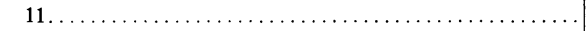 & 36 & 111 & 147 \\
\hline $12 \ldots \ldots \ldots \ldots \ldots \ldots$ & 33 & 141 & 174 \\
\hline 13 and over $\ldots \ldots \ldots \ldots \ldots \ldots \ldots \ldots \ldots \ldots \ldots \ldots$ & 30 & 181 & 211 \\
\hline \multirow[t]{2}{*}{ Total. } & 177 & 565 & 742 \\
\hline & \multicolumn{2}{|c|}{$\chi^{2}=44.84$} & \\
\hline
\end{tabular}


embryos with a smaller number of somites than eggs laid between 9 o'clock and noon. The early morning eggs, in clutch positions subsequent to the first, presumably belong to long clutches in which the time interval is shorter and more regular than in the late morning eggs. The same deductions apply to the early afternoon eggs which contain embryos with a smaller number of somites than those laid later in the afternoon. The eggs laid later in the afternoon are presumably last eggs in a clutch or belong to two-egg clutches which, as shown previously, have a longer time interval expressed in a larger number of somites.

TABLE 46

TEST OF HOMOGENEITY OF THE DISTRIBUTION OF EMBRYOS ACCORDING TO NUMBER OF SOMITES, HOUR OF LAY, AND

WHETHER LAID IN THE MORNING OR IN THE

AFTERNOON, IN EGGS OCCUPYING CLUTCH POSITIONS SUBSEQUENT TO THE FIRST

\begin{tabular}{|c|c|c|c|c|c|c|}
\hline \multirow{2}{*}{ Number of somites } & \multicolumn{2}{|c|}{ Morning eggs } & \multirow{2}{*}{ Total } & \multicolumn{2}{|c|}{ Afternoon eggs } & \multirow{2}{*}{ Total } \\
\hline & $\begin{array}{c}\text { Before } \\
9 \text { o'clock }\end{array}$ & $\begin{array}{c}\text { After } \\
9 \text { o'clock }\end{array}$ & & $\begin{array}{c}\text { Before } \\
2 \text { o'clock }\end{array}$ & $\begin{array}{c}\text { After } \\
2 \text { o'clock }^{\prime}\end{array}$ & \\
\hline 8 or less. . & 9 & 23 & 32 & 5 & 5 & 10 \\
\hline $9 \ldots \ldots \ldots$ & 15 & 33 & 48 & 16 & 9 & 25 \\
\hline $10 \ldots$ & 8 & 48 & 56 & 27 & 12 & 39 \\
\hline $11 \ldots$ & 8 & 76 & 84 & 45 & 18 & 63 \\
\hline $12 \ldots$ & 8 & 65 & 73 & 61 & 40 & 101 \\
\hline $13 \ldots \ldots \ldots \ldots$ & 5 & 70 & 75 & 46 & 31 & 77 \\
\hline 14 and over.. & $\ldots$ & $\ldots$ & $\ldots$ & 23 & 36 & 59 \\
\hline \multirow[t]{2}{*}{ Total.... } & 53 & 315 & 368 & 223 & 151 & 374 \\
\hline & \multicolumn{2}{|c|}{$\chi^{2}=21.89$} & & \multicolumn{2}{|c|}{$\chi^{2}=16.19$} & \\
\hline
\end{tabular}

\section{Relation Between Clutch Position and Hour of Lay}

Both clutch position and hour of lay have been demonstrated to be factors influencing embryo size. The study of the relation between these two factors has given the results presented in table 47 .

A test of the homogeneity of the distribution of eggs in first and subsequent clutch positions according to hour of lay has given a $\chi^{2}$ value of 253.63 with a probability less than .001. Eggs occupying the first clutch position as a rule are laid earlier in the day than eggs occupying subsequent clutch positions.

\section{Relation Between Hour of Lay and Time Interval}

Both time interval and hour of lay have been demonstrated to be factors influencing embryo size and further the two factors are related as shown in table 48. There is an apparent increase in length of time interval with later hours of lay for eggs in both first and subsequent clutch positions, and both distributions are heterogeneous (table 49). 
TABLE 47

RELATION BETWEEN HOUR OF LAY AND CLUTCH POSITION

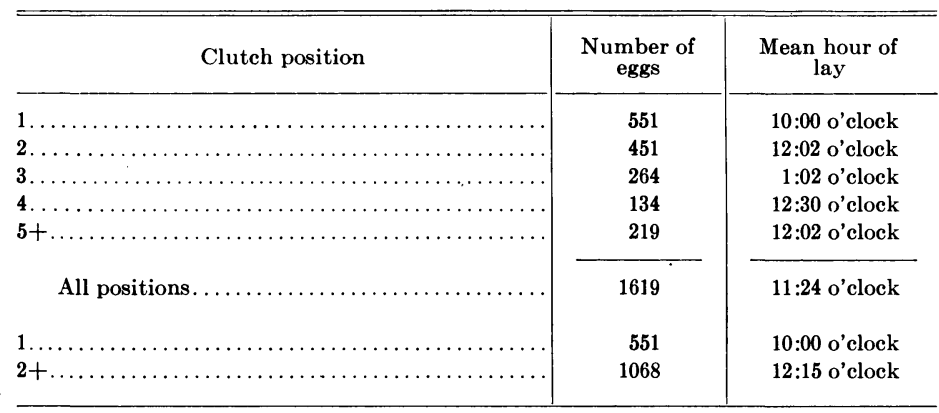

TABLE 48

RELATION BETWEEN HOUR OF LAY AND TIME INTERVAL

\begin{tabular}{|c|c|c|c|}
\hline $\begin{array}{l}\text { Clutch } \\
\text { position }\end{array}$ & Hour of lay & $\begin{array}{l}\text { Number } \\
\text { of eggs }\end{array}$ & $\begin{array}{l}\text { Mean time } \\
\text { interval }\end{array}$ \\
\hline First & 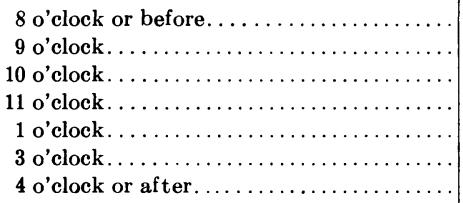 & $\begin{array}{r}121 \\
12 \\
65 \\
45 \\
12 \\
8 \\
2\end{array}$ & $\begin{array}{l}41: 50 \text { hrs. } \\
43: 18 \text { hrs. } \\
43: 36 \text { hrs. } \\
45: 00 \text { hrs. } \\
47: 48 \text { hrs. } \\
50: 54 \text { hrs. } \\
52: 00 \text { hrs. }\end{array}$ \\
\hline & $\begin{array}{c}\text { Total } \ldots \ldots \ldots \ldots \ldots \ldots \ldots \ldots \ldots \ldots \ldots \\
\text { A verage } \ldots \ldots \ldots \ldots \ldots \ldots \ldots\end{array}$ & $\begin{array}{c}265 \\
\cdots \cdots\end{array}$ & $43: 48$ hrs. \\
\hline $\begin{array}{l}\text { Subsequent } \\
\text { to first }\end{array}$ & 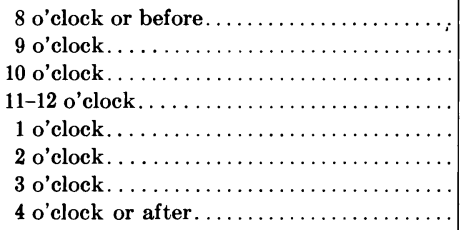 & $\begin{array}{r}39 \\
16 \\
127 \\
147 \\
148 \\
29 \\
133 \\
38\end{array}$ & $\begin{array}{l}23: 24 \text { hrs. } \\
24: 18 \text { hrs. } \\
24: 42 \text { hrs. } \\
25: 16 \text { hrs. } \\
26: 12 \text { hrs. } \\
27: 00 \text { hrs. } \\
27: 24 \text { hrs. } \\
27: 24 \text { hrs. }\end{array}$ \\
\hline & 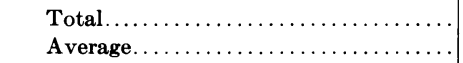 & $\begin{array}{c}677 \\
\ldots \ldots\end{array}$ & $\begin{array}{c}\ldots \ldots \ldots \ldots \\
25: 54 \mathrm{hrs} .\end{array}$ \\
\hline
\end{tabular}

Eggs laid later in the day have a longer time interval regardless of whether they occupy the first position or a subsequent one in a clutch. There is, however, a confounding effect of rate of lay on the relation between time interval and hour of lay. Eggs in short clutches are laid later in the day along with last eggs in longer clutches, and since both those types of eggs have been shown to have a longer time interval, the result is an apparent increase in length of time interval with later hours of lay. 


\section{Individuality of the Bird as It Influences Early Embryo Size}

In the preceding analyses it has been demonstrated that clutch position, time interval between eggs, and hour of lay influence the maximum diameter of the blastoderm in unincubated eggs and also the number of somites present in the embryos after 38 hours of incubation. It was further pointed out that there are interrelations between clutch position, time interval between eggs, and hour of lay, and that these factors reflect variations in. length of time

TABLE 49

TESTS OF HOMOGENEITY OF THE DISTRIBUTION OF EGGS LAID

BEFORE AND AFTER 10 O'CLOCK IN THE MORNING

ACCORDING TO LENGTH OF TIME INTERVAL

\begin{tabular}{|c|c|c|c|c|}
\hline \multirow{2}{*}{$\begin{array}{l}\text { Clutch } \\
\text { position }\end{array}$} & \multirow{2}{*}{ Time interval } & \multicolumn{2}{|c|}{ Eggs laid } & \multirow[b]{2}{*}{ Total } \\
\hline & & $\begin{array}{c}8-10 \\
\text { o'clock }\end{array}$ & $\begin{array}{l}\text { After } 10 \\
\text { o'clock }\end{array}$ & \\
\hline \multirow[t]{2}{*}{ First } & 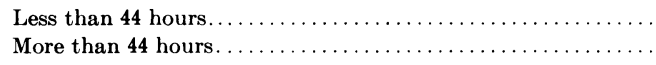 & $\begin{array}{r}169 \\
29\end{array}$ & $\begin{array}{l}23 \\
44\end{array}$ & $\begin{array}{r}192 \\
73\end{array}$ \\
\hline & 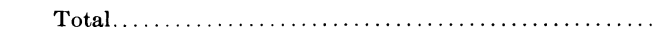 & 198 & 67 & 265 \\
\hline & & \multicolumn{2}{|c|}{$\chi^{2}=62.76$} & .01 \\
\hline \multirow[t]{2}{*}{$\begin{array}{l}\text { Subsequent } \\
\text { to first }\end{array}$} & 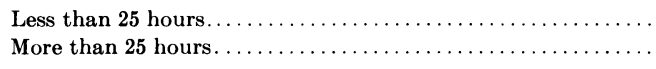 & $\begin{array}{l}203 \\
116\end{array}$ & $\begin{array}{r}56 \\
302\end{array}$ & $\begin{array}{l}259 \\
418\end{array}$ \\
\hline & Total ............ & 319 & 358 & 677 \\
\hline
\end{tabular}

spent by the eggs in the oviduct. As an additional step in the analysis of factors influencing early embryo size, it was thought of interest to study the variations in early embryo size between individual birds.

Variance in Blastoderm Size. An analysis of variance was made of the data gathered on blastoderm size over a period of 11 years and the results are presented in table 50 .

The total variance of blastoderm size for eggs in all clutch positions in each year is reported first. The variances or mean squares range from a low of .0506 in 1930 to a high of .1459 in 1935 .

For eggs in all clutch positions, the variance between means of eggs occupying first and subsequent clutch positions is significantly greater than the variance within first and subsequent clutch positions in all years except 1937. Nine of the $11 \mathrm{~F}$ values are above the $1 \%$ level of significance, one is above the $5 \%$ level and the other is not significant. This result is a confirmation of a fact previously demonstrated in the analysis of the relation between clutch position and blastoderm size.

The data within first clutch position and within subsequent clutch positions were next analyzed for the significance of variation between means of 


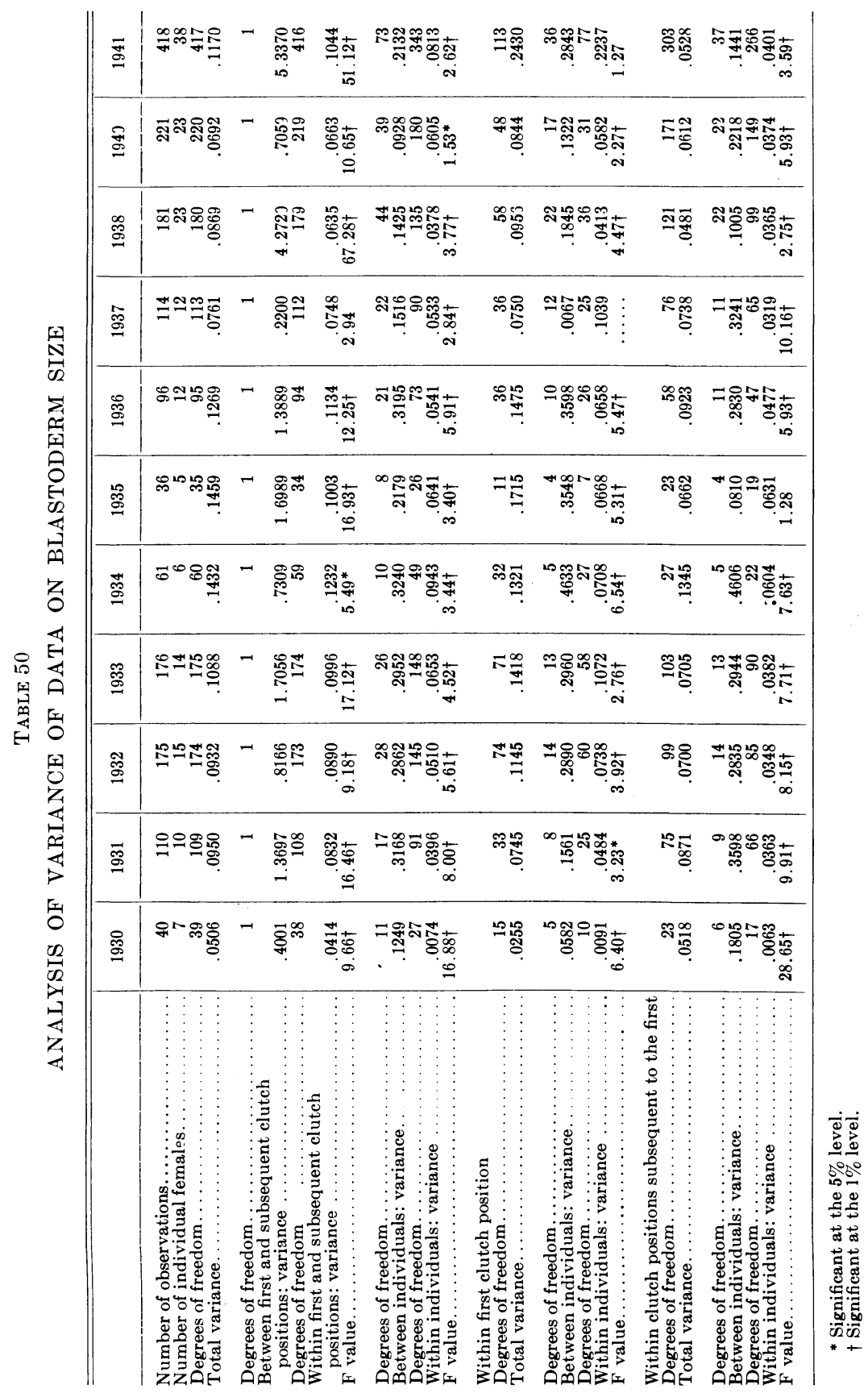


individual birds in blastoderm size. The variance between means of individual birds is significantly greater than the variance of blastoderm size within individuals in each year. Ten of the $\mathrm{F}$ values are above the $1 \%$ level of significance and the other is above the $5 \%$ level of significance. Individual birds thus laid eggs containing blastoderms that differed significantly in size.

A separate analysis of variance was made for the data within first clutch position and for the data within clutch positions subsequent to the first.

Within first clutch position, blastoderm size, as already demonstrated, shows a greater variability than in subsequent positions. Even under that condition, the variance between means of individual birds is significantly greater than the variance within individual birds in nine years out of the 11 . In two years, 1937 and 1941, there is no significant difference between means of individual birds in eggs occupying first clutch position.

In eggs occupying clutch positions subsequent to the first, the variance between means of individual birds is significantly greater than the variance within individuals in ten years out of the 11 . In one year, 1935, there is no significant difference between individual birds probably because the data were gathered on only five birds. In the ten years showing significant differences between individuals, the $\mathrm{F}$ values are all above the $1 \%$ level of significance.

There is very good evidence that differences in the maximum diameter of the blastoderm in unincubated eggs exist between individual dams. These individual differences may be the reflection of characteristic variations in the time spent by the eggs in the oviduct, the result of inherent differences in the rate of embryonic growth, or the expression of slight individual variations in body temperature. In order to determine if the differences in blastoderm size between individuals are accounted for by variations in the length of the time interval between eggs, an analysis of covariance was made of blastoderm size and length of time interval for eggs occupying first clutch position and also for those occupying a subsequent clutch position. Data on length of time interval were available only for 1937, 1938, 1940, and 1941. The results of the analysis of covariance are presented in table 51 for each of the four years and separately for eggs within first and subsequent clutch positions.

In eggs within first clutch position, the correlation coefficients between blastoderm size and time interval in the total population of each year range from +.02 to +.23 . The four correlation coefficients are positive but not significant. The regression coefficients of blastoderm size on time interval range from +.004 to +.026 , and they indicate how small and variable is the change in mean blastoderm size brought about by a variation of one hour in mean time interval. For eggs occupying first clutch position, the correlation coefficients between blastoderm size and time interval within individual birds range from -.26 to +.11 and are all without significance. The regression coefficients of blastoderm size on time interval range from -.021 to +.009 . These coefficients show that the size of the blastoderm within individual birds cannot be predicted to any accurate degree when the time interval of the first egg of a clutch is known. In fact, data on the time interval of the first 
egg of a clutch for a given bird are of no more value in predicting the mean blastoderm size in the eggs of the given birds than is the mean interval of a group of eggs, without reference to individuals, in predicting mean blastoderm size.

Within clutch positions subsequent to the first, the correlation coefficients between time interval and blastoderm size for the sample of each year are all positive and range from .08 to .29 but only the latter coefficient is significant. The regressions of blastoderm size on time interval range from .011 to .036. Within individual birds, and still in cluteh positions subsequent to the first, the correlation coefficients between time interval and blastoderm

TABLE 51

ANALYSIS OF COVARIANCE OF BLASTODERM SIZE AND TIME INTERVAL

\begin{tabular}{|c|c|c|c|c|c|c|c|}
\hline \multirow{2}{*}{ Clutch position } & \multirow{2}{*}{ Year } & \multicolumn{3}{|c|}{ Total } & \multicolumn{3}{|c|}{ Within individual birds } \\
\hline & & d.f. & $\begin{array}{l}\text { Regression } \\
\text { coeff. }\end{array}$ & $\begin{array}{c}\text { Correlation } \\
\text { coeff. }\end{array}$ & d.f. & $\begin{array}{l}\text { Regression } \\
\text { coeff. }\end{array}$ & $\begin{array}{l}\text { Correlation } \\
\text { coeff. }\end{array}$ \\
\hline \multirow[t]{4}{*}{ Eggs in first clutch position........ } & 1937 & 37 & .0260 & .230 & 26 & .0091 & .068 \\
\hline & 1938 & 58 & .0087 & .096 & 36 & .0068 & .110 \\
\hline & 1940 & 48 & .0097 & .104 & 31 & -.0206 & -.259 \\
\hline & 1941 & 113 & .0037 & .021 & 77 & -.0008 & -.004 \\
\hline \multirow[t]{4}{*}{ Eggs in subsequent positions..... } & 1937 & 76 & .0355 & .185 & 64 & .0290 & $.241^{*}$ \\
\hline & 1938 & 121 & .0135 & .113 & 99 & .0268 & .192 \\
\hline & 1940 & 171 & .0114 & .082 & 149 & .0251 & $.238 \dagger$ \\
\hline & 1941 & 303 & .0348 & $.287^{*}$ & 266 & .0369 & $.317 \dagger$ \\
\hline Pooled regression and correlation. & $\ldots$ & $\ldots$ & $\ldots \ldots$ & $\cdots$ & $\ldots$ & .0314 & $.270 \dagger$ \\
\hline
\end{tabular}

* Significant at the $5 \%$ level.

† Significant at the $1 \%$ level.

size within each year range from .19 to .32 and are all positive. Three of the four coefficients of correlation are significant; two at the $1 \%$ level of significance and the other at the 5\% level. The correlation coefficient for the pooled data of the four years is .27 and is significant at the $1 \%$ level of significance. The regression coefficients for each year range from .025 to .037 and for the pooled data the coefficient is .031.

The analysis of covariance has thus revealed that there is a closer correlation between time interval and blastoderm size in eggs occupying clutch positions subsequent to the first than in eggs of the first position. The correlation within individual birds is still higher than that in the sample of eggs in clutch positions subsequent to the first disregarding individuality of dams. This supports evidence previously presented (table 35, page 535), showing that the time interval between eggs in clutch positions subsequent to the first is a better measurement of the actual time the eggs spent in the oviduct than the time interval for eggs occupying first clutch position. The time interval, as a measurement of the actual time spent in the oviduct by the eggs occupying a clutch position subsequent to the first, is also more accurate within individual birds than for a group of birds as a whole. 
The next step consisted of adjusting the data for the regression of blastoderm size on time interval. An analysis of variance of the adjusted values has given the results presented in table 52. This analysis was confined to eggs occupying a clutch position subsequent to the first, since they showed the only significant correlation coefficients between time interval and blastoderm size.

The variance between means of individual birds is significantly greater ( $1 \%$ level of significance) than that within individual birds in each of the four years. The differences between individuals are thus still significant, even after adjustments are made for variations attributed to time interval, and presumably to length of time spent by the eggs in the oviduct. These remain-

TABLE 52

ANALYSIS OF VARIANCE OF DATA ON BLASTODERM SIZE IN EGGS OCCUPYING A CLUTCH POSITION SUBSEQUENT TO THE FIRST, ADJUSTED FOR THE REGRESSION OF BLASTODERM SIZE ON TIME INTERVAL BETWEEN EGGS

\begin{tabular}{c|c|c|c|c|c|c}
\hline \hline Year & $\begin{array}{c}\text { Total } \\
\text { variance }\end{array}$ & $\begin{array}{c}\text { Degrees } \\
\text { of } \\
\text { freedom }\end{array}$ & $\begin{array}{c}\text { Variance } \\
\text { between } \\
\text { individuals }\end{array}$ & $\begin{array}{c}\text { Degrees } \\
\text { of } \\
\text { freedom }\end{array}$ & $\begin{array}{c}\text { Variance } \\
\text { within } \\
\text { individduals }\end{array}$ & $F$ \\
\hline $1937 \ldots \ldots \ldots \ldots \ldots \ldots \ldots \ldots \ldots \ldots \ldots \ldots \ldots$ & .0722 & 11 & .3175 & 25 & .0300 & $10.58 \dagger$ \\
$1938 \ldots \ldots \ldots \ldots \ldots \ldots \ldots \ldots \ldots \ldots \ldots \ldots$ & .0471 & 22 & .1032 & 35 & .0355 & $2.91 \dagger$ \\
$1940 \ldots \ldots \ldots \ldots \ldots \ldots \ldots \ldots \ldots \ldots \ldots \ldots$ & .0611 & 17 & .2349 & 30 & .0353 & $6.65 \dagger$ \\
$1941 \ldots \ldots \ldots \ldots \ldots \ldots \ldots \ldots \ldots \ldots \ldots \ldots$ & .0486 & 36 & .1374 & 76 & .0362 & $3.80 \dagger$ \\
\hline
\end{tabular}

† Significant at the $1 \%$ level.

ing differences between individual birds may still be the result of characteristic variations in the actual time the egg spent in the oviduct, which are not accurately measured by the time interval between eggs. These variations in actual time spent by the egg in the oviduct could be in length of time elapsed between the oviposition of the preceding egg and ovulation. Two other explanations for the individual differences in mean blastoderm size after correction for variations in length of time interval, are that rate of embryonic development and body temperature may vary significantly between birds.

Variance in Embryo Size after 38 Hours of Incubation. The data available on number of somites after 38 hours of incubation, in 1937, 1938, 1940 and 1941, were also analyzed to establish the significance of variations between individuals. An analysis of variance was made for the data of each year, and also separate analyses for eggs in first clutch position and for eggs in clutch positions subsequent to the first. The results of these analyses of variance are presented in table 53. The variance of the total population used in each year is presented first; the range in the latter is from 2.7826 to 3.6229 .

The variance between means of eggs in first and subsequent clutch positions is significantly greater than the variance within first and subsequent clutch positions in all years except 1937. (It is interesting to note that in 1937 there was no significant difference in blastoderm size between the means of eggs in first and of eggs in subsequent clutch positions.) The three significant $\mathrm{F}$ 
values have a $\mathrm{P}$ of .01 or less. The variance between means of individual birds within eggs in first clutch position and eggs in subsequent clutch positions is significantly greater than the variance within individual birds in each of the four years. The $\mathrm{F}$ values are all significant at the $1 \%$ level.

ANALYSIS OF VARIANCE OF DATA ON NUMBER OF SOMITES PRESENT IN THE EMBRYOS AFTER 38 HOURS OF INCUBATION

\begin{tabular}{|c|c|c|c|c|}
\hline & 1937 & 1938 & 1940 & 1941 \\
\hline Number of observations. . & 185 & 230 & 197 & 465 \\
\hline 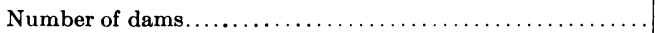 & 12 & 22 & 21 & 35 \\
\hline Degrees of freedom $\ldots \ldots \ldots \ldots \ldots \ldots \ldots \ldots \ldots \ldots \ldots \ldots$ & 184 & 229 & 196 & 464 \\
\hline 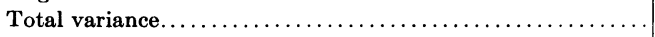 & 3.1821 & 2.7826 & 3.6229 & 3.1614 \\
\hline Degree of freedom $\ldots \ldots \ldots \ldots \ldots \ldots \ldots \ldots \ldots \ldots \ldots \ldots \ldots \ldots$ & 1 & 1 & 1 & 1 \\
\hline Between first and subsequent clutch positions: variance...... & 11.2561 & 67.1220 & 73.9243 & 48.8451 \\
\hline 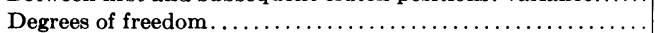 & 183 & 228 & 195 & 463 \\
\hline 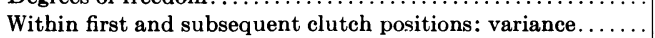 & 3.1380 & 2.5004 & 3.2623 & 3.0663 \\
\hline 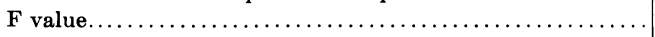 & 3.59 & $26.84 \dagger$ & $22.66 \dagger$ & $15.14 \dagger$ \\
\hline Degrees of freedom. ....................... & 22 & 40 & 37 & 67 \\
\hline Between individuals: variance................ & 13.8348 & 5.6040 & 8.3451 & 6.2953 \\
\hline Degrees of freedom...................... & 161 & 188 & 158 & 396 \\
\hline Within individuals: variance $\ldots \ldots \ldots \ldots \ldots \ldots \ldots \ldots \ldots$ & 1.6764 & 1.8401 & 2.0721 & 2.6909 \\
\hline F value $\ldots \ldots \ldots \ldots \ldots \ldots \ldots \ldots$ & $8.25 \dagger$ & $3.05 \dagger$ & $4.03 \dagger$ & $2.34 \dagger$ \\
\hline \multicolumn{5}{|l|}{ Within first clutch position } \\
\hline Degrees of freedom.......... & 61 & 75 & 38 & 137 \\
\hline Total variance............ & 3.5137 & 2.5689 & 3.3657 & 2.2302 \\
\hline Degrees of freedom $\ldots \ldots \ldots \ldots \ldots \ldots \ldots \ldots \ldots \ldots \ldots$ & 11 & 19 & 17 & 33 \\
\hline Between individuals: variance $\ldots \ldots \ldots \ldots \ldots \ldots \ldots \ldots$ & 13.2881 & 4.2421 & 5.1207 & 3.9216 \\
\hline Degrees of freedom $\ldots \ldots \ldots \ldots \ldots \ldots \ldots \ldots \ldots \ldots \ldots$ & 50 & 56 & 21 & 104 \\
\hline Within individuals: variance $\ldots \ldots \ldots \ldots \ldots \ldots \ldots \ldots$ & 1.3634 & 2.0013 & 1.9450 & 1.6935 \\
\hline F value $\ldots \ldots \ldots \ldots \ldots \ldots \ldots \ldots \ldots$ & $9.75 \dagger$ & $2.12^{*}$ & $2.63^{*}$ & $2.32 \dagger$ \\
\hline \multicolumn{5}{|l|}{ Within subsequent clutch positions } \\
\hline 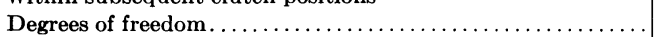 & 122 & 153 & 157 & 326 \\
\hline 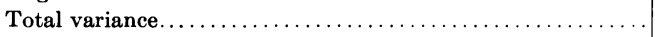 & 2.9502 & 2.4669 & 3.2373 & 3.4176 \\
\hline Degrees of freedom $\ldots \ldots \ldots \ldots \ldots \ldots \ldots \ldots \ldots \ldots \ldots \ldots \ldots$ & 11 & 21 & 20 & 34 \\
\hline Between individuals: variance $\ldots \ldots \ldots \ldots \ldots \ldots \ldots \ldots$ & 14.3810 & 6.8363 & 11.0859 & 7.2535 \\
\hline Degrees of freedom & 111 & 132 & 137 & 292 \\
\hline Within individuals: variance $\ldots \ldots \ldots \ldots \ldots \ldots \ldots$ & 1.8174 & 1.7717 & 2.0916 & 2.9710 \\
\hline 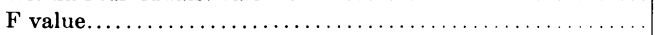 & $7.91 \dagger$ & $3.86 \dagger$ & $5.30 \dagger$ & $2.44 \dagger$ \\
\hline
\end{tabular}

* Significant at the $5 \%$ level.

$\dagger$ Significant at the $1 \%$ level.

A separate analysis of variance of number of somites in eggs occupying the first position in a clutch and in eggs occupying subsequent clutch positions was also made. In eggs occupying the first clutch position, the variance between means of individual birds was significantly greater than the variance within individuals. Two of the four $\mathrm{F}$ values were significant at the $1 \%$ level and the other two were significant at the $5 \%$ level. In eggs occupying a clutch position subsequent to the first, the variance between means of individual 
birds was also significantly greater than the variance within individuals. The four $\mathrm{F}$ values were all significant at the $1 \%$ level.

The results of the analysis of variance of the data on number of somites are in very good agreement with those obtained in the analysis of the data on blastoderm size. They both indicate that significant differences in early embryo size, measured either by maximum blastoderm size in the unincubated egg or number of somites after 38 hours of incubation, exist between individual birds.

The individual differences in number of somites, like those in blastoderm size, may be the result of characteristic variations in the length of time the

TABLE 54

ANALYSIS OF COVARIANCE OF NUMBER OF SOMITES AND TIME INTERVAL

\begin{tabular}{|c|c|c|c|c|c|c|c|}
\hline \multirow{2}{*}{ Clutch position } & \multirow{2}{*}{ Year } & \multicolumn{3}{|c|}{ Total } & \multicolumn{3}{|c|}{ Within individual birds } \\
\hline & & d.f. & $\begin{array}{l}\text { Regression } \\
\text { coefficient }\end{array}$ & $\begin{array}{c}\text { Correlation } \\
\text { coefficient }\end{array}$ & d.f. & $\begin{array}{l}\text { Regression } \\
\text { coefficient }\end{array}$ & $\begin{array}{l}\text { Correlation } \\
\text { coefficient }\end{array}$ \\
\hline \multirow{4}{*}{$\begin{array}{l}\text { Eggs in first clutch } \\
\text { position }\end{array}$} & 1937 & 61 & .078 & .08 & 50 & .236 & $.38 \dagger$ \\
\hline & 1938 & 75 & .025 & .04 & 56 & .084 & .10 \\
\hline & 1940 & 38 & .022 & .03 & 21 & .225 & .35 \\
\hline & 1941 & 137 & .017 & .02 & 104 & .033 & .04 \\
\hline \multirow{4}{*}{$\begin{array}{l}\text { Eggs in subsequent } \\
\text { positions }\end{array}$} & 1937 & 122 & .297 & $.44 \dagger$ & 111 & .282 & $.52 \dagger$ \\
\hline & 1938 & 153 & .194 & $.28 \dagger$ & 132 & .105 & .11 \\
\hline & 1940 & 157 & .235 & $.23 \dagger$ & 137 & .431 & $.43 \dagger$ \\
\hline & 1941 & 326 & .337 & $.32 \dagger$ & 292 & .260 & $.24 \dagger$ \\
\hline
\end{tabular}

† Significant at the $1 \%$ level.

eggs spent in the oviduct and they may also be the effect of genetic or other differences in the rate of embryonic growth. An analysis of the covariance of number of somites and length of time interval was made to throw more light on the problem. The data gathered on eggs occupying first clutch position and on eggs occupying a clutch position subsequent to the first were analyzed separately. The results of these analyses of covariance are presented in table 54 .

In eggs occupying the first position in a clutch, the correlation coefficients between number of somites and time interval for the total sample of each year range from .02 to .08 and are not significant. The regression coefficients of number of somites on time interval are all low and range from .017 to .078 . Within individual birds and still within eggs in first clutch position, the correlation coefficients between number of somites and time interval range from .04 to .38 and only the latter coefficient is significant. The regression coefficients range from .033 to .236 . Contrary to what was observed in the analysis of blastoderm size, the correlation between time interval and number of somites is higher within individuals than when individuality is disregarded, and the regression coefficients also indicate some relation between the two variables.

In eggs occupying a clutch position subsequent to the first, the correlation coefficients between number of somites and time interval range from .23 to .44 . 
They are all significant at the $1 \%$ level. The regression coefficients of number of somites on time interval range from .194 to .337 and indicate an appreciable influence of time interval on number of somites. Within individual birds and still within eggs occupying a clutch position subsequent to the first, the correlation coefficients between time interval and number of somites range from .11 to .53 ; three of the four coefficients are significant at the $1 \%$ level of significance and the other is not significant. The regression coefficients of number of somites on time interval range from .105 to .431 .

The analysis of covariance of number of somites and time interval has revealed a closer relation between the two variables in eggs occupying a

TABLE 55

ANALYSIS OF VARIANCE OF DATA ON NUMBER OF SOMITES IN EGGS OCCUPYING A OLUTCH POSITION SUBSEQUENT TO THE FIRST, ADJUSTED FOR THE REGRESSION OF NUMBER OF SOMITES ON TIME INTERVAL

\begin{tabular}{c|c|c|c|c|c|c}
\hline \hline Year & $\begin{array}{c}\text { Total } \\
\text { variance }\end{array}$ & $\begin{array}{c}\text { Degrees } \\
\text { of } \\
\text { freedom }\end{array}$ & $\begin{array}{c}\text { Variance } \\
\text { between } \\
\text { individuals }\end{array}$ & $\begin{array}{c}\text { Degrees } \\
\text { of } \\
\text { freedom }\end{array}$ & $\begin{array}{c}\text { Variance } \\
\text { within } \\
\text { individuals }\end{array}$ & $F$ \\
\hline $1937 \ldots \ldots \ldots \ldots \ldots \ldots \ldots \ldots \ldots \ldots \ldots \ldots$ & 2.3926 & 11 & 13.2699 & 110 & 1.3266 & $10.00 \dagger$ \\
$1938 \ldots \ldots \ldots \ldots \ldots \ldots \ldots \ldots \ldots \ldots \ldots$ & 2.2759 & 21 & 5.5777 & 131 & 1.7640 & $3.16 \dagger$ \\
$1940 \ldots \ldots \ldots \ldots \ldots \ldots \ldots \ldots \ldots \ldots \ldots \ldots$ & 3.0890 & 20 & 12.4109 & 136 & 1.7181 & $7.22 \dagger$ \\
$1941 \ldots \ldots \ldots \ldots \ldots \ldots \ldots \ldots \ldots \ldots \ldots$ & 3.0754 & 34 & 5.4135 & 291 & 2.8031 & $1.93 \dagger$ \\
\hline
\end{tabular}

† Significant at the $1 \%$ level.

clutch position subsequent to the first than in eggs in first clutch position. The same result was obtained in the analysis of blastoderm size. A closer relation between number of somites and time interval was also observed within the eggs of individual birds than in the sample disregarding individuals. This latter relation was much more marked in eggs occupying a clutch position subsequent to the first although a slight relation was also present in eggs in first clutch position.

The data on number of somites were adjusted for the regression of number of somites on time interval and then submitted to an analysis of variance. Only the data available on eggs occupying a clutch position subsequent to the first were analyzed in view of the higher relation observed in them between the two variables. The results of this analysis of variance are presented in table 55 .

The differences between individuals in mean number of somites remain highly significant even after adjusting number of somites for variations in length of time interval between eggs.

Individual Variations in Early Embryo Size Between Years. In the course of their investigations on blastoderm size, Taylor and Gunns (unpublished) gathered data on the same birds in two consecutive years. These data were analyzed to establish if any significant difference in the mean blastoderm size of the same birds was observed between years. Only eggs occupying a clutch position subsequent to the first were used in the analysis. A total of 105 observations made on eight females were available. The results of the analysis of variance are presented in table 56. 
Highly significant differences were observed between individual hens but these birds also produced eggs which contained blastoderms that varied significantly in size in different years. Unfortunately the data on time interval were not available, and it remains to be determined whether the differences between years are accounted for by variations in time interval or by genetic differences such as could be effected by mating to different males in consecutive years. It is important, however, to note that the same hen will not necessarily produce eggs that will contain blastoderms of the same size in different years. For this reason any study of the influence of genetic factors on early

TABLE 56

ANALYSIS OF VARIANCE OF BLASTODERM SIZE BETWEEN YEARS IN THE SAME INDIVIDUALS

AS MEASURED IN EGGS OCCUPYING A CLUTCH POSITION SUBSEQUENT TO THE FIRST

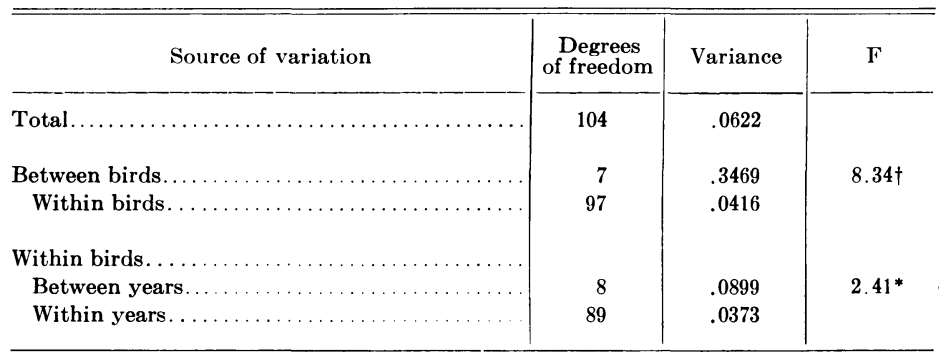

* Significant at the $5 \%$ level.

$\dagger$ Significant at the $1 \%$ level.

embryo size must be made within a period of time when rate of production is uniform in order to make the necessary corrections for variations in time spent by the eggs in the oviduct.

\section{Influence of Systems of Mating on Early Embryo Size}

The preceding analyses have demonstrated that, even after blastoderm size and number of somites are adjusted for their regression on length of time interval between eggs, there are still significant differences between dams. As previously suggested, these may still be the result of characteristic variations in length of time the eggs of an individual hen remain in the oviduct. The latter variations may not be measured accurately by the length of the time interval between eggs, because of fluctuations in the length of time elapsing between the oviposition of the preceding egg and ovulation. The differences in mean blastoderm size and in number of somites between individual hens may also be the result of slight individual variations in body temperature. Finally, the differences between individuals may also be due to genetic differences in the rate of early embryonic growth.

In order to test this last hypothesis of genetic differences in early embryonic growth, the experimental design outlined in the general introduction to these studies was followed. It consisted of mating females of three different origins, within the same year, and in turn with males of the same three origins. 
This resulted in various degrees of inbreeding, in outcrossing, and in crossbreeding. If genetic factors influence rate of early embryonic growth, the experimental design followed should allow their demonstration on blastoderm size and on number of somites.

To reduce the labor involved in the statistical analysis, as well as to profit from the facts observed in the preliminary analysis, only the data gathered on eggs occupying a clutch position subsequent to the first were used since they allowed making the necessary adjustments for regression on time interval.

A summary of the data gathered under the experimental design in 1940 and 1941, classified according to periods, origins of males, origins of females, systems of mating, and in 1941, levels of inbreeding of progeny, is given in table 57. Both blastoderm size and number of somites show apparent variations between periods, between origins of males, between origins of females, and between systems of mating. Of immediate interest are the smaller mean blastoderm size and lower mean number of somites observed in both years under inbreeding as compared to outcrossing and crossbreeding.

The preliminary analyses of variations in both blastoderm size and number of somites have revealed that clutch position, time interval between eggs, and individuality of the dams have to be taken into account in the analysis of data on early embryo size. The first factor was eliminated from the present analysis as only eggs occupying a clutch position subsequent to the first were used. An additional source of variation necessarily taken into account in view of the experimental design followed was that of the possible influence of season or periods within each year. As shown in table 57, periods have apparently influenced early embryo size.

The data on blastoderm size, for 1940 and 1941, were submitted to an analysis of their covariance with time interval and the results are presented in tables 58 and 59 for 1940 and 1941 respectively. The variations in blastoderm size between periods were significant in 1941, but without significance in 1940 . The variations in time interval between periods were highly significant in both 1940 and 1941. The adjustment of the means of blastoderm size for their regression on time interval accounted for the variations observed between periods. The variations in mean blastoderm size observed between periods in 1941 were thus the result of variations in length of time interval between eggs.

The three origins of females used each year differed very significantly in mean blastoderm size within periods. In 1940 there were also significant differences in mean time interval between eggs in the three origins but not in 1941. The values on blastoderm size corrected for their regression on time interval still showed highly significant differences between origins of females. This is in agreement with a previous conclusion that the individuality of the hen affects mean early embryo size, since each origin of females was comprised of related individuals.

Significant differences in mean blastoderm size and time interval were observed between systems of mating within origins of females within periods in both years. The differences in mean blastoderm size between systems of 
TABLE 57

SUMMARY OF DATA ON BLASTODERM SIZE AND NUMBER OF SOMITES

GATHERED ON EGGS OCCUPYING A CLUTCH POSITION SUBSEQUENT

TO THE FIRST, IN 1940 AND 1941, CLASSIFIED ACCORDING TO

PERIODS, ORIGINS OF MALES, ORIGINS OF FEMALES, SYSTEMS OF MATING AND DEGREES OF INBREEDING OF PROGENY

\begin{tabular}{|c|c|c|c|c|c|c|}
\hline \multirow[b]{2}{*}{ Classification } & \multicolumn{3}{|c|}{ Blastoderm size } & \multicolumn{3}{|c|}{ Number of somites } \\
\hline & Number & $\begin{array}{c}\text { Mean } \\
\text { blastoderm } \\
\text { size }\end{array}$ & $\begin{array}{c}\text { Mean } \\
\text { time } \\
\text { interval }\end{array}$ & Number & $\begin{array}{c}\text { Mean } \\
\text { somites }\end{array}$ & $\begin{array}{c}\text { Mean } \\
\text { time } \\
\text { interval }\end{array}$ \\
\hline \multicolumn{7}{|c|}{1940} \\
\hline \multicolumn{7}{|l|}{ Periods } \\
\hline $1 \ldots \ldots$ & 67 & 3.6148 & 25:55 hrs. & 56 & 10.54 & $26: 00 \mathrm{hrs}$. \\
\hline $2 \ldots$ & 72 & 3.5779 & $24: 34$ hrs. & 74 & 10.24 & 25:01 hrs. \\
\hline $3 \ldots$ & 33 & 3.5297 & $24: 49$ hrs. & 28 & 10.79 & $25: 08 \mathrm{hrs}$. \\
\hline \multicolumn{7}{|l|}{ Origins of males } \\
\hline SE $\ldots \ldots \ldots \ldots$ & 62 & 3.6239 & $24: 52 \mathrm{hrs}$. & 55 & 10.75 & 25:10 hrs. \\
\hline OB... & 50 & 3.5542 & $25: 07 \mathrm{hrs}$. & 46 & 10.28 & $25: 37 \mathrm{hrs}$. \\
\hline $\mathrm{CB} \ldots \ldots \ldots \ldots$ & 60 & 3.5648 & $25: 27 \mathrm{hrs}$. & 57 & 10.28 & $25: 25$ hrs. \\
\hline \multicolumn{7}{|l|}{ Origins of females } \\
\hline SE.......... & 22 & 3.6855 & $26: 38 \mathrm{hrs}$. & 19 & 11.00 & $27: 13 \mathrm{hrs}$. \\
\hline oB............ & 123 & 3.6079 & $24: 33 \mathrm{hrs}$. & 115 & 10.49 & $24: 52 \mathrm{hrs}$. \\
\hline 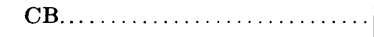 & 27 & 3.3863 & $26: 34 \mathrm{hrs}$. & 24 & 9.79 & $26: 28 \mathrm{hrs}$. \\
\hline \multicolumn{7}{|l|}{ Systems of mating } \\
\hline Inbreeding....... & 46 & 3.4911 & $25: 20 \mathrm{hrs}$ & 40 & 10.05 & $25: 37 \mathrm{hrs}$. \\
\hline Outcrossing....... & 59 & 3.6622 & $24: 45 \mathrm{hrs}$ & 55 & 10.85 & 25:14 hrs. \\
\hline Crossbreeding. ......... & 67 & 3.5764 & $25: 20 \mathrm{hrs}$. & 63 & 10.33 & $25: 22 \mathrm{hrs}$. \\
\hline Data for all embryos... & 172 & 3.5830 & $25: 08 \mathrm{hrs}$ & 158 & 10.44 & $25: 23 \mathrm{hrs}$. \\
\hline \multicolumn{7}{|c|}{1941} \\
\hline \multicolumn{7}{|l|}{ Periods } \\
\hline $1 \ldots$ & 89 & 3.5430 & $26: 50 \mathrm{hrs}$. & 91 & 11.99 & $27: 02 \mathrm{hrs}$. \\
\hline $2 \ldots \ldots$ & 120 & 3.4690 & $25: 39$ hrs. & 130 & 11.62 & $25: 37 \mathrm{hrs}$. \\
\hline $3 \ldots \ldots$ & 95 & 3.4440 & $25: 38$ hrs. & 106 & 11.79 & $25: 12$ hrs. \\
\hline \multicolumn{7}{|l|}{ Origins of males } \\
\hline SEOBs....... & 112 & 3.4553 & $26: 06 \mathrm{hrs}$. & 193 & 12.00 & 25:56 hrs. \\
\hline $\mathrm{OB}^{2} \ldots \ldots \ldots$ & 108 & 3.5242 & 25:53 hrs. & 123 & 11.64 & $25: 42 \mathrm{hrs}$. \\
\hline XB.... & 84 & 3.4665 & $25: 59 \mathrm{hrs}$. & 91 & 11.69 & $26: 04 \mathrm{hrs}$. \\
\hline \multicolumn{7}{|l|}{ Origins of females } \\
\hline SEOBs and SEOBI. & 204 & 3.4669 & 25:49 hrs. & 219 & 11.82 & $25: 44 \mathrm{hrs}$. \\
\hline $\mathrm{OB}^{2} \ldots \ldots \ldots \ldots \ldots$ & 16 & 3.3700 & $26: 23 \mathrm{hrs}$. & 14 & 10.29 & $25: 34$ hrs. \\
\hline $\mathrm{XB} \ldots \ldots \ldots \ldots \ldots \ldots \ldots$ & 84 & 3.5431 & $26: 20$ hrs. & 94 & 11.90 & $26: 16$ hrs. \\
\hline \multicolumn{7}{|l|}{ Systems of mating } \\
\hline lnbreeding $\ldots \ldots \ldots \ldots \ldots$ & 186 & 3.4651 & 26:01 hrs. & 190 & 11.71 & $25: 46 \mathrm{hrs}$. \\
\hline 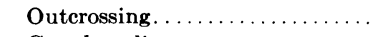 & $\ldots$ & $\ldots \ldots$ & $\ldots \ldots \ldots$ & $\ldots$ & $\ldots$ & $\ldots \ldots \ldots$ \\
\hline Crossbreeding . . . . . . . . . . . & 118 & 3.5108 & $25: 56 \mathrm{hrs}$. & 137 & 11.88 & $26: 03$ hrs. \\
\hline Data for all embryos......... & 304 & 3.4828 & 25:59 hrs. & 327 & 11.78 & $25: 53 \mathrm{hrs}$. \\
\hline \multicolumn{7}{|l|}{ Levels of inbreeding of progeny } \\
\hline $.1250 \ldots \ldots \ldots \ldots \ldots \ldots$ & 80 & 3.4814 & $25: 48$ hrs. & 79 & 11.62 & $25: 35$ hrs. \\
\hline $.16-.2514 \ldots \ldots \ldots \ldots \ldots \ldots \ldots \ldots$ & 74 & 3.4720 & $26: 12$ hrs. & 70 & 11.67 & $25: 40$ hrs. \\
\hline $.30-.3750 \ldots \ldots \ldots \ldots \ldots$ & 32 & 3.4081 & $26: 08 \mathrm{hrs}$. & 41 & 11.95 & $26: 14 \mathrm{hrs}$. \\
\hline
\end{tabular}


mating remained significant after adjustment for regression of blastoderm size on time interval. In both years, inbreeding thus resulted in a lower mean blastoderm size as compared to outbreeding.

In 1941, no significant difference in mean blastoderm size or in time interval was observed between the various levels of inbreeding of the progeny. They remained without significance after adjustment for regression on time interval.

Origins of females, systems of mating or inbreeding and outbreeding, as well as individuality of the females were thus the sources of significant variations in mean blastoderm size before and after adjustments were made for regression of blastoderm size on time interval.

The data on number of somites for 1940 and 1941 were also submitted to an analysis of their covariance with time interval and the results are presented in table 60 and table 61 for 1940 and 1941 respectively. No significant difference in mean number of somites was observed between periods in 1940 or 1941. The differences in mean time interval were, however, highly significant in both 1940 and 1941. The data on number of somites adjusted for regression on time interval still showed no significant difference in mean number of somites between periods.

Significant differences in mean number of somites were observed between origins of females within periods in 1941 but the differences were not significant in 1940. The differences in time interval between origins within periods were highly significant in both years. The adjustment of the values on number of somites for regression on time interval resulted in highly significant differences between origins of females in both years.

The differences in mean number of somites between systems of mating within origins of females within periods were significant in 1940 and not significant in 1941. No significant difference in time interval was observed between systems of mating. Adjustment of the number of somites for its regression on time interval changed the highly significant differences observed in 1940 between systems of mating to the barely significant level (observed $\mathrm{F}$ value being 1.92 as compared to 1.90 at $\mathrm{P} .05$ ), but the differences between systems of mating observed in 1941 remained without significance.

In 1941, the differences in mean number of somites between the levels of inbreeding of the progeny were without significance before and after adjusting the values on number of somites for their regression on time interval.

Highly significant differences in mean number of somites were observed between individuals within systems of mating in both years. Significant differences were also observed in time interval between individuals in 1941 but not in 1940. The values on number of somites adjusted for their regression on time interval resulted in highly significant differences in mean number of somites between individuals in both 1940 and 1941 .

Mean number of somites adjusted for regression on time interval was thus affected primarily by origins of females, individuality of the females, and in 1940 possibly by systems of mating.

These detailed analyses of covariance of blastoderm size and time interval, and number of somites and time interval, gave results that agree completely so far as origins of females and individuality of the females are concerned. 


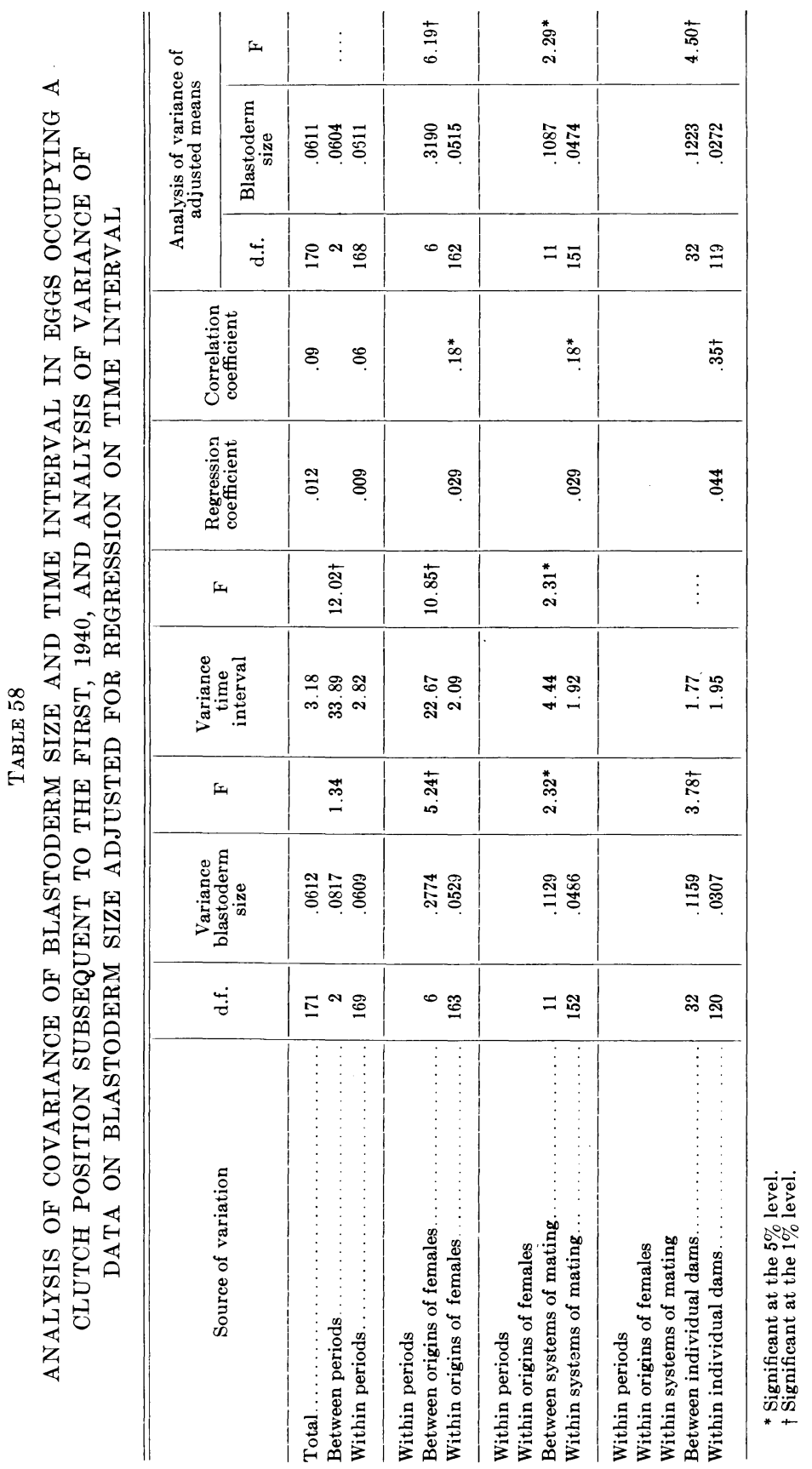




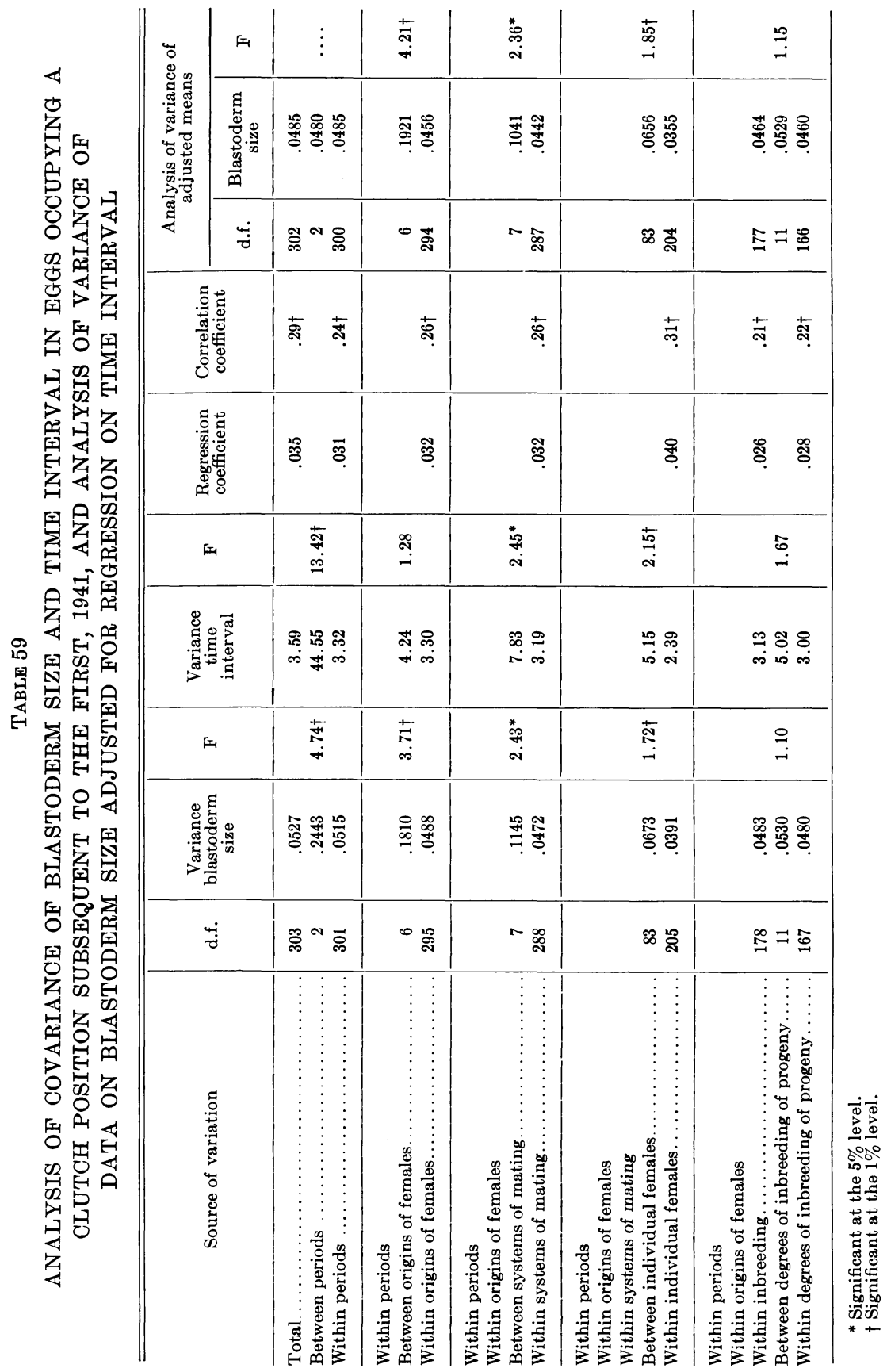




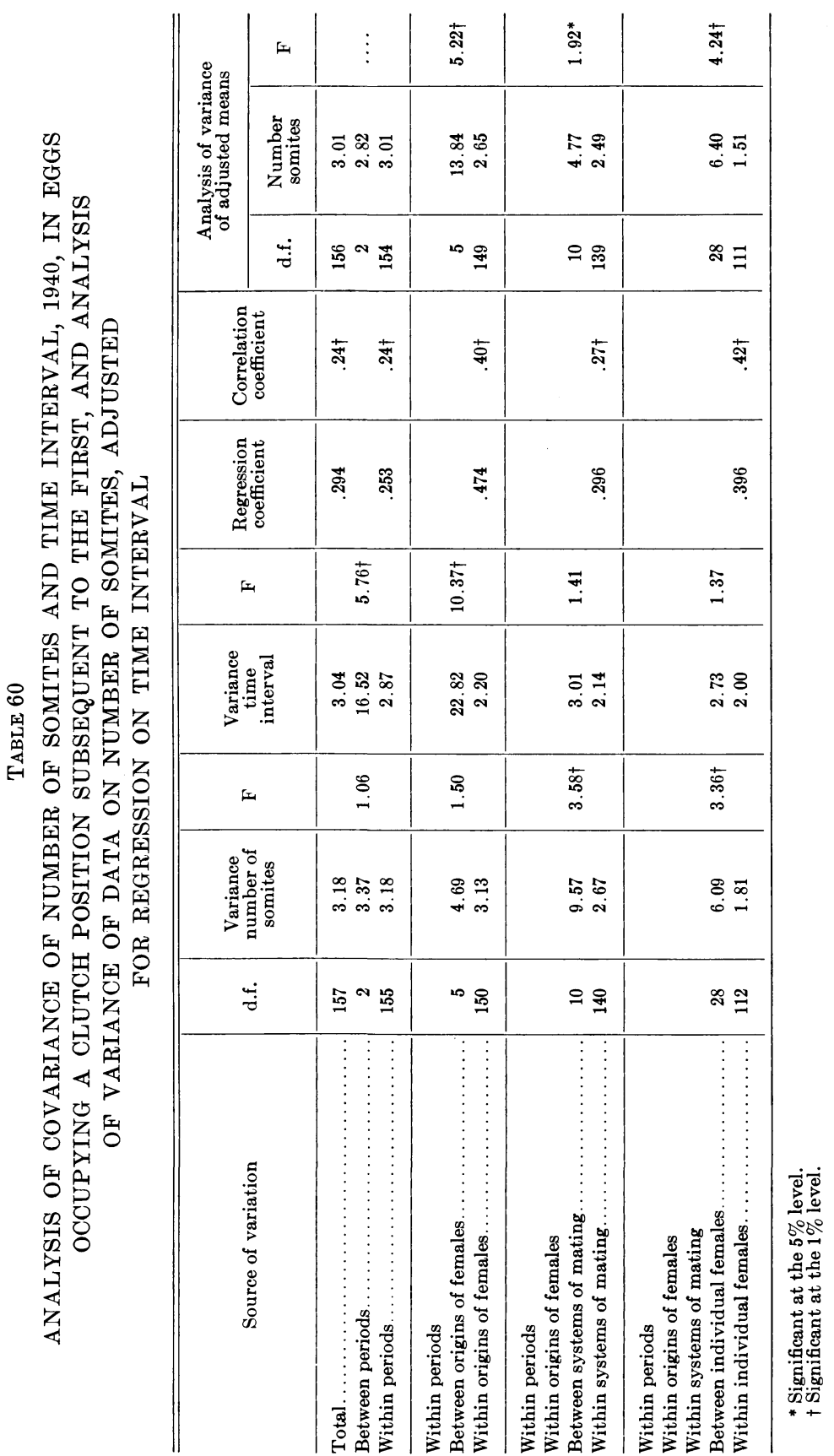




\begin{tabular}{|c|c|c|c|c|c|c|}
\hline \multirow{11}{*}{ 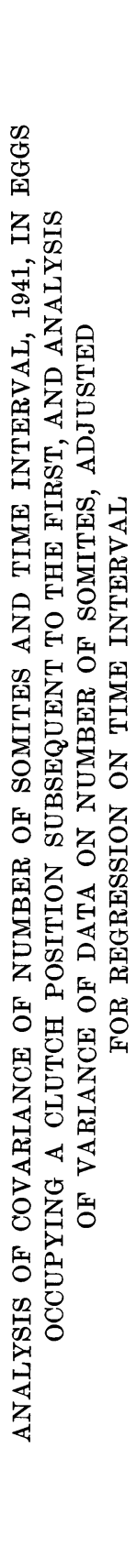 } & \multirow{3}{*}{ 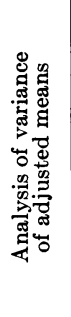 } & $\stackrel{\infty}{-}$ & $\underset{⿱ ㇒}{ \pm}$ & $\vdots$ & 京 & 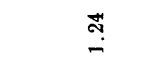 \\
\hline & & 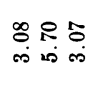 & $\begin{array}{l}\infty \\
\stackrel{\infty}{*}: \\
0 \\
0\end{array}$ & 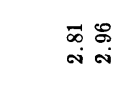 & $\begin{array}{l}\mathcal{S}: 8 \\
\text { is }\end{array}$ & 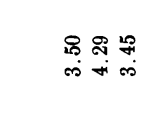 \\
\hline & & జ్లె ๙ స్లొ & $0 \stackrel{-\pi}{m}$ & 용 & స̃ & $\stackrel{\infty}{\infty} \underset{\Xi}{ }$ \\
\hline & 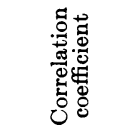 & 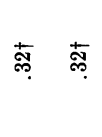 & 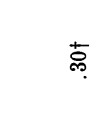 & 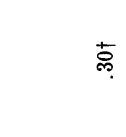 & 旁 & 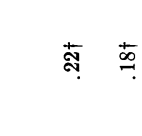 \\
\hline & 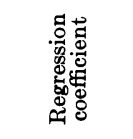 & 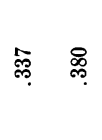 & ज़े & 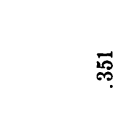 & ๙ึ & 芯 \\
\hline & 死 & 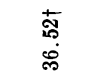 & $\begin{array}{l}\text { 产 } \\
\text { o }\end{array}$ & $\stackrel{\mathscr{2}}{=}$ & $\stackrel{+}{\stackrel{5}{a}}$ & $\stackrel{\infty}{\stackrel{\infty}{\rightarrow}}$ \\
\hline & 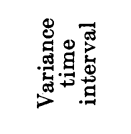 & 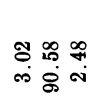 & 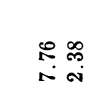 & 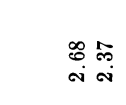 & $\begin{array}{l}\stackrel{\infty}{\infty} \infty \\
\infty \\
\infty\end{array}$ & 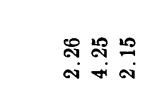 \\
\hline & 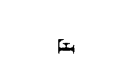 & $\stackrel{8}{\circ}$ & t & $\vdots$ & 葛 & $\vec{a}$ \\
\hline & 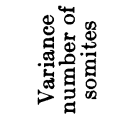 & $\begin{array}{l}\text { Fै \& \& F } \\
\text { in or क }\end{array}$ & 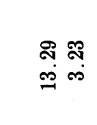 & 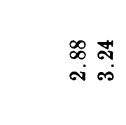 & 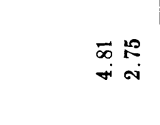 & 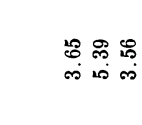 \\
\hline & تُ & 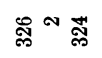 & $0 \underset{\infty}{\infty}$ & $-\bar{m}$ & Nָ & $\vec{\infty}^{\infty} \stackrel{\mathbb{N}}{\mathbb{N}}$ \\
\hline & 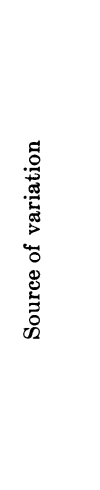 & 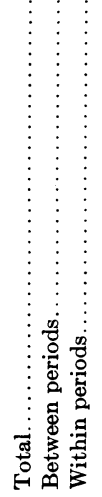 & 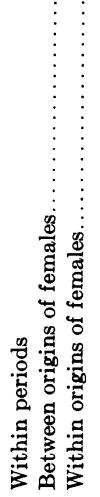 & 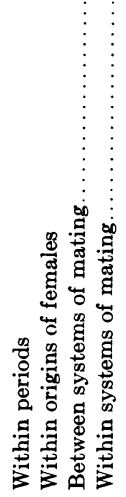 & 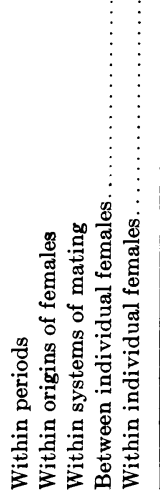 & 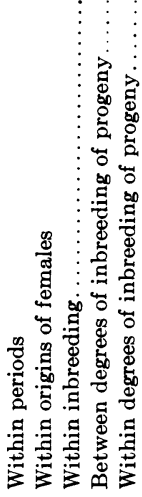 \\
\hline
\end{tabular}


The only disagreement in the two analyses of early embryo size is in the significance of the differences observed between systems of mating. Significant differences in mean blastoderm size were observed between systems of mating in both years, while the differences between systems of mating in mean number of somites were found to be without significance in 1941 and barely significant in 1940.

The main purpose of these analyses was to determine the possible influence of systems of mating on early embryo size. The results indicate that their effects were significant on blastoderm size in both 1940 and 1941, and possibly on number of somites in 1940. The variance ratio in each instance indicates significance at the $5 \%$ level. The effects of systems of mating were definitely not of the magnitude of those caused by origins and individuality of the females, and this led to the further testing of the significance of the effects of systems of mating on early embryo size before accepting the aforementioned results as definite.

The analyses of covariance revealed that origins of females and individuality of the females are the main sources of variation in early embryo size before and after adjustment for regression on time interval. The experimental design followed in these investigations necessitated dividing the females from each origin into three groups which were in turn mated to the same males. It is not illogical to suppose that possibly the three subgroups within each origin of females were not as uniform as was assumed in planning the experiment in view of the highly significant differences observed between individuals within origins. The assumption of uniformity within the subgroups in each origin of females is, however, not necessary, following the demonstration that the variations between periods are all accounted for by the regression of early embryo size on time interval between eggs. The analysis of the effects of systems of mating has therefore been made disregarding periods, by proceeding immediately to the analysis of variance between systems of mating within individuals. The results of this second analysis are presented in table 62 . The same table also contains the results of the analysis of variance of the data on both blastoderm size and number of somites adjusted for their regression on time interval.

The results indicate that systems of mating had a highly significant influence on blastoderm size and a significant influence on number of somites in 1940 ; inbreeding resulted in a smaller blastoderm and in a lower number of somites than outbreeding. No significant difference in either blastoderm size or number of somites was observed between inbreeding and crossbreeding in 1941 (last column, table 62). There is thus contradiction between the results obtained in the two analyses. Results of this last analysis parallel those of the analysis of variance of hatchability where significant differences between systems of mating were observed in 1940 and none in 1941.

A summary of the observations made on early embryo size within each origin of females within each system of mating, in 1940, may help to visualize the results obtained. This summary is presented in table 63 . Inbreeding has consistently resulted in a smaller mean blastoderm and except in one instance, $\mathrm{SE}$ females, in a lower number of somites. The smaller embryo size observed 


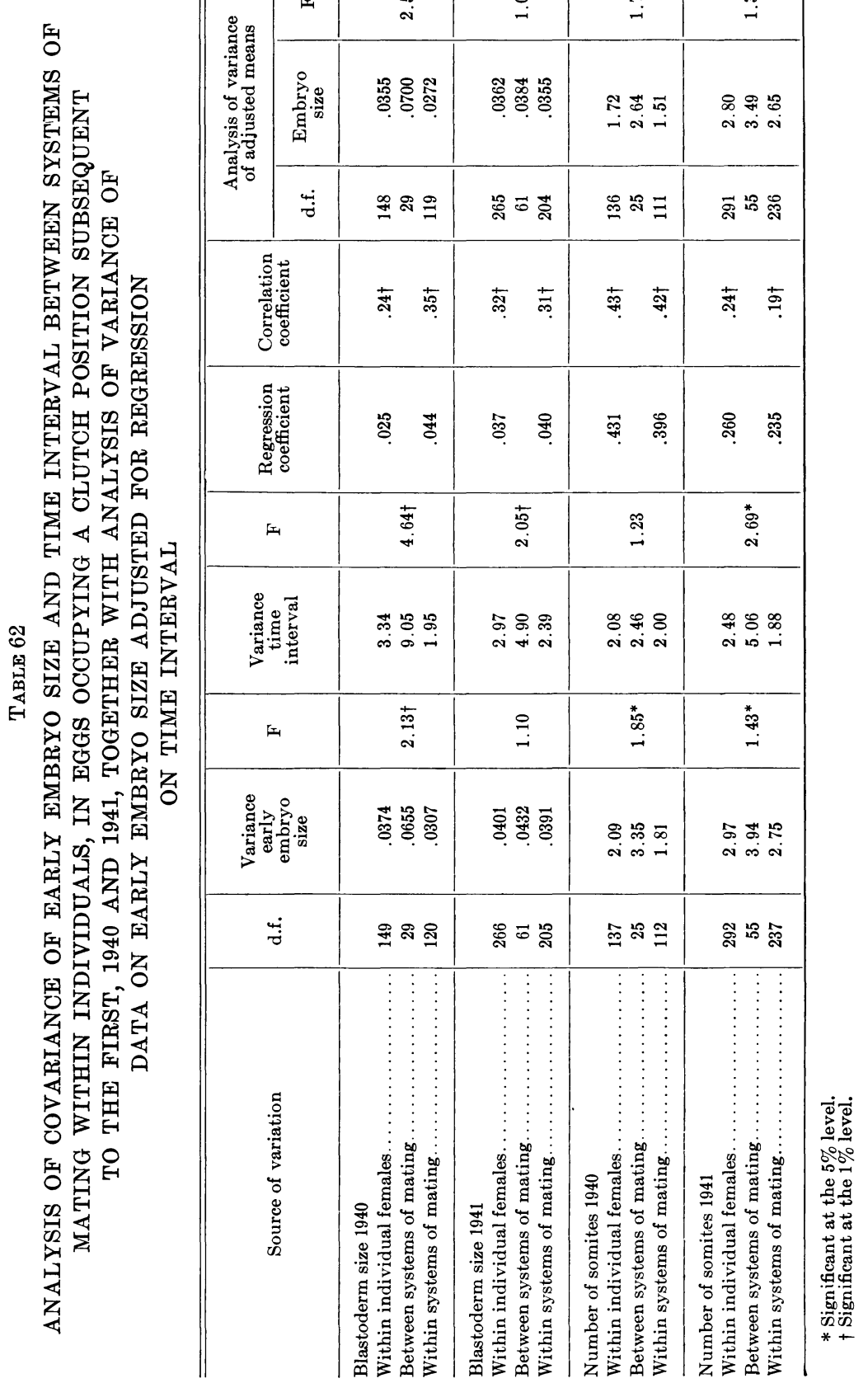


under inbreeding in the $\mathrm{OB}$ females is particularly striking in view of the limited variability in mean time interval under the three systems of mating. An analysis of covariance of early embryo size and time interval between systems of mating within origins of females, as reported in table 64, has, however, revealed no significant difference. This is very likely accounted for by the small number of observations available within each origin.

TABLE 63

MEAN EARLY EMBRYO SIZE OBSERVED UNDER VARIOUS SYSTEMS OF MATING WITHIN EACH ORIGIN OF FEMALES, IN EGGS OCCUPYING A CLUTCH POSITION SUBSEQUENT TO THE FIRST, 1940

\begin{tabular}{|c|c|c|c|c|}
\hline \multirow{2}{*}{ System of mating } & \multirow{2}{*}{ Measurement } & \multicolumn{3}{|c|}{ Origins of females } \\
\hline & & $\mathrm{SE}$ & $\mathrm{OB}$ & CB \\
\hline Inbreeding & 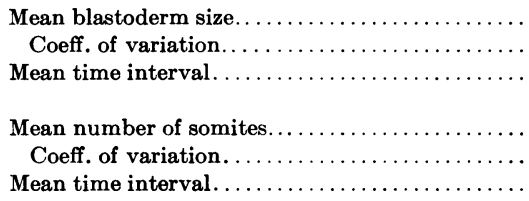 & $\begin{array}{l}3.4575 \\
5.32 \\
25: 45 \mathrm{hrs} \text {. } \\
\\
11.00 \\
19.64 \\
26: 45 \mathrm{hrs} \text {. }\end{array}$ & $\begin{array}{l}3.5597 \\
7.64 \\
24: 39 \mathrm{hrs} . \\
\\
10.11 \\
18.50 \\
25: 00 \mathrm{hrs} \text {. }\end{array}$ & $\begin{array}{l}3.2850 \\
6.62 \\
27: 18 \mathrm{hrs} . \\
9.44 \\
11.97 \\
27: 00 \mathrm{hrs} .\end{array}$ \\
\hline Outcrossing & 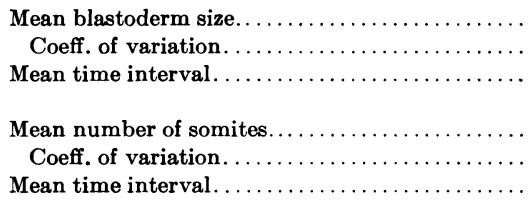 & $\begin{array}{l}3.7010 \\
3.94 \\
25: 54 \mathrm{hrs} . \\
\\
11.11 \\
19.80 \\
26: 54 \mathrm{hrs} .\end{array}$ & $\begin{array}{l}3.6543 \\
5.82 \\
24: 31 \mathrm{hrs} \text {. } \\
10.80 \\
15.37 \\
24: 55 \mathrm{hrs} \text {. }\end{array}$ & $\begin{array}{l}\ldots \ldots \ldots \\
\ldots \ldots \ldots \\
\ldots \ldots \ldots \\
\ldots \ldots \ldots \\
\ldots \ldots \ldots \\
\ldots \ldots \ldots\end{array}$ \\
\hline Crossbreeding & 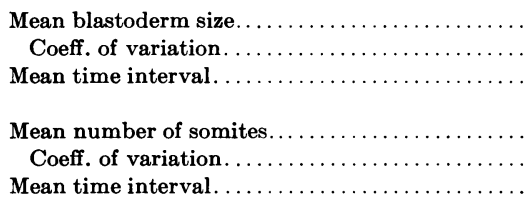 & $\begin{array}{l}3.78 \\
3.28 \\
28: 00 \mathrm{hrs} . \\
\\
10.83 \\
22.90 \\
28: 00 \mathrm{hrs} \text {. }\end{array}$ & $\begin{array}{l}3.5905 \\
6.14 \\
24: 31 \mathrm{hrs} \text {. } \\
\\
10.38 \\
17.24 \\
24: 43 \mathrm{hrs} \text {. }\end{array}$ & $\begin{array}{l}3.4459 \\
6.46 \\
26: 07 \mathrm{hrs} . \\
10.00 \\
15.10 \\
26: 08 \mathrm{hrs} .\end{array}$ \\
\hline All systems & 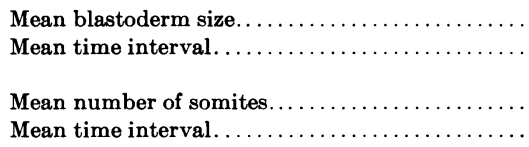 & $\begin{array}{l}3.6855 \\
26: 38 \mathrm{hrs} \text {. } \\
11.00 \\
27: 13 \mathrm{hrs} \text {. }\end{array}$ & $\begin{array}{l}3.6079 \\
24: 33 \mathrm{hrs} \text {. } \\
10.49 \\
24: 52 \mathrm{hrs} \text {. }\end{array}$ & $\begin{array}{l}3.3863 \\
26: 33 \mathrm{hrs} . \\
\\
9.79 \\
27: 00 \mathrm{hrs} \text {. }\end{array}$ \\
\hline
\end{tabular}

The complete parallel between the results of the analysis of the observations on early embryo size and those on hatchability, which is analyzed in greater detail in part $\mathrm{V}$, has led to the following interpretation of the reduced mean embryo size observed following inbreeding: it may be the result of actual or impending early embryonic mortality. Some of the blastoderms and some of the early embryos, in which somites were counted, produced by inbred matings may have been retarded because of impending mortality. These observations on moribund embryos would result in a smaller mean blastoderm diameter and lower mean number of somites. This in turn would 


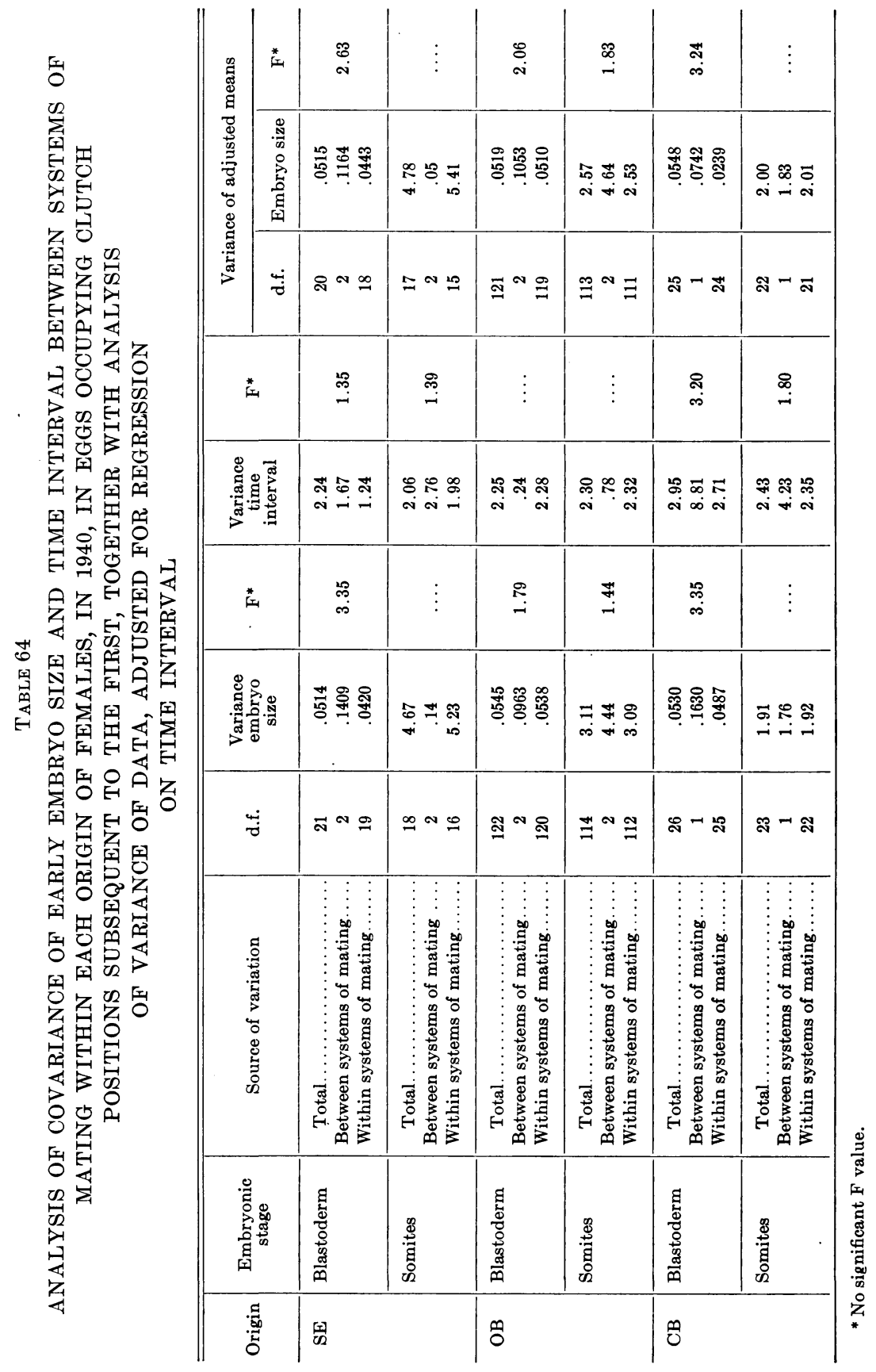


result in greater variability in early embryo size in inbred matings as compared to outbred matings. The analysis of the data, as reported in table 63, shows that the coefficients of variability for blastoderm size were greater under inbreeding in all three origins and were also greater for number of somites in the $\mathrm{OB}$ origin. The coefficients of variability reported in the latter origin are probably the most reliable for purposes of comparison, in view of the greater number of observations on which they are based and also because of the insignificant variation in mean time interval observed under the different systems of mating. The coefficients of variability for both blastoderm size and number of somites are decidedly greater when the OB females were inbred as compared to when they were either outbred or crossbred. There is some indication that the smaller embryo size observed following inbreeding is related to early embryonic mortality or reduced growth rate because of impending embryonic mortality.

\section{DISCUSSION}

The results obtained in this part of the study of the relative effects of inbreeding and outbreeding on early embryo size, indicate that inbreeding results in a smaller mean blastoderm size at time of oviposition, and in a lower number of somites in the embryo after 38 hours of incubation, as compared to outcrossing and crossbreeding. Outcrossing results in a larger mean blastoderm size and in a higher mean number of somites than crossbreeding. Statistically significant differences in early embryo size, between systems of mating, however, were observed in 1940 and not in 1941. In the latter year, the difference observed in early mean embryo size between inbreeding and outbreeding was in the same direction, in favor of outbreeding, as that observed in 1940, but it was not statistically significant. This discrepancy in results is probably explained by differences in the genotypes of the birds used in the two years.

In 1940, the OB females with an outbred origin were probably heterozygous for a large number of genes with deleterious effects. These OB females when inbred to their full brothers were thus likely to produce a considerable proportion of zygotes homozygous for deleterious genes. Some of these genes may have influenced early embryo size, and the result was a significant difference in mean early embryo size between systems of mating.

In 1941, the SEOB females, which provided most of the data, had a topincross origin, inbred SE males on OB females in 1940, and presumably carried fewer deleterious genes than the outbred OB females used in 1940 . The inbreeding in the history of the SE origin may have resulted in the elimination of a number of deleterious genes, and the surviving SE individuals may have been comparatively more homozygous for desirable alleles than the $\mathrm{OB}$ females. Inbreeding of SEOB females would then likely result in a smaller proportion of zygotes homozygous for deleterious genes than in the early stages of inbreeding of the OB females. As a result of this smaller proportion of zygotes homozygous for deleterious genes, mean early embryo size in the SEOB females would not be affected enough to show significant differences between systems of mating. 
It must be stressed that inbreeding consistently resulted in a smaller mean embryo size in both years and in each origin of females, but the differences observed between inbreeding and outbreeding were statistically significant only in 1940 when one of the breeding lines had an outbred origin. The breeding history of the respective origins of females, as influencing their comparative heterozygosity for deleterious genes, would apparently account for the level of significance of the differences in early embryo size observed following inbreeding and outbreeding. The higher the heterozygosity of a group of birds, the greater the probability that inbreeding will bring to light a large number of deleterious genes, and conversely, the higher the homozygosity of a group of birds, the lower the probability that further inbreeding will result in the appearance of homozygotes for deleterious genes. This could very well be interpreted as indicating that with increasing homozygosity, a larger number of observations on many matings are needed to detect the effect of deleterious genes on a character such as early embryo size.

No definite information is available on the actual mode of operation of the genes with deleterious effects on early embryo size, but the following hypotheses are offered.

Inbreeding may result either in a delay in the initiation of cell proliferation after fertilization or cell proliferation may actually proceed at a slower rate in the embryos. No evidence is available to reject either hypothesis in these investigations. They receive some support from the observations of Byerly (1934) to the effect that inbred embryos tend to require more than 21 days to complete their development and hatch. A third hypothesis seems to receive very good support from the evidence obtained in this study. The smaller mean blastoderm size and lower mean number of somites observed following inbreeding may actually be the result of growth retardation, itself a manifestation of impending mortality, caused by deleterious genes. If this hypothesis were true, wholly or partly, rate of impending embryonic mortality and not embryonic growth rate proper should possibly have been measured in these investigations. This hypothesis would lead to an expected greater variability in early embryo size in inbred matings ; this was demonstrated as a fact particularly in the OB origin of females in 1940. In addition, the hypothesis of impending embryonic mortality would result in some degree of correlation between early embryo size and hatchability, a point reported upon in part V.

\section{Other Factors Affecting Early Embryo Size}

Prior to the analysis of the relative effects of inbreeding and outbreeding on early embryo size, as measured by maximum diameter of the blastoderm and number of somites developed in the embryo after 38 hours of incubation, a number of factors were investigated to establish their possible influence on early embryo size. The purpose of these preliminary investigations was to determine which factors had to be taken into account in the analysis of the relative effects of inbreeding and outbreeding on early embryo size. Since a number of very interesting conclusions have been derived, it seems worth while to discuss them as they help to elucidate a number of problems which have received contradictory answers from other investigators. 
Time Interval. A positive and linear correlation was observed between early embryo size and the time interval between the oviposition of the egg in which early embryo size was determined and that of the preceding egg in the same clutch. Scott and Warren (1936) and McNally and Byerly (1936) have also reported a linear relation between time interval and number of somites after 38 and 48 hours of incubation respectively. In the present investigations, the correlation between time interval and early embryo size was higher when number of somites after 38 hours of incubation was used as a measurement than when blastoderm diameter was used. This fact would in turn indicate that the number of somites is a better index of the actual length of time the embryo has been developing either in or ex utero, when the eggs have been kept under similar environmental conditions. The closer relation between length of time interval and number of somites is also relatively easy to understand from the standpoint of embryology. The blastoderm does not increase consistently in diameter at the time of gastrulation, but also differentiates in depth by delamination. Actually, the greater variability between blastoderms in unincubated eggs, or at time of oviposition, may be in degree of delamination rather than in diameter. The somites, in contrast to blastoderm size, represent primarily the result of longitudinal differentiation and hence, as reported previously from the statistical analysis of Fischel's data, the number of somites bears a definite relation to embryo length. In view of the greater accuracy of number of somites as a measure of length of period of development at an early stage, and also the simplicity and rapidity with which somite counts can be made as compared to measurements of blastoderm diameter, it is suggested that number of somites be used in any investigation in which a measurement of early chick embryo size is needed.

The high relation observed between time interval and early embryo size is also evidence in support of the observation of Warren and Scott (1934, $1935 a$, and 1935b) that ovulation is synchronized with the oviposition of the preceding egg in a clutch. It is also evidence in support of the conclusion of Olsen (1942) that fertilization of the hen's ovum normally takes place very shortly after ovulation.

Eggs occupying the first position in a clutch did not show any significant correlation between time interval, as measured by the length of time elapsing from the oviposition of the last egg in the preceding clutch to the oviposition of the first egg of a given clutch, and early embryo size, although there was an indication that a longer interval between clutches resulted in a larger mean embryo size. The lack of a significant relation between time interval separating two clutches and early embryo size is interpreted as evidence that the first egg of a clutch is ovulated at an irregular interval after the last egg of the preceding clutch is laid. Support for this interpretation is found in the greater variability observed in early embryo size in eggs occupying first clutch position. In addition to showing greater variability in early embryo size, eggs occupying the first position of a clutch also averaged larger in mean blastoderm size and higher in mean number of somites than eggs in clutch positions subsequent to the first. Taylor and Gunns (1935) originally made a similar observation. The larger early mean embryo size observed in 
eggs occupying a first clutch position is interpreted as being caused by a longer period of retention in the oviduct before oviposition. Presumably the first egg of a clutch is often ready to be laid during the night, before the hen gets off the roost, and the egg is usually retained in the oviduct until the hen can enter a nest. Scott and Warren (1936) have obtained evidence that the first egg of a clutch spends a longer period of time in the oviduct than subsequent eggs, although they could not detect any resulting difference in the number of somites present in the embryos after 38 hours of incubation.

The second egg in a clutch was also observed to contain a larger blastoderm and a higher number of somites than eggs occupying clutch positions subsequent to the second. An extended analysis of this relation has, however, revealed that the difference was principally accounted for by the second or last egg in two-egg clutches. Atwood (1929) has demonstrated that the time interval between eggs shortens as the number of eggs in a clutch increases. In the analysis of the data available in the present investigations, this was confirmed by the demonstration that the time interval for the second egg in a clutch is shorter as the length of the elutch increases. In the total number of eggs occupying a second clutch position, there were proportionately more eggs from two-egg clutches than from longer clutches; this resulted in an increase in early embryo size in the second clutch position. The observations made in this study lead to the interpretation that the longer time interval for the second egg in two-egg clutches, and possibly for second eggs in other short clutches, is at least partly the result of a longer period of sojourn in the oviduct. The longer time interval of the second egg in two-egg clutches does not represent solely a delay in ovulation since it is expressed in a larger blastoderm and a higher number of somites. This observation is contrary to the conclusion of MeNally and Byerly (1936) that eggs in two-egg clutches did not spend in the oviduct the time indicated by the length of their time interval. They based this conclusion on the inverse relation they observed between time interval and number of somites when the time interval exceeded 27 hours. The observations analyzed in the present study gave results in agreement with the conclusions of Warren and Scott (1935b) that the differences in length of time interval between eggs are due to variations in the time the eggs spend in the uterus.

The last egg in a clutch was observed to have a longer time interval and to contain a larger blastoderm and an embryo with a higher number of somites than eggs in a clutch position intermediate to the first and the last. Atwood (1929) and more recently Berg (1945) have reported that the last egg in a clutch has a longer time interval. Berg (1945) was also able to conclude that this longer time interval represents a longer period of sojourn in the uterus because of the comparatively thicker shell on the last egg in a clutch. The data analyzed in the present study furnish additional evidence to support Berg's conclusion since the last egg in a clutch contained a larger blastoderm and developed an embryo with a larger number of somites after 38 hours of incubation. In the preceding paragraph on eggs occupying the second position in a clutch, it was stated that the larger early embryo size observed in such eggs was accounted for by the last or second egg in two-egg 
clutches. This same explanation could apply here also, since a great proportion of the total number of last eggs will be from two-egg clutches. It was found, however, that even after the elimination of the last or second egg in two-egg clutches, the last egg still developed an embryo with a significantly larger number of somites but did not contain a larger blastoderm at oviposition than eggs in intermediate clutch positions. The exact nature of the delay in the oviposition of the last egg is not known, but it could be caused by the lack of the stimulus accompanying the ovulation of a succeeding egg. It has generally been assumed that, because ovulation follows the oviposition of the preceding egg, the former takes place as a result of the stimulus provided by the latter, but the contrary also seems possible in view of the observations on the prolonged retention of the last egg of a clutch.

Time of Lay. Eggs laid early in the morning, particularly those laid at or before 8 o'clock, were observed to contain larger blastoderms and to develop embryos with a higher number of somites than eggs laid later in the day. The eggs laid at or before 8 o'clock in the morning not only developed larger embryos but these were also more variable in size than those in eggs laid later in the day. This observation is explained by the fact that $80 \%$ of the eggs laid at or before 8 o'clock were eggs occupying the first position in a clutch and hence had spent a more variable and, on the average, a longer period of time in the oviduct. McNally and Byerly (1936) have also observed that eggs laid before 9 o'clock in the morning contained embryos with a larger number of somites after 48 hours of incubation than eggs laid after 9 o'clock. In this investigation, the eggs laid later in the afternoon, after 2 o'clock, contained somewhat smaller blastoderms but developed embryos with a larger number of somites than eggs laid between noon and 2 o'clock. McNally and Byerly (1936) have reported that eggs laid in the later part of the day developed embryos with a smaller number of somites after 48 hours of incubation than those laid earlier in the day. In the present investigation the eggs occupying the first position in a clutch exhibited no significant relation between hour of lay and number of somites. The eggs in clutch positions subsequent to the first when laid early in the morning (before 9 o'clock) and early in the afternoon (before 2 o'clock) contained embryos with a lower number of somites than those laid later in the morning (after 9 o'clock) and later in the afternoon (after 2 o'clock). In the interpretation of these observations, it is well to remember that eggs in last clutch position are laid later in the afternoon. Since these eggs have been shown to have a longer time interval, representing at least partly a longer period of sojourn in the oviduct, it will not be unlikely that a larger number of somites will appear in eggs laid later in the afternoon.

This discussion has revealed that variations in the length of time the eggs are retained in the oviduct constitute a very important factor to be taken into account in the analysis of observations on early embryo size. It can be stated that in eggs occupying a clutch subsequent to the first, contrary to eggs in first clutch position, the time interval between the oviposition of the preceding egg and the ovulation of the egg in which observations are to be made is an accurate index of the actual time the egg spent in the oviduct. For this 
reason, in the analysis of the relative effects of inbreeding and outbreeding on early embryo size only observations made on eggs occupying a clutch position subsequent to the first were analyzed, since they could be adjusted for their regression on time interval and the various matings hence put on a comparable time interval basis.

Individuality of the Hen. Another factor investigated was the individuality of the hen. Significant differences between individual hens were observed in both mean blastoderm diameter before incubation and mean number of somites after 38 hours of incubation, whether their eggs occupied the first position or a subsequent one in a clutch. These differences between individuals could of course be attributed to variations in length of time interval between eggs, but an analysis of variance of the data on blastoderm size and on number of somites adjusted for their regression on time interval revealed that the differences between individuals were still highly significant. The time interval elapsing between the oviposition of the preceding egg and ovulation of the one in which embryo size was measured does not entirely explain the mean size of the blastoderm or the mean number of somites developed in the eggs of an individual. This fact, however, does not eliminate entirely the possibility that the differences in early embryo size between individual birds may still be the result of variations in length of time the egg has spent in the oviduct. It is true that good evidence has been presented in support of the view that ovulation takes place shortly after the oviposition of the preceding egg, but differences may exist between individuals in the actual time interval elapsing between the two phenomena. The synchronization of oviposition and ovulation would not necessarily be affected by the presence of variations between individuals in the time relation between the two. In fact such individual variations do result as a consequence of variations in rate of egg production, as low intensity of egg production necessarily entails, at least partly, longer time intervals between successive ovulations. These variations could thus account for the significant differences observed in early embryo size between individuals.

The significant differences observed in early mean embryo size between individuals might also be explained in part by slight individual variations in body temperature. If, on the basis of a common time interval, the eggs of individual hens still vary in early embryo size, it is possible that these variations are due to differences in the environment within the hen and the most probable difference is variation in body temperature. Fronda (1925) has observed significant temperature variations between and within individual hens.

Another explanation for the significant variations observed between individual birds in early embryo size is the one offered to account for the significant variations observed between inbreeding and outbreeding. The rate of early embryonic mortality undoubtedly varies in individual birds and hence a varying proportion of the blastoderms and early embryos within individuals would be moribund and retarded in development at the time the observations were made. These varying proportions of moribund or retarded blastoderms and early embryos could result in significant differences in mean early embryo size between individual birds. 
Finally, there is also the possibility of genetic factors which regulate early embryonic growth rate; these would be different from the deleterious genes referred to previously.

\section{SUMMARY}

Inbreeding, when compared to outbreeding, resulted in a smaller mean blastoderm diameter in unincubated eggs and in a lower mean number of somites in embryos after 38 hours of incubation. Outcrossing resulted in a larger mean blastoderm diameter and a higher mean number of somites than crossbreeding. Statistically significant differences in early embryo size between inbreeding and outbreeding were observed in 1940 in a group of birds with an outbred origin that were presumably highly heterozygous. The effects of inbreeding on early embryo size are tentatively explained as the result of homozygous deleterious genes which retard embryonic development and may eventually lead to embryonic mortality. Inbreeding may also result in a delay in the initiation or the rate of embryonic development.

Eggs in first and last clutch positions, laid early in the morning and late in the afternoon respectively, contained embryos comparatively more advanced in development presumably because of the longer period of time these eggs were retained in the oviduct. A linear relation was observed between length of time interval separating the oviposition of two successive eggs and early embryo size.

Significant differences in early embryo size were demonstrated between individuals and these differences remained signficant even after adjustment for regression of early embryo size on time interval. These individual differences were interpreted as possibly due to individual variations in the synchronization between oviposition of the preceding egg and ovulation, slight individual variations in body temperature, genetic factors which may affect early embryonic growth rate, and also individual variations in incidence of early embryonic mortality preceded by a retardation in development. 


\section{The Relative Effects of Inbreeding and Outbreeding on Reproduction in the Domestic Fowl}

\section{PAUL E. BERNIER, LEWIS. W. TAYLOR, and C. A. GUNNS}

\section{INTERRELATIONSHIPS OF CHARACTERS STUDIED}

ONE OF THE OBJECTIVES of the present investigations was to ascertain the presence of possible interrelationships between the characters studied; between fertility and hatchability, between blastoderm size in the unincubated egg and number of somites after 38 hours of incubation, and between early embryo size and hatchability. After the completion of the analysis of the variation in blastoderm diameter and in number of somites, it was clearly evident that these two measurements were very highly correlated and it seemed superfluous to analyze their covariance. Only two interrelationships thus remained to be studied, that between fertility and hatchability, and that between embryo size and hatchability.

\section{Relation Between Fertility and Hatchability}

Contradictory evidence has been reported on the relation between fertility and hatchability of fertile eggs. It was thought that the experimental design used in these investigations, permitting a detailed analysis of the relation between the two characters in females of three different origins mated in turn to males of the same three origins within three successive periods, could possibly shed some light on the problem.

\section{Review of Literature}

Pearl and Surface (1909) observed a small but sensible correlation between fertility and hatchability in Barred Plymouth Rocks, but they concluded that the two characters were biologically independent, a view which has since been held by most investigators in poultry husbandry. Hyre and Hall (1932) reported that hatchability and fertility behave as individual characteristics in hens and that both are fairly constant from year to year. Hays and Sanborn (1924), and Jull (1928) reported that fertility and hatchability were independent. Blyth (1945) commenting on these investigations of Hays and Sanborn, Jull, and Hyre and Hall, expressed the view that any small correlation present in their data may have been obscured by the facts that the observations were made over a short period of time, with relatively large numbers of birds mated to many males, and without knowledge or account of completely infertile matings. 
Knox (1927) and Munro (1938, 1940, 1942, 1946) have observed a positive relation between fertility and hatchability. Landauer (1941) in summarizing studies made on the relation between fertility and hatchability drew attention to the apparent lack of correlation between the two characters in the White Leghorn and Rhode Island Red breeds, but the suggestion of a positive relationship in Barred Plymouth Rocks.

Munro and Kosin (1945), in studies on the relationship between fertility and hatchability over a period of six years in a total of 72 pens of Barred Plymouth Rocks and of 66 pens of White Leghorns, observed correlation coefficients between mean fertility and mean hatchability of pens ranging from .067 to .515 and from .014 to .636 in the Barred Plymouth Rocks and White Leghorns respectively. The net and significant correlation coefficients observed were .332 and .265 for the Barred Plymouth Rocks and the White Leghorns respectively. The relation was observed to be particularly evident between the means of mass-mated pens within single hatches and between the means of different settings from the same pen or groups of pens at different times. As an explanation for the observed relation between fertility and hatchability, Munro and Kosin (1945) suggested a preoviposital embryonic mortality which might ordinarily be misinterpreted as "infertility" and which they assumed to be correlated with postoviposital embryonic mortality. They reported having secured evidence of cellular proliferation in approximately $50 \%$ of so-called "infertile" blastodises. The conclusion of Munro and Kosin was thus that there is a relation between embryonic mortality during the preoviposital period, approximately 26 hours elapsing between fertilization and oviposition, and embryonic mortality during the 21 days of postoviposital embryonic development.

Blyth (1945) observed similarities in the seasonal trends of hatchability and fertility over a period of six months in two consecutive years. She obtained significant correlation coefficients of .9376 between month means, .6651 between bird means, and .2739 between all observations. The variances for embryonic mortality and for infertility corrected for their regression on fertility or embryonic mortality, respectively, remained significant for both month and bird means. Blyth concluded that infertility and embryonic mortality are associated, behave as inherent characteristics of individuals, exhibit similar seasonal changes, and that each variable shows additional significant variations peculiar to itself which tend to obscure the fundamental relationship between them. According to her, seasonal variations in infertility indicate that this infertility may really be undetected embryonic mortality. She added that if true infertility exhibits seasonal trends then it can only occur through parental sources such as variations in the sexual activity of males and cyclic changes in the physiological status of the females.

\section{Materials and Methods}

The data reported on in part II dealing with fertility and in part III dealing with hatchability were used to study the relation between the two variables. In parts II and III the data were weighted within each classification for variation in egg production; unfortunately these figures, being non- 
additive, could not be used in an analysis of covariance. It was therefore necessary to work on the individual percentages of fertility and hatchability converted to angles expressed in degrees and then submitted to a regular analysis of covariance.

\section{Analysis of Observations}

It is not necessary to repeat here the analysis made on fertility and hatchability as the results can be consulted by referring to parts II and III. Essentially the same classifications were used in the analysis of covariance of fertility and hatchability as can be gathered from table 65 .

TABLE 65

ANALYSIS OF COVARIANCE OF FERTILITY AND

HATCHABILITY, 1940 AND 1941

\begin{tabular}{|c|c|c|c|c|}
\hline Source of variation & $\begin{array}{c}\text { Degrees } \\
\text { of freedom }\end{array}$ & $\begin{array}{c}\text { Correlation } \\
\text { coefficient }\end{array}$ & $\begin{array}{l}\text { Regression } \\
\text { coefficient }\end{array}$ & $\begin{array}{c}t \\
\text { value }\end{array}$ \\
\hline 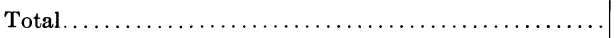 & 59 & $.27^{*}$ & $.2914^{*}$ & 2.17 \\
\hline 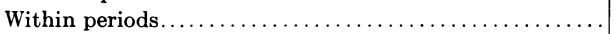 & 57 & .21 & .2354 & 1.65 \\
\hline Between origins $\ldots \ldots \ldots \ldots \ldots \ldots \ldots \ldots \ldots \ldots$ & 6 & .24 & .1496 & 0.56 \\
\hline Within origins $\ldots \ldots \ldots \ldots \ldots \ldots \ldots \ldots \ldots \ldots \ldots \ldots \ldots \ldots \ldots \ldots \ldots \ldots$ & 51 & .22 & .3021 & 1.62 \\
\hline Between systems of mating. . . . . . . . & 14 & -.20 & -.3126 & 0.74 \\
\hline Within systems of mating... & 37 & $.43 \dagger$ & $.5633 \dagger$ & 2.95 \\
\hline 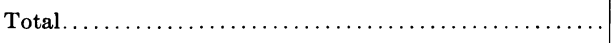 & 107 & .16 & .2706 & 1.59 \\
\hline 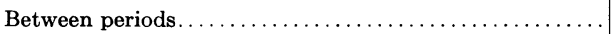 & 2 & .87 & 12.7800 & 1.75 \\
\hline 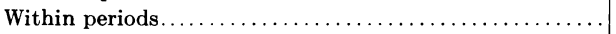 & 105 & .16 & .2890 & 1.77 \\
\hline Between origins . . . . . . . . . . . . & 6 & .25 & .5030 & 0.57 \\
\hline Within origins. . . . . . . . . & 99 & .15 & .2429 & 1.48 \\
\hline Between systems of mating... & 9 & .19 & .2446 & 0.56 \\
\hline Within systems of mating $\ldots \ldots \ldots \ldots \ldots \ldots \ldots$ & 90 & .14 & .2422 & 1.31 \\
\hline
\end{tabular}

* Significant at the $5 \%$ level.

$\dagger$ Significant at the $1 \%$ level.

The correlation coefficient observed between fertility and hatchability when all matings were considered, irrespective of classification, was .27 and .16 for 1940 and 1941 respectively. The former, .27, observed in 1940, was the only significant one at the $5 \%$ level. The regression coefficients observed were .2914 and .2706 for 1940 and 1941 respectively. The former, as was the case for the correlation coefficient, is the only one that gave a $t$ value significant at the $5 \%$ level of significance.

Seasonal Variation. The analysis of covariance of fertility and hatchability between periods gave correlation coefficients of .87 and .81 in 1940 and 1941 respectively but both coefficients are nonsignificant. The regression coefficients observed were .6588 and 12.78 for 1940 and 1941 respectively, and both also were nonsignificant. 
The correlation coefficients within periods remained practically the same as in the total, .21 and .16 as compared to .27 and .16 for 1940 and 1941 respectively. The same observation applies to the regression coefficients, .2354 and .2890 for 1940 and 1941 respectively as compared to .2914 and .2706. Neither the correlation nor the regression coefficients observed within periods reach a level of significance.

Origins of Females. The next step in the analysis of covariance was to ascertain whether the three origins of females showed differences in the relation between fertility and hatchability. The correlation coefficients observed

TABLE 66

ANALYSIS OF COVARIANCE OF FERTILITY AND HATCHABILITY WITHIN ORIGIN OB IN 1940

\begin{tabular}{|c|c|c|c|}
\hline Source of variation & $\begin{array}{l}\text { Degrees } \\
\text { of freedom }\end{array}$ & $\begin{array}{l}\text { Correlation } \\
\text { coefficient }\end{array}$ & $\begin{array}{l}\text { Regression } \\
\text { coefficient }\end{array}$ \\
\hline All OB females. . & 29 & .20 & .1991 \\
\hline Between subgroups or pens.. & 2 & -.10 & -.2551 \\
\hline Within subgroups or pens... & 27 & .20 & .2014 \\
\hline Between systems of mating.. & 6 & -.44 & -.5543 \\
\hline Within systems of mating... & 21 & -.05 & -.0350 \\
\hline
\end{tabular}

were .24 and .25 for 1940 and 1941 respectively while the regression coefficients were .1496 and .5030 . None of the coefficients reached the level of significance.

Systems of Mating. The analysis of covariance of fertility and hatchability between systems of mating, within origins of females and within periods, gave correlation coefficients of -.20 and +.19 in 1940 and 1941 respectively. The regression coefficients observed were -.3126 and +.2446 . Again none of these coefficients reached the level of significance. The remaining figures, termed "within systems of mating" and which could be designated between individuals, showed correlation coefficients of .43 and .14 in 1940 and 1941 respectively while the regression coefficients were .5633 and .2422 . The correlation and regression coefficients observed in 1940 were both significant at the $1 \%$ level.

Covariance within OB Origin. In the analysis of variance of hatchability it was established that the $O B$ origin was the group of birds which showed very significant differences in hatchability between systems of mating. In view of this observation it was thought advisable to study further the relation between fertility and hatchability in this group of birds. An additional argument in favor of more detailed analysis of the data obtained with this group of birds is that their production was much more uniform. A first analysis, which is reported in table 66 , dealt with the covariance of hatchability between and within three subgroups of $O B$ birds, which were in separate pens, and between and within systems of mating. The overall correlation between fertility and hatchablity in the OB group of birds was .20 while the regression coefficient was .1991; both nonsignificant. No significant difference in the correlation coefficient was observed between the three subgroups 
$(-.10)$, or within them (.20). When the data for each subgroup were analyzed for the covariance of fertility and hatchability between systems of mating, the correlation coefficient observed was -.44 while the regression coefficient was -.5543. Within systems of mating, or, in equivalent terms, between individual birds, the correlation coefficient observed was -.05 and the regression coefficient -.0350 . None of the correlation or regression coefficients reached a level of significance.

An additional method of analysis of the data obtained with the $\mathrm{OB}$ origin was applied. It consisted of dealing with each bird directly and determining the covariance of fertility and hatchability within birds. The latter term has however the inconvenience of covering both systems of mating and seasonal

TABLE 67

ANALYSIS OF COVARIANCE OF FERTILITY AND HATCHABILITY WITHIN INDIVIDUAL OB BIRDS IN 1940

\begin{tabular}{|c|c|c|c|}
\hline Source of variation & $\begin{array}{l}\text { Degrees } \\
\text { of freedom }\end{array}$ & $\begin{array}{l}\text { Correlation } \\
\text { coefficient }\end{array}$ & $\begin{array}{l}\text { Regression } \\
\text { coefficient }\end{array}$ \\
\hline All OB females................ & 26 & .15 & .1543 \\
\hline Between individuals $\ldots \ldots \ldots \ldots \ldots \ldots \ldots \ldots$ & 8 & .06 & .1177 \\
\hline $\begin{array}{l}\text { Within individuals or between systems of } \\
\text { mating and periods. } \ldots \ldots \ldots \ldots \ldots \ldots \ldots \ldots\end{array}$ & 18 & .21 & .1607 \\
\hline
\end{tabular}

variation. The results of this method of analysis are presented in table 67 . The correlation coefficient observed in the total was .15 while the regression coefficient was .1543. The analysis of covariance between individual birds gave a correlation coefficient of .06 and a regression coefficient of .1177 . The remainder, within individual birds, which as stated above also covers between systems of mating and between periods, gave a correlation coefficient of .21 and a regression coefficient of .1607. Again none of the correlation or regression coefficients were significant.

\section{DISCUSSION}

The most striking feature in this analysis of covariance of fertility and hatchability is undoubtedly the similarity between the correlation coefficients reported here on all observations (.27 and .16) and those reported by Munro and Kosin (1945) (.27 for White Leghorns) and by Blyth (1945) (.27 for Brown Leghorns). The second striking feature is also a similarity between the correlation coefficients observed in the present study between periods (.81 and .87) and the value reported by Blyth (1945) (.94) between sixmonth means. The prevalent opinion of hatcherymen and practical poultrymen as to the existence of a relation, seasonal in character, between fertility and hatchability, seems supported by the investigations of Munro and Kosin (1945), Blyth (1945), and to a certain degree by the present study. It is necessary to emphasize that the correlation coefficients reported here between periods, notwithstanding their magnitude, did not reach a level of significance.

The present investigations presented some advantages over previous studies 
in that further analysis could be made on the basis of genetic relationship and also of systems of mating in an effort to elucidate the general relationship observed between fertility and hatchability. Embryonic mortality could be both genetical and environmental in origin and presumably the hypothesis of preoviposital mortality, suggested by Munro and Kosin (1945), could hold for both types of mortality. Should the hypothesis of preoviposital mortality hold for embryonic mortality of genetic origin, then it might be possible to detect differences in the relationship between fertility and hatchability in groups of birds of different origins and genetic constitution or in birds submitted to different systems of mating.

The results obtained in the present study show that origin or genetic relationship and also systems of mating do not change or alter the general relationship between fertility and hatchability. Two noticeable exceptions to this conclusion were observed. In 1940 a negative correlation coefficient was noted between systems of matings; this is explained by the OB birds which when inbred showed no noticeable difference in fertility, but a significant decrease in hatchability, hence a negative correlation. This negative correlation instead of supporting Munro and Kosin's hypothesis negates it. The other significant exception was observed within systems of mating in 1940. The significant correlation coefficient reached a value of .43. As stated previously the "within systems of mating" classification is equivalent to "between individual birds." Hence in 1940 within a given mating system, dams with better fertility also gave better hatchability. This was not the case in 1941. Since the population of 1940 had a greater number of individuals of inbred origin than that of 1941 , it is possible that this difference may be responsible for the higher correlation coefficient between fertility and hatchability observed in the former year.

The relationship observed between fertility and hatchability, significant at the $5 \%$ level in one year only, is apparently not explained by genetic variability but possibly by environmental variability peculiar to that year or to the birds mated that year. The physiological condition of both males and females apparently shows seasonal variations resulting in variations in fertility. Seasonal variations also affect the hatching quality of eggs laid by the females.

\section{Relation Between Early Embryonic Growth and Hatchability}

In the analysis of the data on hatchability obtained in the present investigations, the hypothesis that the smaller mean blastoderm size and the lower mean number of somites observed under inbreeding are the results of growth retardation, itself a manifestation of impending embryonic mortality, was proposed. This hypothesis could be tested by an analysis of the relationship between early embryo size and hatchability.

\section{Review of Literature}

Interest in the relationship between early embryo size and hatchability stems from Stockard's (1921) hypothesis that nonhereditary monstrosities result from arrests in development. Since the development of birds is discontinuous, being interrupted at about the gastrulation stage, Stockard was 
led to suggest that the abundant occurrence of double chick embryos and the well known high embryonic mortality are due to this natural arrest of development. The variations in development of the blastoderm in hens' eggs at the time of laying would account for the double individuals and twins among chick embryos as well as for their apparent frequency. Riddle (1923) failed to obtain double embryos by cooling premature eggs of ring doves, but he observed that eggs with fully formed shells retained in the uterus cannot obtain enough oxygen to satisfy the demands of the embryo during the postgastrula stage and consequently die. Hutt and Greenwood (1929) expressed the view that variation in time required by the egg to traverse the oviduct results in differences in development at the time the egg is laid. Hutt and Pilkey (1930) observed a significantly higher $(3.89 \%)$ mortality rate of embryos in eggs laid in the afternoon. They explained that among eggs laid in the morning there would be a greater proportion which have been held in the body longer than the normal period and are therefore safely past the critical gastrulation stage. Nicolaides (1933) reported that eggs further advanced in development at time of laying generally hatch better than others regardless of hour laid. Hays and Nicolaides (1934) observed that the most common embryonic stages in eggs at time of laying are pregastrula and early gastrula for hens with low hatchability and well advanced gastrula for highhatching hens. Taylor and Gunns $(1935,1939)$ were unable to detect any significant correlation between blastoderm characteristics in unincubated eggs and hatchability of other eggs from the same hens with the exception of a positive relation between extent of overgrowth and hatchability. Bronkhorst (1933) observed that the maxima of growth generally occurred earlier among the embryos of the high-hatching hens than among the low-hatching hens. Landauer (1941) pointed out that it is impossible to judge from Bronkhorst's data whether the observed differences indicate that retarded growth was a causal factor in reduced hatchability or whether the reduced size of the embryos is an expression of retardation preceding death from unanalyzed causes, such as would occur as a result of nutritional deficiencies. MeNally and Byerly (1936) reported that hens whose eggs contained embryos with 20 somites after 48 hours of incubation gave the maximum hatchability, while there was a gradual decrease in hatchability as the embryos had from 20 to 14 somites and a rapid decrease in hatchability as the number of somites increased from 20 to 23 . Neel (1942) reported a correlation coefficient of $+.77 \pm .08$ between rate of development and percentage of hatchability for individual hens, but it may be suspected that the correlation reported by him is a spurious one since his "rate of development" probably represents the average developmental stage not only of normal living embryos but also moribund and dead ones. Sturkie and Williams (1945) obtained premature eggs from hens and subsequently incubated them. The blastoderms of eggs $131 / 2$ hours after fertilization were very susceptible to the development of abnormalities, while blastoderms only one hour older were not as susceptible, as a higher percentage resumed normal development when under normal incubation. Sturkie and Williams conclude that eggs laid several hours prematurely showed a high degree of resistance to changes in milieu and that in view of this 
fact it is not surprising to find that the variations observed in the state of development of normally laid eggs are not significantly related to degree of hatchability.

\section{Materials and Methods}

The data reported in part III dealing with hatchability and in part IV dealing with early embryonic growth were used to study the relation between these two variables. As was the case in the analysis of the relationship between fertility and hatchability, it was necessary to work on individual percentages of hatchability converted to angles expressed in degrees and then submitted to a regular analysis of covariance.

TABLE 68

SUMMARY OF DATA ON HATCHABILITY AND EARLY EMBRYO

SIZE CLASSIFIED ACCORDING TO CLUTCH POSITION, TIME INTERVAL BETWEEN EGGS, AND HOUR

OF LAY, SHOWING THEIR RELATIONSHIP

\begin{tabular}{|c|c|c|c|}
\hline Classification & $\begin{array}{c}\text { Mean blastoderm } \\
\text { size of unincu- } \\
\text { bated eggs in mm }\end{array}$ & $\begin{array}{l}\text { Mean number of } \\
\text { somites in eggs } \\
\text { incubated } 38 \mathrm{hrs} \text {. }\end{array}$ & $\begin{array}{l}\text { Mean percentage } \\
\text { hatchability of } \\
\text { fertile eggs }\end{array}$ \\
\hline \multicolumn{4}{|l|}{ Clutch position } \\
\hline First. . . . . . . . . & $3.7761 \pm .0158$ & $12.6389 \pm .1152$ & 75.98 \\
\hline Subsequent to first... & $3.5431 \pm .0079$ & $11.3956 \pm .0618$ & 79.79 \\
\hline \multicolumn{4}{|l|}{$\begin{array}{l}\text { Time interval between eggs in clutch positions sub- } \\
\text { sequent to the first }\end{array}$} \\
\hline $20-22$ hours $\ldots \ldots \ldots \ldots \ldots \ldots \ldots \ldots \ldots \ldots \ldots \ldots \ldots \ldots \ldots$ & 3.4643 & 9.6238 & 75.00 \\
\hline 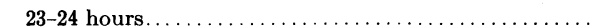 & 3.4943 & 10.5917 & 78.38 \\
\hline 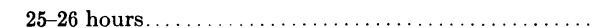 & 3.5025 & 11.5238 & 78.50 \\
\hline $27-28$ hours $\ldots \ldots \ldots \ldots \ldots \ldots \ldots \ldots \ldots \ldots \ldots \ldots \ldots$ & 3.5393 & 11.8029 & 73.33 \\
\hline 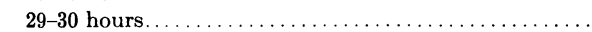 & 3.5923 & 13.0000 & 40.00 \\
\hline 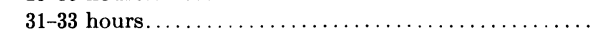 & 3.6833 & ....... & $\ldots .$. \\
\hline \multicolumn{4}{|l|}{ Hour of lay } \\
\hline Before 8 o'clock.... & 3.7565 & 12.2558 & 68.29 \\
\hline 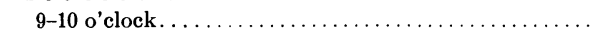 & 3.6675 & 11.4118 & 81.69 \\
\hline $11-12$ o'clock. . . . & 3.5609 & 11.5375 & 77.55 \\
\hline $1-2$ o'clock $\ldots \ldots \ldots \ldots \ldots \ldots \ldots \ldots \ldots \ldots \ldots$ & 3.5947 & 11.8226 & 77.22 \\
\hline 3 o'clock and later $\ldots \ldots \ldots \ldots \ldots \ldots \ldots \ldots$ & 3.5689 & 12.1177 & 68.99 \\
\hline
\end{tabular}

\section{Analysis of Observations}

The pertinent data on hatchability and early embryonic growth are grouped together in table 68. Eggs occupying the first clutch position contain a larger blastoderm and a 38-hour embryo with more somites than eggs occupying subsequent clutch positions. These eggs in the first clutch position also do not hatch as well as those in subsequent clutch positions. Eggs with a time interval of less than 23 hours contain a smaller blastoderm and an embryo with less somites and do not hatch quite as well as eggs with a time interval of 23 to 29 hours. Eggs with a time interval of 29 hours or more contain a larger blastoderm and an embryo with more somites and do not hatch as well as eggs with a time interval of less than 29 hours, but more than 22 hours. Eggs laid before 8 o'clock in the morning contain a larger blas- 
toderm and an embryo with more somites than those laid later in the day while eggs laid after 3 o'clock in the afternoon contain a smaller blastoderm than those laid earlier in the day. Both these groups of eggs do not hatch as well as those laid after 8 o'clock and before 2 o'clock. This evidence points to a curvilinear relationship between early embryo size and hatchability.

The next step consisted of an analysis of covariance of hatchability and early embryo size, as measured by blastoderm diameter in the unincubated egg and number of somites in the embryo after 38 hours of incubation (table 69). First, the data gathered in 1940 and 1941 were pooled irrespective of clutch position. A significant correlation coefficient was obtained between number of somites and hatchability (.18). In the pooled data and irrespective of clutch position, but under inbreeding, a significant correlation coefficient was again observed only between number of somites and hatchability (.24). In the first clutch position no significant correlation was observed between either of the measurements of early embryo size and hatchability. In clutch positions subsequent to the first, a significant correlation coefficient was observed between number of somites and hatchability under inbreeding only.

A parallel analysis of covariance was then separately conducted for the data collected in each of the two years. None of the correlation coefficients observed reached a level of significance.

It was observed earlier that the relationship between early embryo size and hatchability appeared to be curvilinear in nature and for that reason a test of linearity was made. The data gathered in 1940 were used for this analysis. No significant departure from linearity was found.

It is recalled that the only significant differences in hatchability and in early embryo size between systems of mating were observed in 1940. In that year the OB origin of females was the only group of birds with significant differences in hatchability between systems of mating. In view of these facts, the $\mathrm{OB}$ origin of females seemed to provide excellent material for testing the hypothesis previously enunciated : that the smaller mean blastoderm size and the lower mean number of somites observed under inbreeding are the results of growth retardation or impending embryonic mortality.

The mean blastoderm size and mean number of somites observed in each mating (each hen in turn mated to three sets of males) were correlated with the percentage of hatchability observed in the same mating. Three sets of observations on blastoderm size and three on number of somites were available. A mean was determined for all eggs irrespective of clutch position, another was obtained from observations made on eggs occupying first clutch position, and finally, another was based on the measurements made on eggs occupying a clutch position subsequent to the first.

The results of the analysis of covariance are presented in table 70. The relation between early embryo size and hatchability is positive in the individual matings of the $\mathrm{OB}$ origin of females in 1940. Large mean blastoderm size and large mean number of somites were indicative of high hatchability in a given mating. The most interesting fact is undoubtedly the increase in the value and significance of the correlation coefficients as the embryos increase 
in age. In eggs occupying a clutch position subsequent to the first, and in which embryonic development has been under way in the oviduct for approximately 26 hours, the correlation is .10, not significant but indicative of a trend. In eggs occupying first clutch position, which are known to have remained

TABLE 69

\section{ANALYSIS OF COVARIANCE OF HATCHABILITY AND EARLY EMBRYO SIZE, DATA OF 1940 AND 1941}

\begin{tabular}{|c|c|c|c|}
\hline Source of data & $\begin{array}{l}\text { Embryonic } \\
\text { stage }\end{array}$ & $\begin{array}{l}\text { Number } \\
\text { of matings }\end{array}$ & Correlation \\
\hline \multicolumn{4}{|l|}{1940 and 1941} \\
\hline \multirow[t]{2}{*}{ All clutch positions.. } & Blastoderm & 153 & .038 \\
\hline & Somites & 153 & $.181 *$ \\
\hline \multirow[t]{2}{*}{ Under inbreeding. } & Blastoderm & 73 & .074 \\
\hline & Somites & 74 & $.244^{*}$ \\
\hline \multirow[t]{2}{*}{ First clutch position.. } & Blastoderm & 107 & -.027 \\
\hline & Somites & 105 & .160 \\
\hline \multirow[t]{2}{*}{ Under inbreeding. } & Blastoderm & 54 & .144 \\
\hline & Somites & 56 & .196 \\
\hline \multirow[t]{2}{*}{ Clutch positions subsequent to first. . } & Blastoderm & 148 & -.091 \\
\hline & Somites & 140 & .133 \\
\hline \multirow[t]{2}{*}{ Under inbreeding. } & Blastoderm & 70 & -.078 \\
\hline \multirow{2}{*}{\multicolumn{4}{|c|}{1940}} \\
\hline & & & \\
\hline \multirow[t]{2}{*}{ All clutch positions... } & Blastoderm & 52 & -.023 \\
\hline & Somites & 50 & .217 \\
\hline \multirow[t]{2}{*}{ 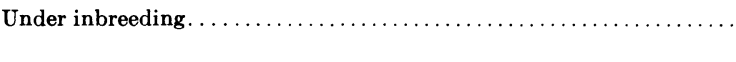 } & Blastoderm & 16 & -.197 \\
\hline & Somites & 16 & -.073 \\
\hline \multirow[t]{2}{*}{ First clutch position... } & Blastoderm & 31 & .258 \\
\hline & Somites & 26 & .302 \\
\hline \multirow[t]{2}{*}{ Under inbreeding. . } & Blastoderm & 12 & -.060 \\
\hline & Somites & 8 & -.031 \\
\hline \multirow{2}{*}{ Clutch positions subsequent to first. . } & Blastoderm & 52 & -.104 \\
\hline & Somites & 46 & .243 \\
\hline \multirow[t]{2}{*}{ Under inbreeding. . } & Blastoderm & 16 & -.081 \\
\hline & Somites & 16 & .150 \\
\hline \multicolumn{4}{|l|}{1941} \\
\hline \multirow[t]{2}{*}{ 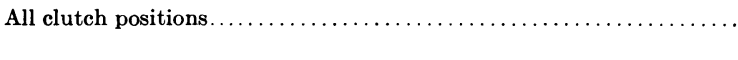 } & Blastoderm & 101 & .092 \\
\hline & Somites & 103 & .119 \\
\hline \multirow[t]{2}{*}{ Under inbreeding. . } & Blastoderm & 57 & .144 \\
\hline & Somites & 58 & .237 \\
\hline \multirow[t]{2}{*}{ First clutch position. . } & Blastoderm & 76 & -.154 \\
\hline & Somites & 79 & .083 \\
\hline \multirow[t]{2}{*}{ Under inbreeding. . } & Blastoderm & 42 & .111 \\
\hline & Somites & 48 & .136 \\
\hline \multirow[t]{2}{*}{ Clutch positions subsequent to first. . } & Blastoderm & 96 & -.044 \\
\hline & Somites & 94 & .029 \\
\hline \multirow[t]{2}{*}{ Ùnder inbreeding. ... } & Blastoderm & 54 & -.012 \\
\hline & Somites & 54 & .083 \\
\hline
\end{tabular}

* Significant at the $5 \%$ level.

† Significant at the $1 \%$ level.

in the oviduct longer than those occupying a subsequent clutch position, the correlation is .29 and still not significant. In eggs occupying clutch positions subsequent to the first and incubated for 38 hours, the correlation between mean number of somites and hatchability is .50 which is significant at $\mathrm{P}=.01$. Finally, in eggs occupying first clutch position and incubated for 38 hours, the correlation between mean number of somites and hatchability is .63 which 
is significant at $P=.05$. The older the embryos from a given mating, the higher the correlation observed between their mean size and hatchability in the same mating, so far as the OB females were concerned in 1940.

The positive and significant correlation coefficients, observed between mean early embryo size and hatchability in the $\mathrm{OB}$ origin of females in 1940, are interpreted as evidence that inbreeding resulted in homozygosity for deleterious genes in many of the zygotes produced by these OB females. These deleterious genes started expressing themselves shortly after fertilization and their outward manifestation was a retardation in embryonic development. The higher the frequency of deleterious genes in a particular mating, the larger the proportion of zygotes affected, the greater the average reduction

TABLE 70

ANALYSIS OF COVARIANCE OF EARLY EMBRYO SIZE AND HATCHABILITY IN INDIVIDUAL MATINGS OF

OB FEMALES IN 1940

\begin{tabular}{|c|c|c|c|}
\hline Clutch position & $\begin{array}{c}\text { Embryonic } \\
\text { stage }\end{array}$ & $\begin{array}{c}\text { Number } \\
\text { of matings }\end{array}$ & Correlation \\
\hline 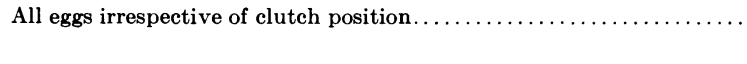 & $\begin{array}{l}\text { Blastoderm } \\
\text { Somites }\end{array}$ & $\begin{array}{l}30 \\
29\end{array}$ & $\begin{array}{l}.14 \\
.47\end{array}$ \\
\hline 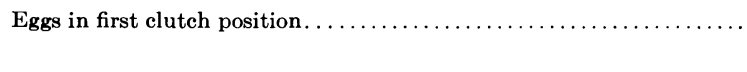 & $\begin{array}{l}\text { Blastoderm } \\
\text { Somites }\end{array}$ & $\begin{array}{l}15 \\
13\end{array}$ & $\begin{array}{l}.29 \\
.63^{*}\end{array}$ \\
\hline Eggs in clutch positions subsequent to the first.......... & $\begin{array}{l}\text { Blastoderm } \\
\text { Somites }\end{array}$ & $\begin{array}{l}30 \\
28\end{array}$ & $\begin{array}{l}.10 \\
.50 \dagger\end{array}$ \\
\hline
\end{tabular}

* Significant at the $5 \%$ level.

+ Significant at the $1 \%$ level.

in blastoderm size or number of somites and in the percentage of hatchability. Hence, there was here a significant positive correlation between mean early embryo size and hatchability.

\section{DISCUSSION}

Eggs in first and last clutch positions contain embryos comparatively more advanced in development at time of oviposition and do not hatch as well as eggs occupying clutch positions intermediate to the first and the last. Eggs laid early in the morning and late in the afternoon contain embryos comparatively more and less advanced in development respectively and do not hatch as well as eggs laid in the later part of the morning and early part of the afternoon. Eggs with long time intervals contain embryos more advanced in development at time of oviposition and do not hatch as well as eggs with time intervals between 23 and 27 hours. On the other hand, eggs with abnormally short time intervals contain embryos comparatively less advanced in development and do not hatch as well as eggs with time intervals varying between 23 and 27 hours. These observations point towards a curvilinear relation between early embryo size and hatchability. MeNally and Byerly (1936) have previously drawn attention to the curvilinear relation between early embryo size and hatchability. They observed an increase in hatchability as the mean 
number of somites, after 48 hours of incubation, increased from 14 to 20 , and a rapid decrease in hatchability as the number of somites increased from 20 to 23. The existence of a curvilinear relation between early embryo size and hatchability is also supported by the observations of Taylor and Gunns $(1935,1939)$ who could not detect any significant difference in mean blastoderm diameter between the eggs of hens with poor, medium and high levels of hatchability. Taylor and Gunns (1939) have, however, observed a positive relation between extent of overgrowth in the unincubated blastoderm and hatchability, a relation which approached significance, but was not high enough for purposes of accurate prediction of individual hatchability.

In the data gathered in the present investigations the correlation observed between blastoderm diameter and hatchability was not significant (.04) but the correlation between number of somites and hatchability reached a level of significance (.18). Under inbreeding the correlation between number of somites and hatchability reached a higher level and was still significant (.24). This observation led to the analysis of the covariance of early embryo size and hatchability in the OB origin of birds used in 1940. In this instance the relationship between early embryo size and hatchability appeared to be linear and of increased magnitude as the embryos measured became older.

\section{SUMMARY}

Origin or genetic relationship and also systems of mating do not alter the general relationship observed between fertility and hatchability. Closely inbred matings of birds with an outbred origin show a negative correlation between fertility and hatchability which supports the view that fertility is distinct from hatchability.

The normal relation between early embryo size and hatchability appears to be curvilinear as demonstrated by the fact that eggs in first clutch position, laid early in the morning and with unusually long time intervals all contain embryos relatively more advanced in development, while eggs with short time intervals and laid late in the afternoon contain embryos relatively less advanced in development; but that all of these classes of eggs do not hatch as well as those in intermediate clutch position, laid in the middle part of the day, and with a time interval of 23 to 27 hours.

Following close inbreeding of birds with an outbred origin, the relationship between early embryo size and hatchability is linear and increases in magnitude and significance as the embryos measured become older. 


\section{LITERATURE CITED}

American Societry of Animal Production

1940. Report of committee on investigations. Proc. 33d Annual Meeting of the American Society of Animal Production, Chicago: 378.

AT'WOOD, HoRACE W.

1929. A study of the time factor in egg production. W. Va. Agr. Expt. Sta. Bul. 223:310 .

BERG, LAWRENCE R.

1945. The relationship of elutch position and time interval between eggs to eggshell quality. Poultry Sci. 24:555-563.

Blunn, Cecil Thomas

1934. The relation of adult body size to the rate of cell proliferation in the chicken embryo. Berkeley, California. 32 p. University of California, Thesis (Ph.D).

Blunn, Cecil Thomas, and Paul W. Gregory

1935. The embryological basis of size inheritance in the chicken. Jour. Expt. Zool. 70: $397-414$.

BLYTH, JANET S.

1945. Infertility and embryonic mortality in the domestic fowl. Roy. Soc. Edinb., Proc. $62 \mathrm{~B}(2: 23): 191-201$.

BRONKHORST, J. J.

1933. A physical, chemical and physiological study of high and low hatehing lines of single comb White Leghorns. Ithaca, New York. 110 p. Cornell University, Thesis (Ph.D.).

BYerLy, THEODORE C.

1930. The effects of breed on the growth of the chick embryo. Jour. Morph. and Physiol. $50: 341-359$.

1931. Time of occurrence and probable causes of mortality in chick embryos. London, England. Proc. 4th World's Poultry Congress, 1930, Section A :174-181.

1932. Growth of the chick embryo in relation to its food supply. Jour. Expt. Biol. 9: $15-44$.

1934. Some factors affecting the length of the incubation period. Atti del V cong. mond. di pollicoltura, Roma, 1933, 2:373-379.

Byerly, Theodore C., G. W. Helsel and J. P. QuinN

1938. Growth in weight and cell number. Genetic effects in the chick embryo and chick. Jour. Expt. Zool. 78:185-203.

Byerly, Theodore C., C. W. KNox and M. A. JULL.

1934. Some genetic aspects of hatchability. Poultry Sci. 13:230-238.

Byerly, Theodore C., H. W. Titus and N. R. Ellis

1933. Effect of diet on egg composition. II. Mortality of embryos in eggs from hens on diets containing protein supplements of different origin. Jour. Nutr. 6:225-242.

Cole, Leon J., and J. G. HALPIN

1916. Preliminary report of results of an experiment on close inbreeding in fowls. Jour. Amer. Assoc. of Instr. and Invest. in Poultry Husbandry 3:7-8.

1922. Results of eight years of inbreeding Rhode Island Reds. Anat. Rec. $23: 97$.

DERRICK, G. ETHEL

1937. An analysis of the early development of the chick by means of the mitotic index. Jour. Morph. 61:257-284.

DRYDEN, JAMES

1915. Inbreeding, its effects on vigor and egg laying. Jour. Amer. Assoc. of Instr. and Invest. in Poultry Husbandry 1:19.

1916. Poultry Breeding and Management. 402 p. New York. Orange Judd Company. Dumon, A. G.

1931. The effects of inbreeding on hatchability. London, England. Proc. 4th World's Poultry Congress, 1930, Section A:1-5. 
DUNKERLEY, J. S.

1931. The effect of inbreeding. London, England. Proc. 4th World's Poultry Congress Section A:46-72.

DunN, L. C.

1923. Experiments on close inbreeding in fowls. Connecticut (Storrs) Agr. Expt. Sta. Bul. 111:139-172.

1928. The effect of inbreeding and crossbreeding on fowls. Berlin. Verhandl. d. V Intern. Kongr. f. Vererbungswissenschaft:609-617.

Fischel, Alfred

1896. Über Variabilität und Wachstum des embryonalen Körpers. Morph. Jahrbuch $24: 369-404$.

Fronda, F. M.

1925. Some observations on the body temperature of poultry. Cornell Vet. 15:8-20.

FUnK, E. M.

1934. Factors influencing hatchability in the domestic fowl. Mo. Agr. Expt. Sta. Bul. $341: 3-22$.

1939. The relation of size of clutch and position of the egg in the clutch to hatching results. Poultry Sci. 18:350-353.

GOODALE, HubERT D.

1927. Six consecutive generations of brother to sister matings in White Leghorns. A preliminary report on studies in inbreeding in poultry. Poultry Sci. 6:274-276.

Hays, F. A.

1924. Inbreeding Rhode Island Red fowls with special reference to egg production. Amer. Nat. $58: 43-59$.

1926. The relation of the male to hatchability of hen's eggs. Sci. $64: 408$.

1929. Inbreeding in relation to egg production. Mass. Agr. Expt. Sta. Bul. 258:256-302.

1936. Time interval between eggs of Rhode Island Red pullets. Jour. Agr. Res. 52:633638.

1938. Time interval between clutches in Rhode Island Red pullets. Jour. Agr. Res. 57: 575-581.

Hays, F. A., and C. Nicolaides

1934. Variability in development of fresh-laid hen eggs. Poultry Sci. 13:74-90.

Hays, F. A., and RUBY SANBoRN

1924. The inheritance of fertility and hatchability in poultry. Mass. Agr. Expt. Sta. Tech. Bul. 6:20-42.

Henderson, EARL W.

1930. Growth and development. XVI. The influence of temperature and breeding upon the rate of growth of chick embryos. Mo. Agr. Expt. Sta. Res. Bul. 149:5-47.

HENDRICKS, WALTER A.

1935. The statistical treatment of hatchability data. Poultry Sci. 14:365-372.

HuTT, F. B., and A. W. GREENWOOD

1929. Studies in embryonic mortality in the fowl. III. Chick monsters in relation to embryonic mortality. Roy. Soc. Edingb., Proc. 49:145-155.

HutT, F. B., and A. M. PILKey

1930. Studies in embryonic mortality in the fowl. IV. Comparative mortality rates in eggs laid at different periods of the day and their bearing on theories of the origin of monsters. Poultry Sci. 9:194-203.

Hyre, H. M., and G. O. HALL

1932. The constancy of hatehing power in hens. Poultry Sci. 11:166-171.

Jull, MORLEy A.

1928. Studies in hatchability. I. Hatchability in relation to antecedent egg production, fertility, and chick mortality. Poultry Sci. 7:195-215. 
1929a. Studies in hatchability. II. Hatchability in relation to the consanguinity of the breeding stock. Poultry Sci. 8:219-229.

1929b. Studies in hatchability. III. Hatchability in relation to coefficients of inbreeding. Poultry Sci. $8: 361-368$.

1930. Studies in hatchability. IV. The effects of intercrossing inbred strains of chickens on fertility and hatchability. Poultry Sci. 9:149-156.

1931. Studies in hatchability. V. The inheritance of hatchability. London, England. Proc. 4th World's Poultry Congress, 1930, Section A:167-173.

1933. Inbreeding and intercrossing in poultry. Jour. Hered. 24:93-101.

1935. Studies in fertility in the domestic fowl. Poultry Sci. 14:37-41.

1940. Poultry Breeding. 2d edition. 484 p. John Wiley and Sons, New York.

KaUFMaN, LAURA

1927. Recherches sur la eroissance du corps et des organes du pigeon. Biol. Gen. 3:105128.

1929. Les différences du taux d'accroissement des oiseaux sont-elles manifestes pendant la vie embryonnaire. Arch. d'Anat. Micros. 25:325-335.

$1930 a$. Researches on the phaenogenesis of the differences of body-size, partly grounded on a new method of in vitro cultures of fowl and pigeon eggs. Acta Biol. Expt. (Varsovie) $5: 33-46$.

1930b. L'origine des différences de la taille du corps des oiseaux. C. R. Assoc. Anatomistes. 25ème réunion, Amsterdam. (21) :183-188.

1930c. Innere und äussere Wachstumsfaktoren. Untersuchungen an Hühnern und Tauben. Arch. f. Entwickl. Mech. der Organ. 122:395-431.

1936. Die Entstehung von Unterschieden in der Körpergrösse bei Hühnern. Arch. Geflügelkunde 10:374-377.

Keibel, Franz

1904. Ueber den Entwickelungsgrad der Organe in den verschiedenen Stadien der embryonalen Entwicklung der Wirbeltiere. In Handbuch der vergleichenden und experimentellen Entwicklungslehre der Wirbeltiere, herausg. von Dr. Oskar Hertwig. $3(3: 9): 131-148$. Jena. Gustav Fischer.

Keibel, Franz, and K. Abraham

1900. Normaltafeln zur Entwicklungsgeschichte des Huhnes (Gallus domesticus). 132 p. Jena. Gustav Fischer.

KeLler, C.

1933. Vergleichende Zellen- und Kernmessungen bei grossen und kleinen Hühnerrassen zur Prüfung der genetisch bedingten Wuchsunterschiede. Ztschr. f. Zellforsch. u. Mikros. Anat. 19:510-536.

Knox, C. W.

1927. Correlation studies of certain characters upon hatchability and their interrelationships. Poultry Sci. $6: 110-117$.

1946. The development and use of chicken inbreds. Poultry Sci. 25:262-272.

LAMOREUX, W. F.

1940. The influence of intensity of egg production upon infertility in the domestic fowl. Jour. Agr. Res. 61:191-206.

LANDAUER, WALTER

1937. The hatchability of chicken eggs as influenced by environment and heredity. Conn. (Storrs) Agr. Expt. Sta. Bul. 216:5-84.

1941. The hatchability of chicken eggs as influenced by environment and heredity. Conn. (Storrs) Agr. Expt. Sta. Bul. $236: 5-124$.

LERNER, I. MichaEL

1937. Relative growth and hereditary size limitation in the domestic fowl. Hilgardia 10:511-560.

1944. Lethal and sublethal characters in farm animals. A checklist and proposed numbering system. Jour. of Hered. 35:219-224. 


\section{LeVI, GIUSEPPE}

1922. Per la migliore conoscenza del fundamento anatomico e dei fattori morfogenetici della grandezza del corpo. L'acerescimento dei somiti mesodermici e di altre individualità morfologiche. Archiv. ital. di Anat. e di Embriol. 18(Suppl.) :316-433.

1925. Wachstum und Körpergrösse. Die strukturelle Grundlage der Körpergrösse bei vollausgebildeten und im Wachstum begriffenen Tiere. Ergeb. der Anatomie und Entwicklungsgeschichte 26:87-342.

Lush, JAY L.

1945. Animal breeding plans. $3 \mathrm{~d}$ edition. 443 p. Ames, Iowa. The Collegiate Press.

MCNally, E. H., and Theodore C. ByerLy

1936. Variation in the development of embryos of hens' eggs. Poultry Sci. 15:280-283.

MEHNERT, ERNST

1896. Die individuelle Variation des Wirbelthierembryo. Morphologische Arbeiten (Schwalbe) 5:386-444.

Munro, SteErLing S.

1938. The effect of dilution and density on the fertilizing capacity of fowl sperm suspensions. Can. Jour. Res. Section D, 16:281-299.

1940. The relation of specific gravity to hatching power in eggs of the domestic fowl. Sci. Agr. 21:53-62.

1942. Further data on the relation between shell strength, potential hatchability and chick viability in the fowl. Sci. Agr. 22:698-704.

1946. Relative influence of heredity and environment on fertility and hatchability in Wyandottes. Empire Jour. Expt. Agr. 14:25-30.

Munro, Sterling S., and Igor L. Kosin

1945. Proof of the existence of pre-oviposital embryonic deaths in chickens and their bearing on the relation between 'fertility' and hatchability. Can. Jour. Res. Section D, $23: 129-138$.

NeEL, J. K.

1942. A calibration of the development of the chick under improved conditions of incubation and the relationship of developmental rate to age of hen and hatchability record. Poultry Sci. 21:294-300.

\section{Nicolaides, Costas}

1933. Relation of time of laying and embryonic mortality. Poultry Sci. 12:274-276.

Northern Sub-committee of the National Poultry Instimute Advisory Committee

1934. Experiments on inbreeding of poultry. G. Brit. Min. Agr. and Fisheries Bul. 83: 1-59.

OLSEN, M. W.

1942. Maturation, fertilization, and early cleavage in the hen's egg. Jour. Morph. 70 : 513-533.

Parker, Jesse E., F. F. McKenzie and H. L. Kempster

1942. Fertility in the male domestic fowl. Mo. Agr. Expt. Sta. Res. Bul. 347:3-50.

Patterson, C. F.

1930. Good morning eggs are best for hatching. Poultry Item. March 1930.

Pearl, Raymond, and F. M. Surface

1909. Data on certain factors influencing the fertility and hatching power of eggs. Maine Agr. Expt. Sta. Bul. 168:105-164.

PRICE, J. B.

1938. The embryology of the cormorant (Phalacrocorax penicillatus) during the period of somite formation. A comparison with the chick (Gallus domesticus) and the quail (Lophortyx californica). Amer. Jour. Anat. 63:409-447. 
PRITZKer, I. J.

1940. Difference in weight and hatehing capacity of eggs laid during different parts of the day. (Trans. title.) Proc. Lenin Acad. Agr. Sci. USSR (6) 41-44. [Cited after Landauer (1941).]

RENDEL, J. M.

1943. Variations in the weights of hatched and unhatched ducks' eggs. Biometrika 33 : $48-58$.

RENSCH, B.

1923. Über die Ursache von Riesen- und Zwergwuchs beim Haushuhn. Ztschr. indukt. Abstamm. u. Vererbungslehre 31:268-286.

RIDDLE, OSCAR

1923. On the cause of twinning and abnormal development in birds. Amer. Jour. Anat. $32: 199-252$.

SCHLEINITZ, GRÄFIN VON

1925. Experimente über nahe Inzucht beim Geflügel. Deutsche Landwirt. Geflügelzeitung 28. See also abst. in Internatl. Rev. Sci. and Pract. Agr. N.S. 4:909.

SCOTT, H. M., and DoN C. WARREN

1936. Influence of ovulation rate on the tendency of the fowl to produce eggs in clutches. Poultry Sci. 15:381-389.

Stockard, Charles R.

1921. Developmental rate and structural expression: an experimental study of twins, 'double monsters' and single deformities, and the interaction among embryonic organs during their origin and development. Amer. Jour. Anat. 28:115-277.

Sturkie, PaUl D., and A. G. Williams

1945. Studies on pregastrular development, early embryonic development, and hatchability of prematurely laid eggs of the hen. Poultry Sci. 24:546-554.

TAYlor, Lewis W., and C. A. Gunns

1935. Size of unincubated embryo in relation to hatchability. Poultry Sci. 14:294.

1939. Development of the unincubated chick embryo in relation to hatchability of the egg. Cleveland, Ohio. Proc. 7th World's Poultry Congress : 188-190.

Vecchi, Anita

1936. Osservazioni sugli effetti della consanguineità nelle selezione dei polli. Berlin and Leipzig. VI Weltgeflügelkongress. Kongressbericht 2:86-89.

W ARREN, DON C.

1927. Hybrid vigor in poultry. Poultry Sci. $7: 1-8$.

1934. The influence of some factors on the hatchability of the hen's egg. Kans. Agr. Expt. Sta. Tech. Bul. 37:5-42.

W ARREN, DON C., and H. M. SCOTT

1934. Ovulation in the domestic hen. Sci. $80: 461-462$.

1935a. The time factor in egg formation. Poultry Sci. 14:195-207.

$1935 b$. Physiological factors influencing the rate of egg formation in the domestic hen. Jour. Agr. Res. 51:565-572.

WATERS, NELSON F.

1932. Inbreeding in White Leghorn fowl. Ithaca, N.Y. Proc. 6th Inter. Congress Genetics 2:205-206.

1944. The hatchability of chicken eggs as influenced by diallel crossing. Poultry Sci. $23: 495-496$.

1945. The influence of inbreeding on hatchability. Poultry Sci. 24:329-334.

WATERs, Nelson F., and W. V. LAMBERT

1935. Ten years of inbreeding in the White Leghorn fowl. Poultry Sci. 14:296.

1936a. A ten-year inbreeding experiment in the domestic fowl. Poultry Sci. 15:207-218. 1936b. Inbreeding in the White Leghorn fowl. Iowa Agr. Expt. Sta. Res. Bul. 202:5-55.

1936c. Inbreeding in the White Leghorn fowl. Berlin and Leipzig. VI Weltgeflügelkongress. Kongressbericht 2:91-93. 
WiLson, W. O.

1948. Egg production rate and fertility in inbred chickens. Poultry Sei. 27:719-726.

WRIGHT, SEWALL

1922. Coefficients of inbreeding and relationship. Amer. Nat. 56:330-338.

1923. Mendelian analysis of the pure breeds of livestock. 1 . The measurement of inbreeding and relationship. Jour. Hered. 14:339-348. 
The journal Hilgardia is published at irregular intervals, in volumes of about 600 pages. The number of issues per volume varies.

Subscriptions are not sold. The periodical is sent as published only to libraries, or to institutions in foreign countries having publications to offer in exchange.

You may obtain a single copy of any issue free, as long as the supply lasts; please request by volume and issue number from:

\section{Publications Office \\ College of Agriculture \\ Berkeley 4, California}

The limit to nonresidents of California is $\mathbf{1 0}$ separate issues on a single order. A list of the issues still available will be sent on request. 